Rwanda: Staff Report for 2019 Article IV Consultation and a Request for a Three-Year Policy Coordination Instrument-Press Release; Staff Report; and Statement by the Executive Director for Rwanda 


\section{INTERNATIONAL MONETARY FUND}

\section{RWANDA}

IMF Country Report No. 19/211

July 2019

\section{STAFF REPORT FOR THE 2019 ARTICLE IV CONSULTATION AND REQUEST FOR A THREE-YEAR POLICY COORDINATION INSTRUMENT-PRESS RELEASE; STAFF REPORT; AND STATEMENT BY THE EXECUTIVE DIRECTOR FOR RWANDA}

In the context of the 2019 Article IV Consultation and a Request for a Three-Year Policy Coordination Instrument, the following documents have been released and are included in this package:

$-\square$ A Press Release.

- $\square$ The Staff Report for the 2019 Article IV Consultation and Request for a Three-Year Policy Coordination Instrument prepared by a staff team of the IMF for the Executive Board's consideration on June 28, 2019, following discussions that ended on March 22, 2019, with the officials of Rwanda on economic developments and policies underpinning the IMF arrangement under the 2019 Article IV Consultation and Policy Coordination Instrument. Based on information available at the time of these discussions, the staff report was completed on June 12, 2019.

- $\square$ A Debt Sustainability Analysis prepared by the International Monetary Fund (IMF) and the International Development Association (IDA) staffs.

- $\square$ An Informational Annex prepared by the IMF staff.

- $\square$ A Statement by the Executive Director for Rwanda.

The documents listed below have been or will be separately released:

Letter of Intent sent to the IMF by the authorities of Rwanda*

Program Statement by the authorities of Rwanda*

Technical Memorandum of Understanding*

The IMF's transparency policy allows for the deletion of market-sensitive information and premature disclosure of the authorities' policy intentions in published staff reports and other documents.

Copies of this report are available to the public from

International Monetary Fund $\bullet$ Publication Services

PO Box 92780 • Washington, D.C. 20090

Telephone: (202) 623-7430 • Fax: (202) 623-7201

E-mail: publications@imf.org Web: http://www.imf.org

Price: $\$ 18.00$ per printed copy

\section{International Monetary Fund Washington, D.C.}

(c) 2019 International Monetary Fund

CInternational Monetary Fund. Not for Redistribution 
Press Release No. 19/258

FOR IMMEDIATE RELEASE

June 28, 2019
International Monetary Fund

$70019^{\text {th }}$ Street, NW

Washington, D. C. 20431 USA $\square$

\section{IMF Executive Board Concludes the 2019 Article IV Consultation and Request for a Three-Year Policy Coordination Instrument with Rwanda}

On June 28, 2019, the Executive Board of the International Monetary Fund (IMF) concluded the Article IV consultation and approved a new Three-Year Policy Coordination Instrument (PCI) with Rwanda. ${ }^{1}$

Rwanda continues to make notable progress in sustaining high and inclusive growth. Rwanda's National Strategy for Transformation (NST) aims to make progress toward the SDGs, but its financing will be challenging.

The newly-approved PCI-supported program will build on the successes of Rwanda's previous programs with the IMF. The program aims to support NST implementation, including through an eased fiscal policy stance and additional domestic resource mobilization, while also maintaining external and debt sustainability. Program reviews will take place on a semi-annual fixed schedule. While the PCI involves no use of IMF financial resources, successful completion of program reviews will help signal Rwanda's commitment to continued strong macroeconomic policies and structural reforms.

Following the Executive Board's discussion on Rwanda, Tao Zhang, Deputy Managing Director and Acting Chair, issued the following statement:

"Rwanda has made notable progress in reaching its development objectives. Rapid and inclusive growth has been based on a combination of strategic goal-setting, public accountability, and broad ownership of policies. This was supported by strong macroeconomic performance and rapid responses to shocks, for example, the recent exchange rate adjustment that helped align the external position with fundamentals.

"Growth in 2018 was stronger than expected, at 8.6 percent, led by construction and services. Growth should remain around 8 percent in 2019, supported by public investment spending,

\footnotetext{
${ }^{1}$ Under Article IV of the IMF's Articles of Agreement, the IMF holds bilateral discussions with members, usually every year. A staff team visits the country, collects economic and financial information, and discusses with officials the country's economic developments and policies. On return to headquarters, the staff prepares a report, which forms the basis for discussion by the Executive Board.
} 
private investment, and interventions aimed at promoting diversified and higher value-added economic activity. Inflation has been below the authorities' targeted band for several months, prompting the central bank to lower its policy rate in May.

“The new PCI-supported program supports Rwanda's National Strategy for Transformation (NST), while safeguarding external and debt sustainability. An eased medium-term fiscal stance will provide more room for priority investments, while keeping debt risks low. NST implementation will also be supported by measures to mobilize domestic revenues and to further strengthen public financial management.

"The central bank has made good progress in implementing its new forward-looking, interest rate-based operational framework. Short-term interest rates convergence and the nascent monetary transmission to longer-term interest rates should be further reinforced through continued active liquidity management, deeper money markets, and enhanced communications of policy intentions.

"Going forward, the NST aims to make progress toward the Sustainable Development Goals and help crowd in the private sector as an engine for growth. However, financing the strategy will be challenging. Initiatives such as the African Continental Free Trade Area and the Compact with Africa should help leverage additional private financing."

\section{Recent Economic Developments}

Rwanda has achieved notable success in reaching its development objectives. A combination of strategic goal-setting, public accountability, and broad ownership of policies has helped the country emerge from fragility as one of the fastest-growing economies in SSA and the world. Moreover, growth has been inclusive, and extensive investment in social safety nets has reduced poverty significantly.

The economic outlook remains positive. Real GDP growth reached 8.6 percent $y-0-y$ in 2018 supported by activity in construction and services. Composite indicators suggest a continued trend in early 2019. Projections over the next five years have been revised up, to around 8.0 percent, based on first round effects of higher public investment spending agreed under the macroeconomic framework. Inflation is expected to rise in the second half of 2019 and remain thereafter within the target band also supported by policy easing by the National Bank of Rwanda. The current account deficit is expected to increase in 2019-20, due to airport construction, and decline thereafter.

Rwanda's economic outlook is subject to balanced risks. Acceleration of several large public and private ongoing investment projects (including peat power plant, tin smelting factory, new energy distribution substations and construction of new Special Economic Zones) and their potential impact on productivity, as well as enhanced regional trade ties, pose upside risks to growth. Potential downside risks include lower than expected ODA, variable weather/climate change, commodity price movements, and regional security issues. 


\section{Program Summary}

The program is designed to support implementation of the National Strategy for Transformation, while maintaining macroeconomic stability. The program consists of four main pillars: (1) recalibrating fiscal objectives and the medium-term fiscal stance; (2) bolstering domestic revenues over the medium term; (3) improving public financial management, notably fiscal risk management and transparency; and (4) supporting the new monetary policy framework, including through financial sector development.

The National Bank of Rwanda (BNR) continues its efforts to ensure successful implementation of the new interest rate-based monetary policy operational framework. These include commitments to strengthen communication and further deepen money markets, including by strengthening the repo market, to strengthen monetary policy transmission and enhance credibility of the new framework.

Structural reforms focus on supporting the National strategy and Transformation policies including by bolstering long-term savings, upgrading the national payments system and introducing new platforms for broader participation in the government securities market and more interaction across types of financial services providers. Rwanda's ambitions for Vision 2050 and SDG achievement will also be supported by a renewed focus on the quality of education and private sector-led growth.

\section{Executive Board Assessment ${ }^{2}$}

Directors commended the authorities' effective use of strategic goal-setting, public accountability, and broad ownership of policies to bring about rapid and inclusive growth, and significant progress toward their development objectives. Directors agreed that a PCI will appropriately support the authorities' efforts to build on their progress. They highlighted the importance of continued strong ownership of the reform agenda, as well as strong donor support and capacity building.

Directors welcomed the new program's focus on supporting Rwanda's National Strategy for Transformation (NST), aimed at accelerating the achievement of the country's development goals. They supported recalibrating the medium-term fiscal stance to provide more room for priority capital investment and social spending while maintaining a low risk of debt distress, with some Directors stressing the importance of consistency with the EAC fiscal deficit convergence. Directors emphasized the importance of domestic resource mobilization, including streamlining tax exemptions, strengthening tax policy capacity, and developing a medium-term revenue strategy. They welcomed the authorities' commitment to further

\footnotetext{
${ }^{2}$ At the conclusion of the discussion, the Managing Director, as Chairman of the Board, summarizes the views of Executive Directors, and this summary is transmitted to the country's authorities. An explanation of any qualifiers used in summings up can be found here: http://www.imf.org/external $/ \mathrm{np} / \mathrm{sec} / \mathrm{misc} /$ qualifiers.htm.
} 
strengthen public financial management by identifying and mitigating potential fiscal risks and further enhancing fiscal transparency.

Directors agreed that Rwanda's new monetary policy operational framework is appropriate and welcomed the recent easing aimed at bringing inflation back within the target range. They took positive note of the central bank's active policy operations that have led to a convergence of money market and policy rates and welcomed the nascent transmission of policy to longer-term rates. Directors emphasized that the authorities' commitment to a more flexible exchange rate regime, combined with improved liquidity management, forecasting, and communication, would further strengthen monetary policy transmission.

Directors welcomed the NST's focus to increase reliance on the private sector as an engine of growth and job creation and highlighted the supportive measures to bolster financial development and mobilize national savings and improve education. Noting Rwanda's inherent challenges in attracting private investment, they welcomed the African Continental Free Trade Area as a means for creating larger markets. They saw initiatives such as the G-20 Compact with Africa, together with aid directed toward blended finance, as vehicles to leverage additional private financing. 


\begin{tabular}{|c|c|c|c|c|c|c|c|}
\hline & 2017 & 2018 & 2019 & 2020 & 2021 & 2022 & 2023 \\
\hline & Act. & Prel. & Proj. & Proj. & Proj. & Proj. & Proj. \\
\hline \multicolumn{8}{|c|}{ (Annual percentage change, unless otherwise indicated) } \\
\hline \multicolumn{8}{|l|}{ Output and prices } \\
\hline Real GDP & 6.1 & 8.6 & 7.8 & 8.1 & 8.2 & 8.0 & 7.5 \\
\hline GDP deflator & 7.3 & -0.8 & 4.2 & 5.0 & 5.0 & 5.0 & 5.0 \\
\hline CPI (period average) & 4.8 & 1.4 & 3.5 & 5.0 & 5.0 & 5.0 & 5.0 \\
\hline CPI (end period) & 0.7 & 1.1 & 5.0 & 5.0 & 5.0 & 5.0 & 5.0 \\
\hline Terms of trade (deterioration, -) & 1.8 & -0.7 & 0.7 & 0.1 & 0.2 & 0.4 & 0.9 \\
\hline \multicolumn{8}{|l|}{ Money and credit } \\
\hline Broad money (M3) & 12.4 & 15.6 & 19.8 & 20.0 & 17.7 & 16.9 & 15.9 \\
\hline Reserve money & 8.8 & 16.1 & 17.2 & 17.9 & 15.7 & 14.9 & 14.2 \\
\hline Credit to non-government sector & 13.9 & 10.8 & 12.8 & 14.3 & 13.9 & 13.3 & 13.4 \\
\hline M3/GDP (percent) & 23.6 & 25.3 & 27.0 & 28.5 & 29.5 & 30.5 & 31.3 \\
\hline NPLs (percent of total gross loans) & 7.6 & 6.4 & $\ldots$ & $\ldots$ & $\ldots$ & $\ldots$ & $\ldots$ \\
\hline Budgetary central government & \multicolumn{5}{|c|}{ (Percent of GDP, unless otherwise indicated) } & & \\
\hline Total revenue and grants & 22.9 & 24.1 & 23.1 & 22.2 & 21.6 & 22.0 & 22.2 \\
\hline of which: tax revenue & 15.5 & 16.2 & 16.1 & 16.3 & 16.1 & 16.5 & 16.8 \\
\hline of which: grants & 4.7 & 4.9 & 4.8 & 3.9 & 3.4 & 3.6 & 3.7 \\
\hline Expenditure & 27.5 & 28.8 & 29.2 & 28.6 & 27.8 & 27.1 & 27.0 \\
\hline Current & 14.7 & 15.3 & 14.7 & 13.9 & 13.7 & 13.6 & 13.4 \\
\hline Capital & 10.7 & 11.5 & 12.0 & 12.3 & 12.1 & 11.5 & 11.8 \\
\hline Primary balance & -3.6 & -3.5 & -4.9 & -5.0 & -4.8 & -3.6 & -3.6 \\
\hline Overall balance & -4.7 & -4.7 & -6.1 & -6.4 & -6.2 & -5.1 & -4.8 \\
\hline excluding grants & -9.4 & -9.6 & -10.9 & -10.4 & -9.6 & -8.7 & -8.5 \\
\hline Net domestic borrowing & 0.2 & 0.0 & 2.0 & 0.8 & 1.1 & -0.3 & -0.6 \\
\hline \multicolumn{8}{|l|}{ Public debt } \\
\hline Total public debt incl. guarantees & 48.9 & 53.1 & 55.8 & 57.3 & 58.2 & 57.2 & 56.7 \\
\hline of which: external public debt & 37.9 & 41.6 & 43.4 & 44.6 & 45.5 & 45.6 & 45.8 \\
\hline PV of total public debt incl. guarantees & $\ldots$ & 41.1 & 42.5 & 42.9 & 42.7 & 41.6 & 41.2 \\
\hline \multicolumn{8}{|l|}{ Investment and savings } \\
\hline Investment & 23.8 & 24.4 & 27.7 & 28.4 & 28.2 & 27.6 & 27.8 \\
\hline Government & 10.7 & 11.5 & 12.0 & 12.3 & 12.1 & 11.5 & 11.8 \\
\hline Nongovernment & 13.1 & 12.9 & 15.7 & 16.1 & 16.1 & 16.1 & 16.1 \\
\hline Savings & 11.9 & 12.9 & 14.6 & 16.4 & 18.0 & 17.0 & 18.4 \\
\hline Government & 3.4 & 4.0 & 3.6 & 4.3 & 4.5 & 4.8 & 5.2 \\
\hline Nongovernment & 8.5 & 8.9 & 11.1 & 12.1 & 13.5 & 12.3 & 13.2 \\
\hline \multicolumn{8}{|l|}{ External sector } \\
\hline Exports (goods and services) & 21.7 & 21.4 & 21.2 & 21.4 & 22.1 & 22.1 & 22.7 \\
\hline Imports (goods and services) & 32.5 & 32.7 & 33.6 & 32.8 & 31.8 & 32.0 & 31.7 \\
\hline Current account balance (incl grants) & -7.8 & -7.9 & -9.6 & -9.4 & -7.9 & -8.1 & -7.4 \\
\hline Current account balance (excl grants) & -11.9 & -11.5 & -13.1 & -12.0 & -10.2 & -10.6 & -9.4 \\
\hline Current account balance (excl. large projects) & -7.4 & -7.4 & -9.0 & -8.3 & -7.4 & $\ldots$ & $\ldots$ \\
\hline \multicolumn{8}{|l|}{ Gross international reserves } \\
\hline In millions of US\$ & 1,163 & 1,319 & 1,428 & 1,566 & 1,637 & 1,726 & 1,867 \\
\hline In months of next year's imports & 4.5 & 4.6 & 4.7 & 4.9 & 4.7 & 4.5 & 4.5 \\
\hline \multicolumn{8}{|l|}{ Memorandum items: } \\
\hline \multicolumn{8}{|l|}{ GDP at current market prices } \\
\hline Rwanda francs (billion) & 7,600 & 8,189 & 9,199 & 10,442 & 11,866 & 13,460 & 15,197 \\
\hline US\$ (million) & 9,140 & 9,510 & $\ldots$ & $\ldots$ & $\ldots$ & $\ldots$ & $\ldots$ \\
\hline GDP per capita (US\$) & 774 & 787 & $\ldots$ & $\ldots$ & $\ldots$ & $\ldots$ & $\ldots$ \\
\hline Population (million) & 11.8 & 12.1 & 12.4 & 12.7 & 13.0 & 13.3 & 13.6 \\
\hline
\end{tabular}




\section{INTERNATIONAL MONETARY FUND}

June 12, 2019

\section{RWANDA}

STAFF REPORT FOR THE 2019 ARTICLE IV CONSULTATION AND REQUEST FOR A THREE-YEAR POLICY COORDINATION INSTRUMENT

\section{KEY ISSUES}

Context: Rwanda has made considerable progress in sustaining high and inclusive growth and reducing poverty. Despite numerous shocks, macroeconomic management has been strong and debt risks have remained low. Going forward, the authorities' National Strategy for Transformation (NST) aims to make progress toward the SDGs, but its financing will be challenging. A more neutral medium-term fiscal policy stance can help, reinforced with commitments for more domestic revenue mobilization and mitigation of fiscal risks. The central bank moved to a new interest-rate based monetary policy framework and, with inflation below its target range, eased the policy stance. To support their policies and NST implementation, the authorities are requesting approval of a 3-year program supported by the Policy Coordination Instrument ( $\mathrm{PCl})$.

\section{Main Policy Commitments}

Fiscal policy: A fiscal policy stance that accommodates spending to support NST implementation, while maintaining low debt risks. Commitments to increase domestic revenue mobilization will also support the NST. PFM reforms will identify and mitigate potential fiscal risks, continue to improve fiscal transparency.

Monetary policy: Under its new monetary policy framework, the central bank eased the policy stance to bring inflation back within its targeted range and steer inflation expectations. Reforms should continue to strengthen the transmission mechanism, deepen financial and capital markets, and improve access to financial services.

Structural reforms: The authorities' NST lays out a rich structural reform agenda to meet development goals. However, financing will be challenging, and the authorities continue to seek innovative approaches in their drive for results.

Risks: Risks to the program are low given Rwanda's impressive track record under successive IMF programs. Risks to the growth outlook are balanced.

Staff support the authorities' request for a three-year $\mathrm{PCl}$-supported program. 
Approved By

Zeine Zeidane (AFR)

and Yan Sun (SPR)
Discussions were held in Kigali during March 11-22, 2019. The mission comprised L. Redifer (head), E. Alper, T. McGregor, X. Fang (all AFR), S. Kaihatsu (SPR), V. Duarte Lledo (FAD), assisted by J. Bouhga-Hagbe (IMF/AFR Resident Representative in Kigali Office).

L. Nankunda (OED) also attended mission meetings. T. Gursoy and F. Morán Arce (both AFR) also contributed to this report.

\section{CONTENTS}

A. Fiscal Policy and Debt Sustainability: Advancing NST Implementation

B. Monetary Policy: Strengthening the Operational Framework and Developing the Financial Sector

C. Structural Policies: Encouraging the Private Sector

PROGRAM MODALITIES AND RISKS

STAFF APPRAISAL

BOXES

1. National Strategy for Transformation (NST)

2. Growth in Rwanda

3. Proposed Changes in Rwanda's Fiscal Framework

4. Domestic Revenue Mobilization

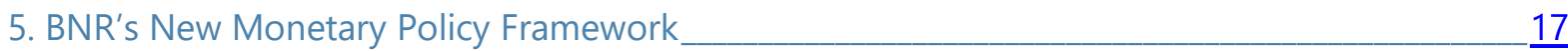

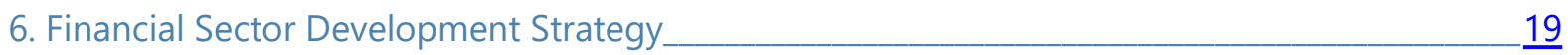

7. Selected Additional Public Interventions to Bolster Growth and Employment______ 20

\section{FIGURES}

1. Human Development Indicators in Rwanda

2. Selected Development Gains in Rwanda

3. Overview of Recent Economic Developments

4. Fiscal Developments

5. Monetary Developments

6. External Developments $\underline{26}$ 


\section{TABLES}

1. Selected Economic Indicators, 2017-23

2a. Budgetary Central Government Statement of Operations, GFSM 2014 Presentation, 2016/1722/23 (Billions of Rwandan francs)

2b. Budgetary Central Government Statement of Operations, GFSM 2014 Presentation, 2016/1722/23 (Percent of GDP)

2c. Budgetary Central Government Flows, FY16/17-22/23 (Billions of Rwandan francs $\underline{30}$

2d. Budgetary Central Government Flows, FY16/17-22/23 (Percent of GDP). $\underline{31}$

3. Monetary Survey, 2017-20

4. Balance of Payments, 2017-23

$\underline{33}$

5. Financial Soundness Indicators: December 2015-December 2018

34

6. Schedule of Reviews Under the Policy Coordination Instrument, 2019-22

$\underline{35}$

\section{ANNEXES}

I. Implementation of Key Policy Recommendations from the 2017 Article IV Consultation $\underline{36}$

II. Spending Needs for Reaching the SDG Goals 37

III. Risk Assessment Matrix $\underline{46}$

IV. External Sector Assessment $-\frac{47}{51}$

V. Capacity Development Strategy for FY2020

51

\section{APPENDIX}

I. Letter of Intent

Attachments

I. Program Statement $-\frac{54}{63}$

II. Technical Memorandum of Understanding 


\section{CONTEXT}

1. Rwanda's high growth has raised income levels and reduced poverty, but incomes and labor skills are still catching up to peers (Figures 1 and 2). As a result of very rapid growth over the past 25 years, per capita income has tripled. However, Rwanda's income levels remain below the average for Low-Income Countries (LICs). Nonetheless, high levels of public investment have been well used; as Human Development Indicators suggest better outcomes than peers in most areas. Notably, however, education outcomes lag. A rich development agenda and decisive reforms have resulted in impressive gains, with Rwanda scoring highly in several metrics, e.g.: WEF rank \#4 globally for gender inclusion, CPIA score of 4.0 (highest in SSA), and SSA rank \#2 for WB Doing Business.

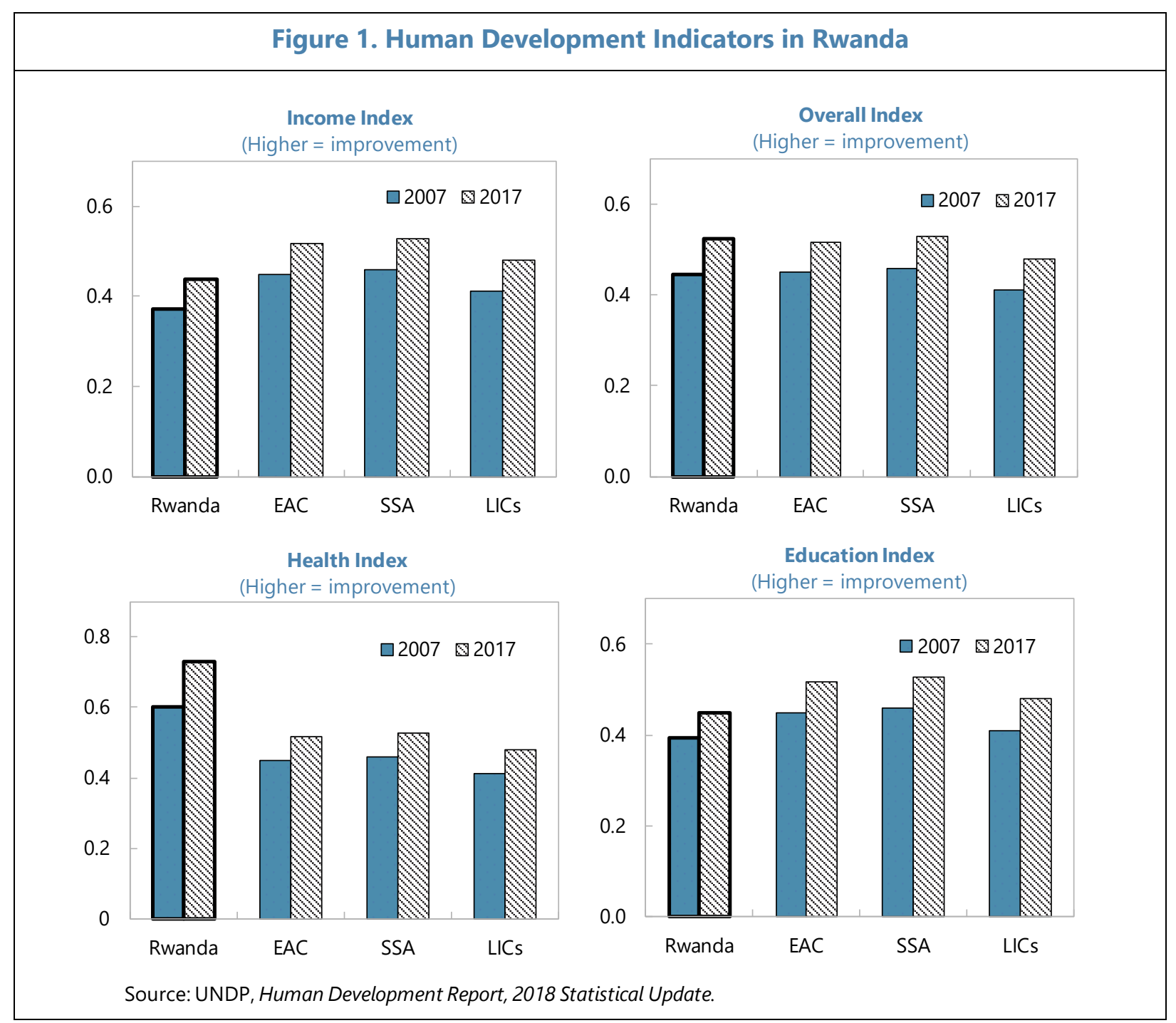


Figure 2. Selected Development Gains in Rwanda

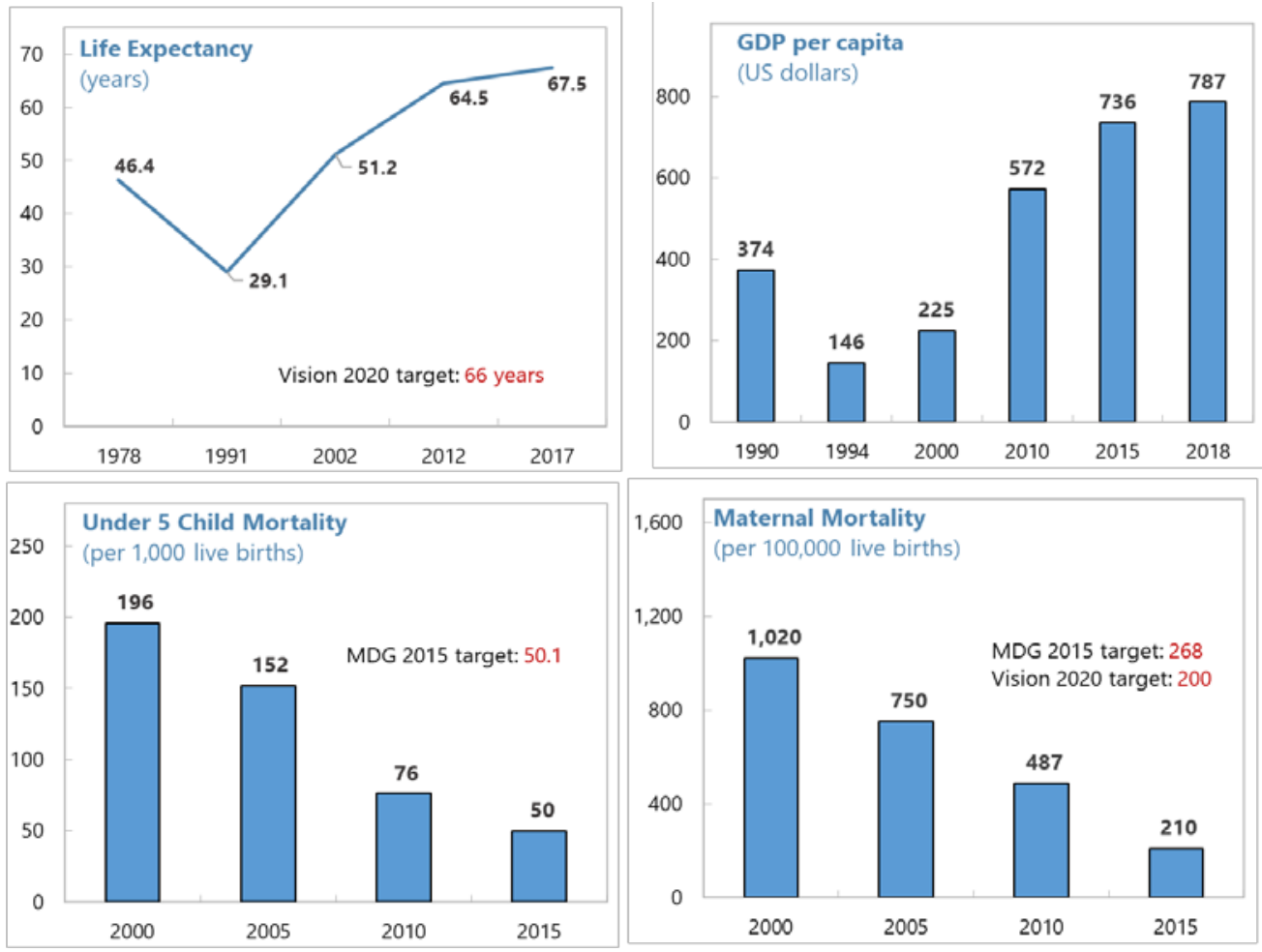

Sources: EICV 5 Report (NISR) and 2018 HDR Statistical Update (UNDP), 2015 Demographic Health Survey (NISR).

2. Rwanda has a strong track record of macroeconomic performance. Performance under the previous program was strong, and 2017 Article IV recommendations were largely addressed (Annex I). Despite scaling up of public investment, careful spending and domestic revenue gains have enabled the country to maintain a low risk of debt distress. The authorities have also shown nimble policy responses to shocks. For example, Rwanda's external position, reserves, and exchange rate came under pressure in 2015 following an adverse commodity price shock. To restore external sustainability, significant exchange rate adjustment and prudent fiscal and monetary policies were combined with policies to diversify exports. These were successful in reversing growing external imbalances.
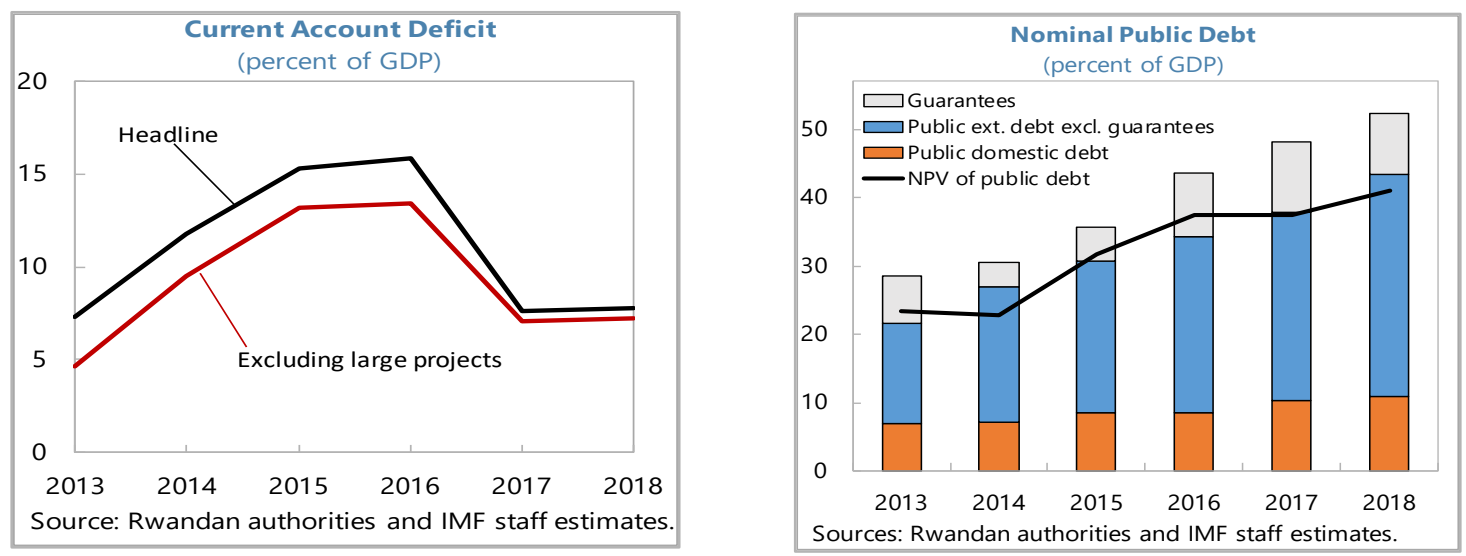
3. Rwanda has crafted a well-articulated development strategy designed to meet the Sustainable Development Goals (SDG), but financing will be a challenge. The authorities' "Vision 2050" strategy is aimed to achieve middle income status by 2035 and high-income status by 2050. The Vision is initially being implemented with a 7-year "National Strategy for Transformation" (NST), detailing sectoral strategies calibrated for SDG achievement (Box 1). An SDG costing case study undertaken by staff estimates that additional annual spending needs would be substantial to reach outcomes comparable to the highest performing peers in selected sectors (Annex II). For Rwanda, financing will be challenging: private investment is picking up, but official development assistance (ODA) is trending down and the scope is limited to improve domestic revenues and expenditure efficiency further.

\section{Box 1. National Strategy for Transformation (NST)}

Rwanda's Vision 2020 was devised in 2000 and was the roadmap for the development progress the country has achieved to date. In 2017, the government began to develop Vision 2050, an even more ambitious roadmap, aimed to achieve upper middle-income status by 2035 and high-income status by 2050.

Vision 2050 is to be operationalized by a series of more detailed development strategies, starting with the "National Strategy of Transformation" (NST). The 7-year NST-1 aims to transform the economy, society, and government into that of a higher-income country. The three transformation pillars are underpinned by a series of detailed and costed sectoral strategies that, among other things, aim to achieve a "domesticated" version of the SDGs.

The "economic transformation" pillar aims to accelerate inclusive growth and development founded on the private sector, knowledge and Rwanda's natural resources. It builds on the successes of the Vision 2020 in boosting productivity in agriculture, industry, and services. Looking forward, the NST1 prioritizes:

- Creating new jobs, via promoting new investment, bolstering domestic production, and STEM and vocational training;

- Managing land and urbanization, including upgrading Kigali's infrastructure and developing secondary cities;

- Improving education quality, with a focus on technical, and ICT skills, including through investment at all levels;

- Shifting the production and export base to higher value-added goods and services, via creating growth-enhancing infrastructure and strategic public interventions;

- Increasing domestic savings and expanding financial services access and depth, via interventions discussed in Box 5; and

- Improving agricultural productivity, via training; irrigation; pesticides; crop rotation; linking farmers, cooperatives, and markets; access to financial services and insurance; and promoting agribusiness and horticulture.

The social and governance transformation pillars are also specified, with goals to eradicate extreme poverty and malnutrition, improve the quality of education and health, build capable and accountable public institutions, ensure continued citizen participation and engagement in development strategies, continue international development cooperation, and ensuring security and safety, as well as justice, law and order.

NST-1 also stipulates cross-cutting interventions in: capacity development; HIV/AIDS and noncommunicable diseases; disability and social inclusion; climate change; regional integration; gender; and disaster management. 


\section{RECENT DEVELOPMENTS, OUTLOOK, AND RISKS}

4. 2018 growth was strong (Figure 3, Table 1).

Real GDP rose by 8.6 percent in 2018 , well beyond 7.2 percent projected, supported by activity in construction and services. Composite indicators suggest a continued trend in early 2019.

\section{Fiscal developments in FY2018/19H1 are in} line with projections (Figure 4, Tables 2a-d). The authorities' budget execution report for $\mathrm{H} 1$ indicates a lower-than-expected fiscal deficit, reflecting delays in loan disbursements and resulting under execution of capital expenditure. All informal quantitative targets set for end-December 2018 were met.

\section{The National Bank of Rwanda (BNR) eased} the policy stance in its May MPC meeting. Headline inflation has remained below the lower bound of the authorities' inflation target band since September 2018 (0.2 percent $y / y$ in April 2019). Despite some increase in Q1, core inflation also remained below the corridor (1.2 percent). The Monetary Policy Committee (MPC) reduced its policy rate from 5.5 to 5.0 percent at its May 6 meeting to stimulate demand further and bring headline inflation back up within the corridor. Financial sector indicators suggest the banking system is healthy and financial stability risks are low (Figure 5, Tables 3 and 5).

\section{The current account deficit was roughly unchanged in 2018 (Figure 6, Table 4). The} current account deficit was 7.9 percent of GDP in 2018, compared to 7.8 percent in $2017 .{ }^{1}$ This lower-than-expected deficit primarily related to delays in airport construction and more domestic production of construction materials. Import growth did pick up, however, reflecting higher fuel prices, other large construction projects and growth. The Rwandan franc depreciated by 4 percent against the US\$ in 2018.

\section{The latest household survey indicates a} slowing pace of poverty reduction. The 2016-17 Household Living Conditions Survey, announced in December, found that poverty had been reduced to 38.2 percent, a reduction of 0.9 percentage points. The
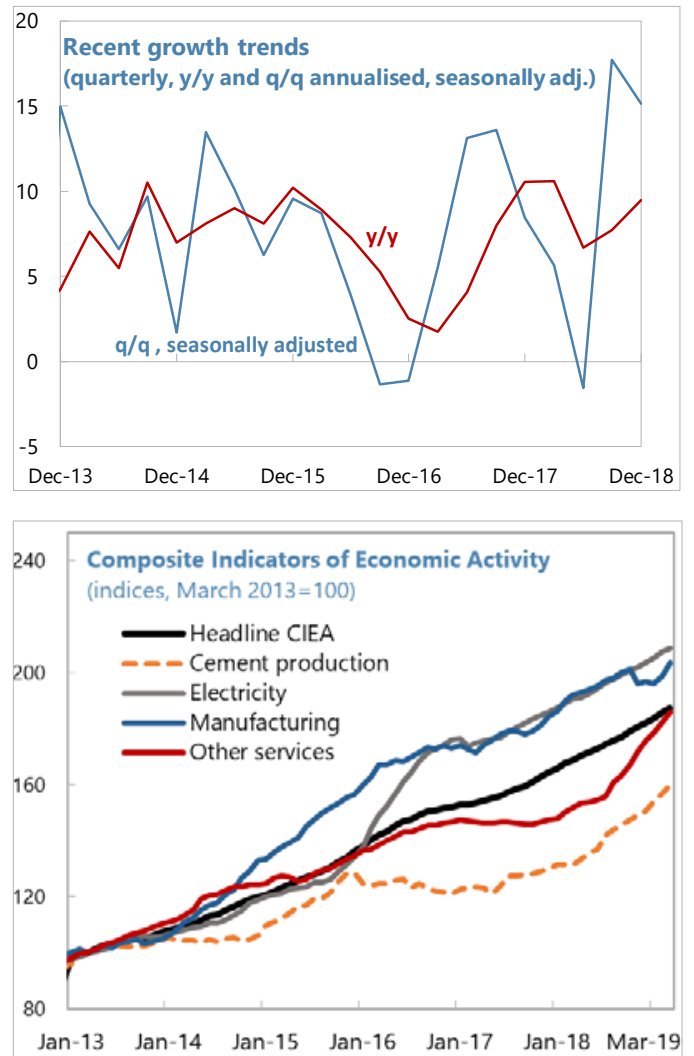
National Institute of Statistics (NISR) attributed the slow pace of decline in poverty to the drought of 2016-17 reflecting the impact of higher food prices on real consumption. The survey also showed that population growth had slowed.

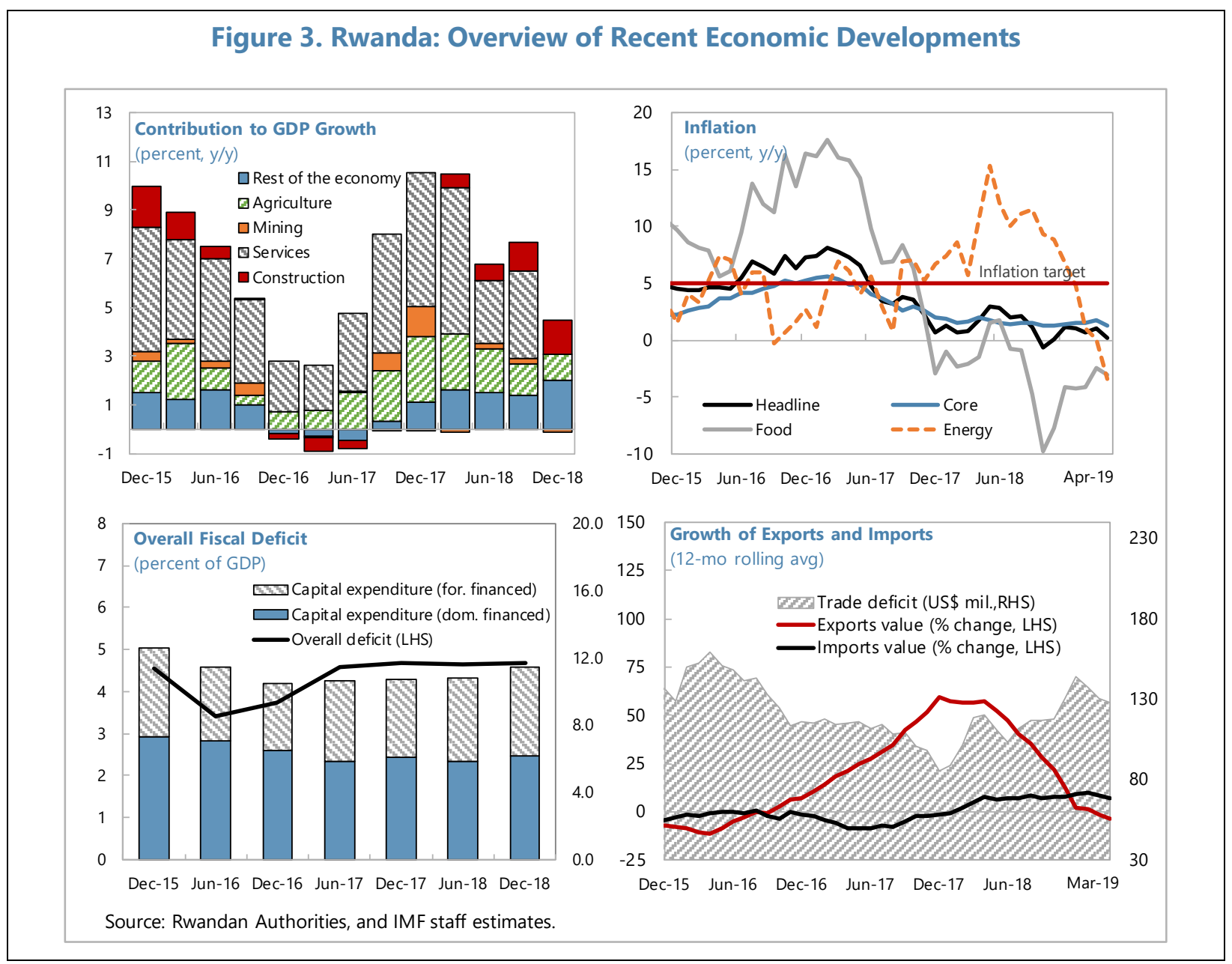

9. Rwanda's growth outlook remains positive (Tables 1-4). Projected growth for 2019 remains unchanged, with several positive factors offset by the base effect of growth in 2018 and uneven rains in Q1. Projections over the next five years have been revised up, to around 8.0 percent, based on first round effects of higher public investment spending agreed under the macroeconomic framework. This does not account for the potential impact on total factor productivity of recent private investment and strategic public investments, which could bring growth closer to the ambitious growth rates imbedded in the NST (Box 2). Inflation is expected to rise in the second half of 2019 and remain thereafter within the target band. The current account deficit is expected to increase in 2019-20, due to airport construction, and decline thereafter. 


\begin{tabular}{|c|c|c|c|c|c|c|c|c|}
\hline \multicolumn{9}{|c|}{ Rwanda: Macroeconomic Framework } \\
\hline & 2016 & 2017 & 2018 & 2019 & 2020 & 2021 & 2022 & 2023 \\
\hline & \multicolumn{2}{|c|}{ Act. } & Prelim. & \multicolumn{5}{|c|}{ Proj. } \\
\hline Real GDP growth (percent) & 6.0 & 6.1 & 8.6 & 7.8 & 8.1 & 8.2 & 8.0 & 7.5 \\
\hline CPI inflation, average (percent) & 5.7 & 4.8 & 1.4 & 3.5 & 5.0 & 5.0 & 5.0 & 5.0 \\
\hline Current account balance (\% GDP) & -15.9 & -7.8 & -7.9 & -9.6 & -9.4 & -7.9 & -8.1 & -7.4 \\
\hline Overall fiscal balance (comm. basis, \% GDP) & -3.7 & -4.7 & -4.7 & -6.1 & -6.4 & -6.2 & -5.1 & -4.9 \\
\hline Gross international reserves (months of imports) & 4.1 & 4.5 & 4.6 & 4.7 & 4.9 & 4.7 & 4.5 & 4.5 \\
\hline \multicolumn{9}{|l|}{ Memorandum items: } \\
\hline & $2016 / 17$ & $2017 / 18$ & $2018 / 19$ & $2019 / 20$ & $2020 / 21$ & $2021 / 22$ & $2022 / 23$ & \\
\hline & Act. & Prelim. & \multicolumn{5}{|c|}{ Proj. } & \\
\hline Overall deficit (comm. basis incl. grants, \% GDP, FY) & -4.9 & -4.4 & -5.5 & -6.0 & -5.5 & -5.2 & -5.0 & \\
\hline Overall deficit (5-year avg., comm. basis, \% GDP, FY) & -4.5 & -4.9 & -5.2 & -5.3 & -5.4 & -5.4 & -5.2 & \\
\hline
\end{tabular}

10. The outlook is subject to balanced risks (Annex III). Risks to the growth outlook are balanced. Acceleration of several large public and private ongoing investment projects (including peat power plant, tin smelting factory, new energy distribution substations and construction of new Special Economic Zones) and their potential impact on productivity, as well as enhanced regional trade ties, pose upside risks to growth. Potential downside risks include lower than expected ODA, variable weather/climate change, commodity price movements, and regional security issues.

\section{POLICY DISCUSSIONS}

\section{Article IV discussions focused on policies to support achieving NST goals while} maintaining macroeconomic stability. After consulting with the government, development partners and other stakeholders over several months, staff identified four main areas for policy discussion, in addition to reviewing structural reforms discussed during NST development and the SDG costing case study. These four areas also constitute the main pillars of agreement, ad referendum, on policy commitments to support the authorities' request for a new $\mathrm{PCl}$-supported program.

- $\square$ recalibrating fiscal objectives and the medium-term fiscal stance;

- $\square$ bolstering domestic revenues over the medium term;

- $\square$ improving public financial management, notably fiscal risk management and transparency; and

- $\square$ supporting the new monetary policy framework, including through easing the policy stance in the near term and financial sector development. 
Box 2. Growth in Rwanda

Rwanda's growth has been historically strong, with below average variance. Despite several external shocks, Rwanda's growth rate has averaged 7.8 percent since 2000. This is the third highest in SSA and exceeds the average of emerging Asia.

\section{Growth rates underlying the Vision 2050 are} ambitious. Reaching the income levels in Vision 2050 would require average real GDP growth rates of greater than 9 percent. This implies higher per capita income increases than observed for most emerging Asian countries.

A simple growth accounting exercise suggests that maintaining historical growth rates is feasible. Over 2000-14, annual labor force growth (3 percent) contributed $1.8 \mathrm{ppt}$ to GDP growth, annual investment growth (13 percent) contributed $3.2 \mathrm{ppt}$, and total factor productivity (TFP) contributed $2.7 \mathrm{ppt}$. TFP has declined recently as repatriation of highly-educated diaspora and ODA levels have waned. Population growth is also slowing. Maintaining high public investment spending can partly compensate for these trends. Strategic public investments-a new cargo-friendly airport, education, leveraging IT--can also enhance TFP, bringing growth rates closer to Vision 2050 ambitions.
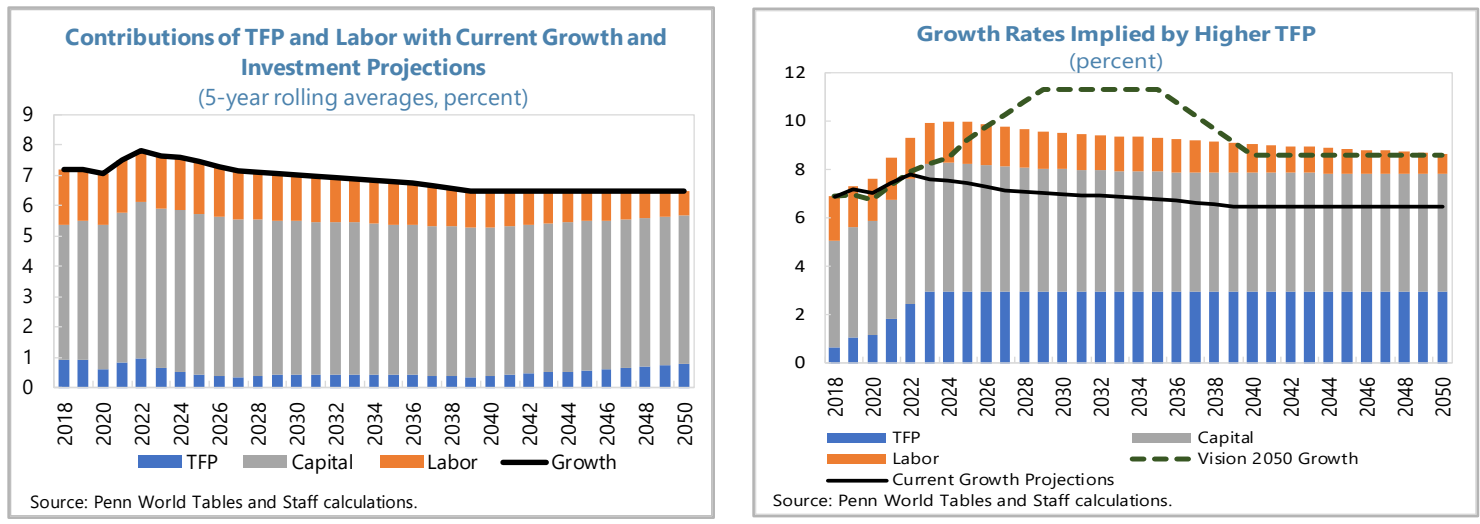

Over the longer term, maintaining high growth will depend on NST policies to boost TFP to historical levels. A recent joint study by the World Bank and Government of Rwanda concluded that maintaining high growth over the long run will depend on progress in six priority areas: (i) significantly higher investments in human capital; (ii) leveraging regional integration for export growth;

(iii) management of urbanization and scarce land resources; (iv) enabling the emergence of competitive domestic private enterprises; (v) a larger contribution of agriculture; and (vi) continuing to strengthen public institutions (which already outpace peer countries). These priorities are imbedded in the NST. 


\section{A. Fiscal Policy and Debt Sustainability: Advancing NST Implementation}

\section{Recalibrating Fiscal Objectives}

\section{The authorities agreed with staff's proposal for a new fiscal framework intended to} support NST implementation while maintaining debt sustainability. The framework under the expired PSI-supported program and Rwanda's medium-term expenditure framework targeted a 3 percent medium-term fiscal deficit, guided by the EAC monetary union (EAMU) convergence criterion. However, this implied a contractionary fiscal stance and unduly constrained public investment spending to implement the NST. Using the EAMU debt convergence criterion as the fiscal anchor (ceiling of NPV of debt-to-GDP of 50 percent), staff proposed to the authorities a new annual operational rule that provides more space (Box 3).

\section{The authorities agreed with staff's proposal for the new}

framework. The proposed new agreed macro framework (Tables 2a-d) assumes a fiscal stance that remains within the 5 -year rolling average ceiling

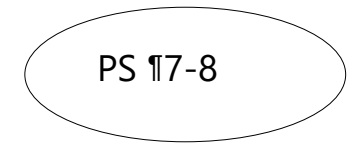
of 5.5 percent of GDP from FY19/20 onward. Compared to the fiscal framework under the nowexpired PSI-supported program, this enables additional spending of some 1.7 percentage points of GDP during FY19/20. The additional public spending will be directed toward NST priorities, mainly education, health, and infrastructure, financed mainly by external borrowing on concessional terms as well as by modest additional domestic revenue. The authorities would have preferred setting the debt-stabilizing deficit ceiling at 6.0 percent, citing the need for frontloaded spending for the NST. Staff encouraged a more cautious approach at the outset, given past accrual of debt, and suggested that the operational rule for the deficit could be revisited pending results of the current Fiscal Transparency Evaluation and subsequent fiscal risk analysis.

\section{For the FY19/20 budget under consideration, an overall fiscal deficit of} 6.0 percent was agreed (Tables $2 a-d)$. The 6.0 percent deficit in FY19/20 partly compensates for a sharp decline in budget grants compared to the previous year ( 0.7 percent of GDP) due to culmination of the allocation by one large donor. In addition, tax and non-tax revenues are projected to decline by 0.7 percent of GDP, mostly due to drop in inflows to finance UN peacekeeping operations. ${ }^{2}$ A marginal decline in tax revenues reflects

\begin{tabular}{|c|c|c|}
\hline \multicolumn{3}{|c|}{ Comparison of FY18/19 and FY19/20 budgets } \\
\hline & $2018 / 19$ & $2019 / 20$ \\
\hline (in percent of GDP) & Proj. & Proj. \\
\hline Revenue and grants & 23.9 & 22.5 \\
\hline Total revenue & 19.0 & 18.3 \\
\hline Tax revenue & 16.1 & 16.0 \\
\hline Nontax revenue & 2.8 & 2.3 \\
\hline Of which: PKO & 1.9 & 1.4 \\
\hline Grants & 4.9 & 4.2 \\
\hline Total expenditure and net lending & 29.3 & 28.5 \\
\hline Current expenditure & 15.0 & 14.3 \\
\hline of which: PKO & 1.8 & 1.7 \\
\hline Capital expenditure & 12.0 & 11.7 \\
\hline Net lending & 2.4 & 2.4 \\
\hline Overall balance (incl. grants, comm. basis) & -5.5 & -6.0 \\
\hline \multicolumn{3}{|l|}{ Memorandum items: } \\
\hline Net PKO & 0.1 & -0.3 \\
\hline GDP (Billions of RwF), FY basis & 8,694 & 9,821 \\
\hline
\end{tabular}
regional trade shifts (lower interregional tariffs) and more domestic production of previously-

\footnotetext{
2 Net outlays for UN peacekeeping operations increase by 0.3 ppt of GDP in FY19/20. UN peacekeeping operations and their subsequent reimbursement is deficit-neutral over a period of years, but not in any given year.
} 
imported goods. To address these shortfalls, current and capital spending have been reduced, by 0.7 and 0.3 ppts, respectively.

\section{A new joint DSA from Fund and Bank staffs suggests that Rwanda's risk of debt} distress remains low (Attachment 1). Rwanda's nominal debt levels (including guarantees) have risen rapidly in recent years with the aim of financing strategic growth-enhancing public investment. However, the authorities relied on mostly concessional financing, on the backdrop of strong growth in GDP, exports and domestic revenues. Compared to the most recent DSA (Ninth review of the PSIsupported program), the current DSA reflects higher GDP growth and public investment spending over medium-term (5 years), and an accelerated decline in growth over the longer term (to 6.5 percent after 20 years) reflecting declining contributions of labor and productivity. Under the baseline scenario of the DSA, the PV of external debt to GDP would rise gradually from 29 percent currently to under 35 percent over the next ten years, providing ample space relative to the countryspecific and the LIC DSF stock risk thresholds. Maturation of the 2013 Eurobond in 2023 causes a one-year temporary breach in debt service thresholds, which is exempted in line with DSF policy, and rollover risks are low. Otherwise, all stress tests remain below risk thresholds, as does a customized stress test hypothesizing the impact if the government were to take full financial responsibility for construction of the new airport, on non-concessional terms.

\section{Bolstering Domestic Revenues}

16. Rwanda made notable progress in boosting domestic revenues in the past decade, but momentum in the past 2-3 years has slowed. Tax revenues increased by 5 ppts of GDP in the decade leading up to FY15/16, rising to around 16 percent of GDP and outpacing peer country averages. Given Rwanda's aspirations, continuing the momentum will be important. Analysis suggests that there are additional areas for improvement (Box 4). However, the potential is limited, given Rwanda's income level and large informal sector: staff analysis indicates further potential could be $2-3$ ppts of GDP. ${ }^{3}$

\section{The authorities and staff agreed on measures aimed to boost tax} revenues annually by 0.2 ppt of GDP beginning in FY20/21. To improve corporate income tax (CIT) productivity, the authorities will draw from TA

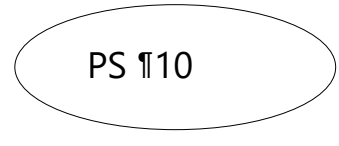
recommendations, including from the IMF, and are committed to refine their annual tax expenditure analysis and seek areas to streamline exemptions (Reform Target Table, RT). They are also seeking TA recommendations on how to strengthen tax policy capacity in the Ministry of Economic Planning and Finance (MINECOFIN) and develop a medium-term revenue strategy, among others. To improve VAT efficiency further, the Rwanda Revenue Authority (RRA) will detail options under consideration for improving VAT functioning, e.g., incentive schemes for consumers. It will also automate a riskbased verification process for handling VAT refunds (RT). An updated Tax Administration Diagnostic Assessment (TADAT) was requested by the authorities and conducted in April 2019; its recommendations will provide a framework for additional reforms. The resulting tax policy and administrative measures should allow for a more ambitious revenue effort over the medium-term.

${ }^{3}$ SSA Regional Economic Outlook, Chapter 2, April 2018. 
Box 3. Proposed Changes in Rwanda's Fiscal Framework

Rwanda's previous medium-term fiscal framework was guided by EAMU fiscal convergence criteria. The EAC monetary union protocol, signed in November 2013, requires member countries to meet primary convergence criteria by 2021, to be maintained for three consecutive years when the single currency should be launched in 2024. Two of the primary criteria are keeping: (i) the fiscal deficit including grants at or below three percent of GDP; and (ii) gross public debt in present value terms at or below 50 percent of GDP. This creates two problems. First, in Rwanda's case where the PV of debt is well below 50 percent and external financing is highly concessional, a 3 percent deficit is overly constraining. Second, the scope of the EAC deficit criterion remains undefined regarding inclusion of investment spending, which is high in Rwanda relatively to other EAC countries. The authorities have effectively considered "maintaining a low risk of debt distress" as a guiding principle, but this is difficult to operationalize in the annual budget process.

\begin{tabular}{|lccc|}
\hline \multicolumn{3}{|c|}{ Rwanda: Debt stabilizing overall fiscal balance } \\
(percent)
\end{tabular}

Staff's proposed fiscal framework creates a more explicit link between setting the annual deficit and containing debt risks, using the EAMU debt criterion. It also emphasizes simplicity, flexibility, and provision of good operational guidance. ${ }^{1}$ The premise was to seek a deficit level that would stabilize the PV of debt at or below 50 percent of GDP. Currently, the deficit covers the budgetary central government which is the largest debt-creating entity, while other types of public debt and guarantees are monitored separately and included in the DSA.

Staff calculations indicate that an annual overall fiscal deficit of 6.7 percent of GDP, all else equal, would cause the PV of debt to converge gradually to $\mathbf{5 0}$ percent of GDP. This is arrived at using "debt maintaining overall balance calculation" and is based on (i) about 10 percentage points difference between nominal and PV of public debt; (ii) the average real growth projections of 7.5 percent $y / y$ over the next 15 years; and (iii) GDP deflator growing at 5 percent $y / y$.

Varying growth and ODA assumptions changes the debt-stabilizing fiscal balance. To check the robustness of results, staff considered two shocks to the baseline: lower growth and lower ODA financing. If average nominal GDP growth was assumed to be lower by one standard deviation (based on 2009-18), the debt-stabilizing deficit would tighten to 5.5 percent of GDP. Next, assuming a higher share of nonconcessional borrowing, which brings the PV and gross values of debt closer, the debt-stabilizing deficit would tighten to 6.2 percent of GDP.

In this context, staff recommended a 5.5 percent deficit ceiling, which provides a broadly neutral fiscal stance over time, but also a buffer for shocks and debt creation outside the budget. $A$ 5.5 percent of GDP deficit ceiling-assuming nominal growth of 12.5 percent and no off-budget debt creation-would stabilize the PV of debt to GDP below 40 percent of GDP. Staff recommended that the ceiling be applied as a five-year rolling average, centered on the current year. This provides, in any given year, space for lumpy investment spending, uncertain donor flows, shocks, and materialization of potential fiscal risks not included in the baseline. This ceiling would need to be recalibrated intermittently in future years. Staff recognized that such an operational rule would be used for developing the macro framework under the program, but could not be inscribed in domestic law, since the EAC deficit criterion-once agreed--would take precedence. This also obviated consideration of accompanying "escape clauses."

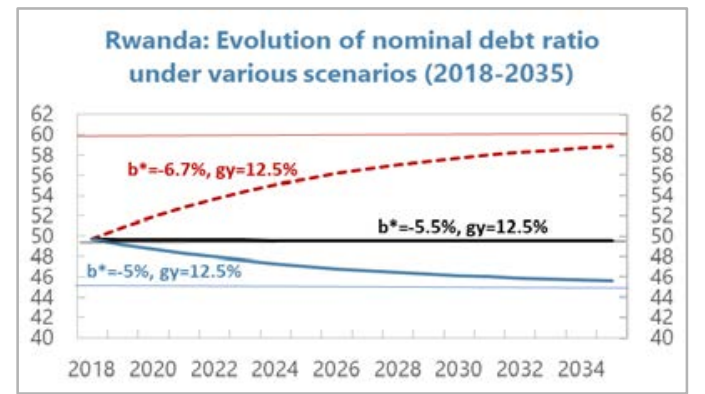

"The proposal draws from FAD "How to" notes on selecting and calibrating fiscal rules, published in 2018. 


\section{Box 4. Domestic Revenue Mobilization}

Rwanda's persistent efforts in mobilizing tax revenues have paid off. A major policy objective has been mobilizing domestic revenues to reduce dependency on ODA. Relative to initial per capita income levels, Rwanda's tax revenue gains were noteworthy. By 2017, tax revenues reached slightly below lower middle-income country (LMIC) levels. Main contributors to this impressive performance included appropriate sequencing of revenue mobilization reforms in the post-conflict environment. ${ }^{1}$

- $\square$ The initial focus, in the latter half of the 1990 s, was on fast gains such as high-yielding excise taxes, and customs duties at the border since these are less prone to evasion. This provided the basis for the adoption of VAT in 2001, replacing the erstwhile turnover tax. The RRA was established in 1997 as the single revenue collection agency. It focused on key compliance areas (registration, filing and payment), streamlined basic procedures, and established a Large Taxpayer Office.

- During the first half of 2000 s, the focus was on broadening tax collection beyond large taxpayers, and in the past decade, the focus has been on modernizing fiscal administration through medium term revenue and expenditure strategies.

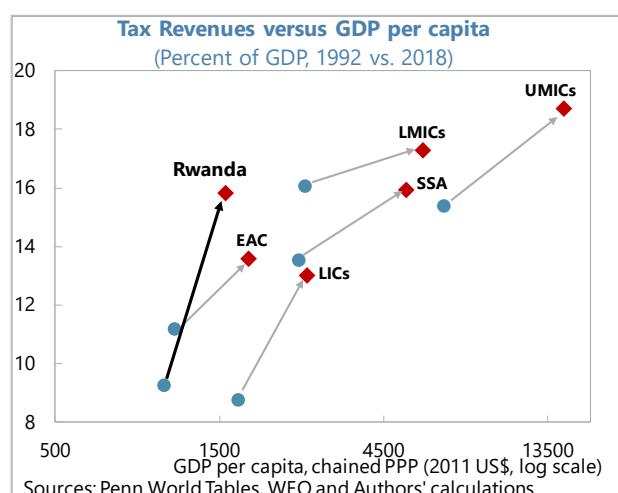

Sources: Penn World Tables, WEO and Authors' calculations.

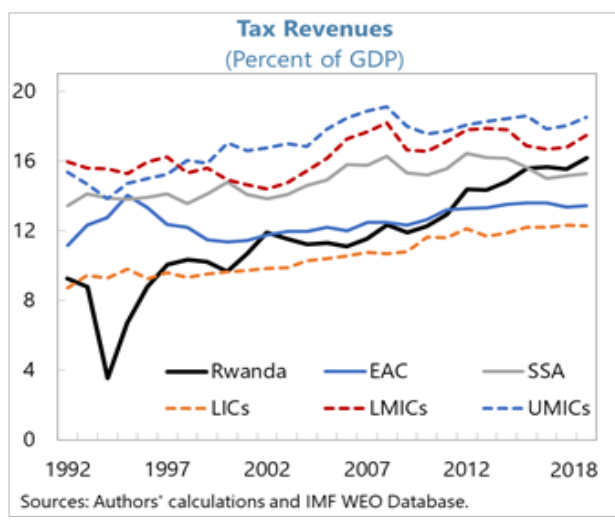

Good performance of direct taxes and continuous improvement of revenue administration are two components of Rwanda's tax mobilization success story. Rwanda's direct tax collection nearly trebled over the postconflict period, surpassing the level for upper-middle income countries (UMICs) by 2017. This largely due to the personal income tax (PIT), which characterized by progressive nominal income rate brackets unchanged for 15 years, with coverage gradually expanding as incomes rise. Equally more important have been RRA's measures to improve compliance, such as income tax withholding. A 2015 TADAT and implementation of follow up TA recommendations have brought about further administrative gains including: cleaning up the tax registration database; reconciling taxpayer ledgers; strengthening risk management; and introducing e-payments.

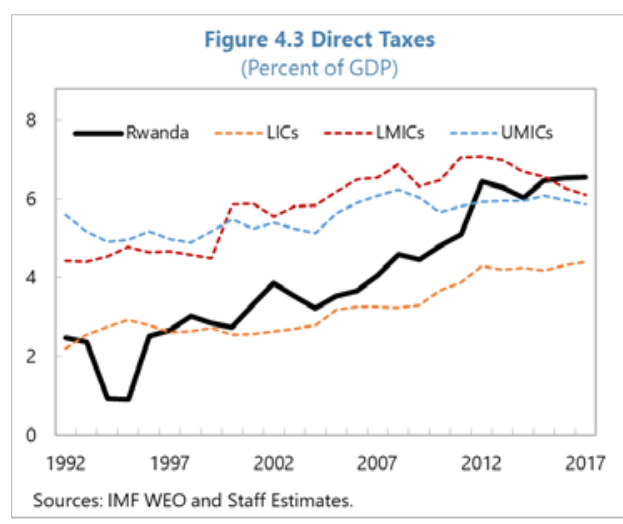

However, CIT productivity and VAT efficiency lag peer countries. Productivity for CIT is lower than peer countries, reflecting system-wide incentives to encourage private investment. Taxes on international trade are lower than comparators, except the EAC, reflecting intra-EAC trade and a lower common external tariff for the EAC customs union. Taxes on goods and services are in line with LMICs, but VAT efficiency lags peers due to compliance problems. 


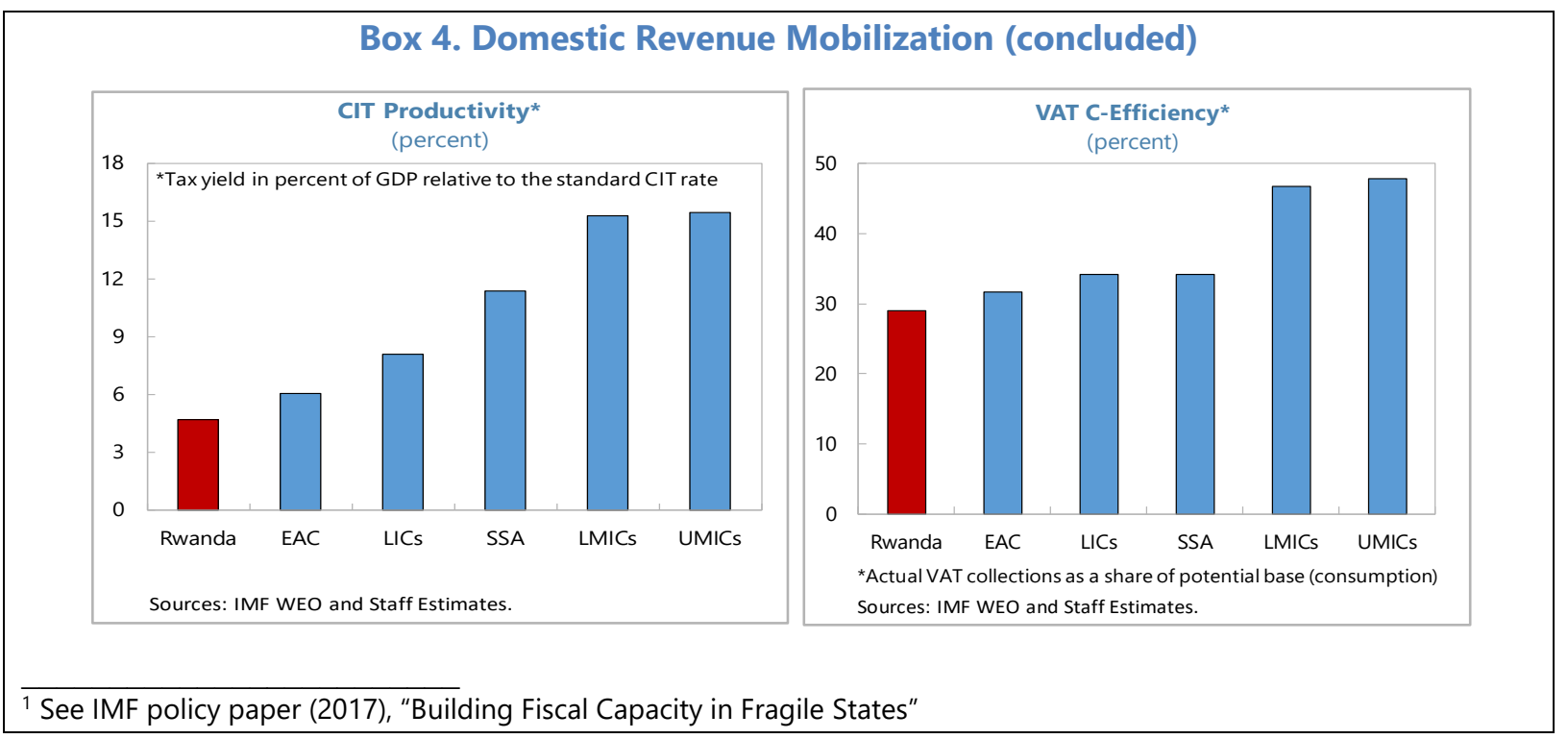

Improving Public Financial Management (PFM), Notably Fiscal Risk Management, and Transparency

18. Rwanda's public financial management is generally considered very strong, but there are areas for improvement. There is a robust legal framework for fiscal management, complemented by a home-grown MINECOFIN PFM reform program. An Integrated Management Information System (IFMIS) tracks spending, and supports planning, budgeting, reporting, and auditing functions. With the help of IMF TA, the government is also implementing medium-term and performance-based budgeting and accrual accounting under International Public Sector Accounting Standards (IPSAS). However, there are areas for improvement, notably in undertaking more fiscal risk analysis and management and publishing more fiscal reports. The authorities are also committed to improve PFM practices in the Rwandan Social Security Board (RSSB), which-although fully government-owned-operates autonomously (RT).

19. In the area of fiscal transparency, the authorities agreed to move program monitoring and budget execution reporting to the GFSM 2014 presentation. Rwanda has been moving annual budget reporting to the GFS

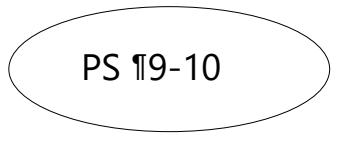
2014 standard, which allows better reconciliation fiscal flows and balances. Under the proposed program, the authorities have also committed to produce quarterly reports in GFS 2014 (RT). They also plan to expand fiscal coverage, from the current budgetary central government, to the broader central government and, eventually, the general government (RT). While Rwanda generally produces good fiscal reports, more could be published and there are long lags in publishing audited consolidated financial statements. A Fiscal Transparency Evaluation (FTE) undertaken in May 2019 will provide specific recommendations, including on improving fiscal reporting. The authorities plan to follow up these recommendations with an action plan.

20. The proposed program also contains commitments by the authorities to improve fiscal risk management systematically. While Rwanda has good reporting on debt obligations and 
guarantees, staff have been encouraging systematic assesssment of potential contingent liabilities, e.g. from PPPs. Following the current FTE and its recommendations, the authorities have commited to conduct a comprehensive fiscal risk analysis, which will benefit from TA from AFRITAC East (RT). Additional reform measures can be considered for the program following these exercises.

21. To ensure the most productive use of resources, the authorities also want to implement better PFM practices at the RSSB, the largest single financial entity in the country. The RSSB operates six schemes, covering both pensions and health insurance, and manages about RwF900 billion (10 percent of GDP) in assets. The proposed program contains structural reform targets that would automate RSSB operations, with the intent of reducing losses, improving efficiency, and enhancing transparency via regular financing management reporting. RSSB is also seeking outside TA to determine options for improving its current asset allocation. RSSB is also the largest single depositor in the domestic commercial banking system.

\section{B. Monetary Policy: Strengthening the Operational Framework and Developing the Financial Sector}

\section{New Monetary Policy Framework and Easing the Policy Stance}

\section{The BNR transitioned to a new monetary policy framework on January $\mathbf{1}$ and staff} proposed a new program monitoring framework. After a transition to ensure that initial conditions were adequate, the BNR announced a move from a framework targeting monetary aggregates to an interest rate-based framework (Box 5). The new framework is being combined with new infrastructure and measures to more actively manage liquidity (including through a daily committee), enhance communication, and deepen money markets and financial markets more generally while maintaining financial stability.

23. In light of inflation below the authorities' target range, staff encouraged easing of the monetary stance during its March mission. The authorities were ambivalent, since they felt an overly tight fiscal stance had been a drag on inflation in the past and because their quarterly forecast showed a pick-up in inflation in the second half of 2019. Based on its own quarterly projection model, staff agreed that inflation should pick up in the second half of the year, based on receding base effects of the positive food supply shock in 2018 and rising fuel prices. However, staff expressed concern in the meantime about low inflation expectations becoming entrenched and the drag of very high real interest rates on private sector activity.

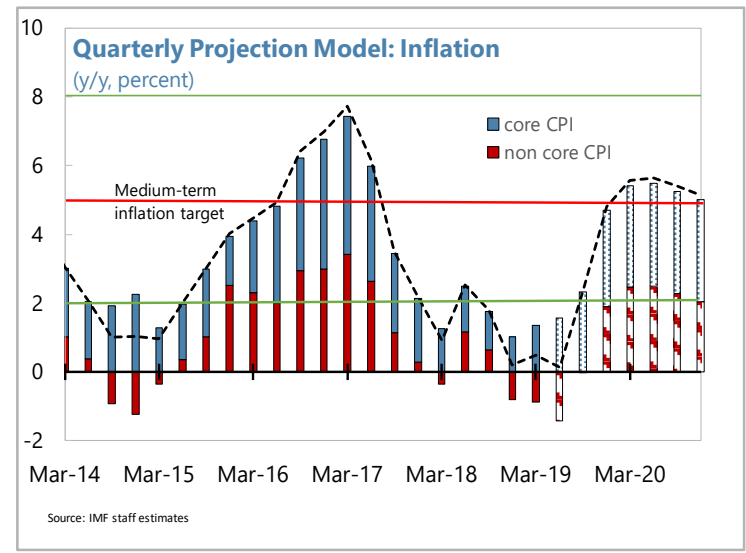


Box 5. BNR's New Monetary Policy Framework

The BNR announced its formal transition to an interest rate-based operational framework, as of

January 1, 2019. The transition was in response to a changing financial landscape, marked by use of innovative financial services and financial deepening, with the credit-to-GDP ratio increasing from 12 percent in 2010 to around 20 percent in 2017. These developments led to increased unpredictability of money demand, weakening the link between reserve money and inflation.

The transition to the new framework has been gradual. A policy rate and an interest rate corridor were introduced in 2008 and 2012, respectively. Since 2016, the BNR started to reduce excess reserves in the banking system, ensuring that the interbank and repo rates have begun to align with the policy rate. In addition, the BNR has introduced reforms to stimulate the interbank market and develop its forecasting capacity, with help from IMF TA. That analysis has been augmented with price and market expectations surveys. However, transmission of policy rate changes to lending rates remains weak.

The new framework is composed of a medium-
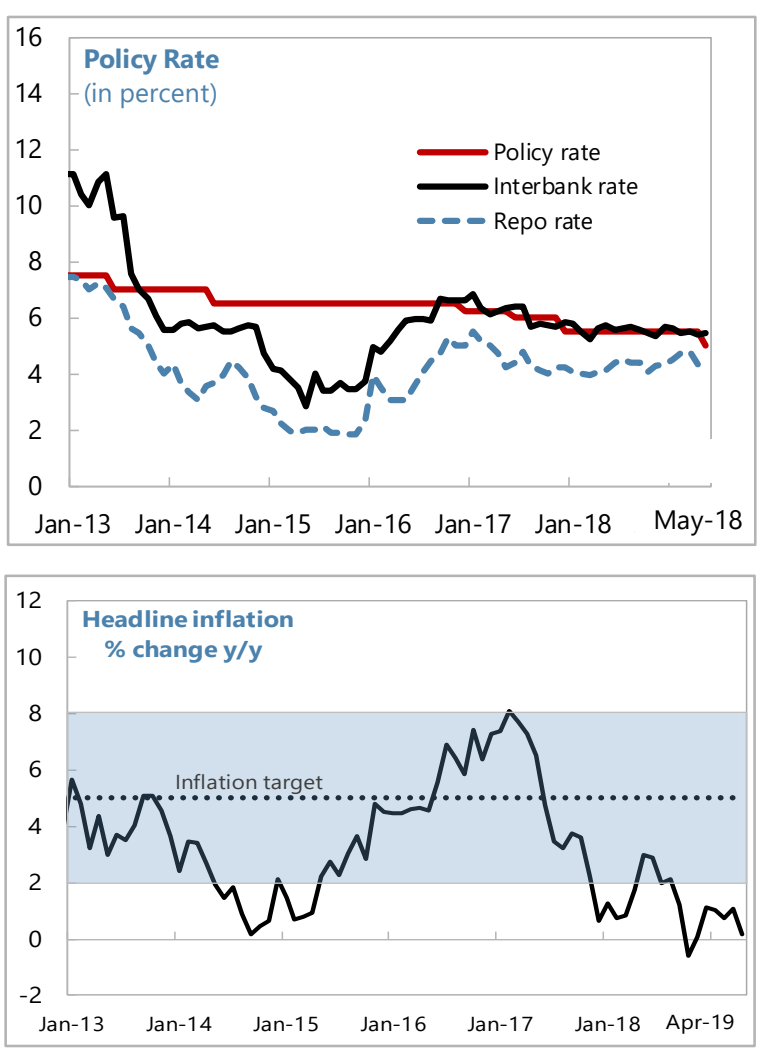
term headline inflation target of 5 percent, with an inflation target band of \pm 3 percentage points. The BNR chose headline inflation as the target for the purposes of simple communication. In practice, since headline inflation is largely driven by food and fuel price changes, the BNR will also monitor core inflation movements. The interest corridor around the policy rate was set with the standing lending rate of $100 \mathrm{bps}$ above and the standing deposit rate 200 bps below. Since 2013, headline inflation has breached the floor of the inflation target band several times. Movements below the floor have largely been related to positive supply/external shocks, reducing food and fuel prices.

24. The Monetary Policy Committee (MPC) reduced the policy rate by $\mathbf{5 0}$ basis points in its May 6 meeting. The MPC observed that domestic demand continued to grow in the first quarter of 2019, supported by growing credit to the private sector. However, given the still-low inflation environment, it chose to reduce the policy rate to sustain growing domestic demand. While the reduction in the policy rate was modest, staff concur that it makes sense to assess how a somewhat easier fiscal policy stance affects domestic demand and inflation, particularly in the context of an already-expected acceleration of inflation in the second half of the year. The MPC also noted in Q1 a slight decline in average lending rates (29 basis points) following a larger decline in average deposit rates (69 basis points). The MPC explained that aggregate demand in 2019 should continue to improve, supported by a more accommodative monetary policy and increased fiscal stimulus. 
25. The authorities and staff also agreed on structural reform targets to support implementation of the new policy framework. An important undertaking is the commitment for developing a "true" repo market, including plans for the maturity structure of open market operation instruments and ensuring consistency of master repurchase agreement with the BNR Directive and Code of Conduct (RT). To supplement their growing forecasting capacity, the authorities plan to expand industrial and market expectation surveys (RT). Similarly, the BNR is beefing up its communication strategy to help strengthen monetary policy transmission. Near term measures include targeted outreach following MPC meetings and publishing, four quarters ahead, macro projections underlying MPC decisions (RT).

\section{The authorities also reiterated their commitment to exchange} rate flexibility. Rwanda's exchange rate regime is currently determined by the AREAER process to be a "crawl-like" arrangement. The BNR feels it should

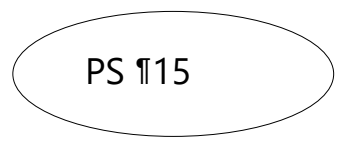
be considered as a "floating" regime, but it would be difficult to meet the requirements for a truly floating exchange rate regime in a small country like Rwanda, which has large donor inflows, the central bank as the main source of foreign exchange, and very limited short-term capital account flows. An updated external assessment (Annex IV) suggests that Rwanda's external position - after sharp improvement in recent years, with notable exchange rate adjustment - is broadly consistent with fundamentals and desirable policy settings. International reserves are currently well within the optimal range and forecast to remain there. Eventually, deeper foreign exchange markets should lead to higher foreign exchange rate variability and better price discovery, including in forward markets.

\section{Financial Sector Development and Stability}

\section{The authorities have a broad-ranging reform plan to deepen}

financial markets. These are intended to bolster domestic savings, encourage the private sector as an engine for growth, and support the NST (Box 6). For the proposed program, structural reform targets include introducing a platform for issuing government securities using mobile phones and conducting a study of consumer payment behavior to determine how to transition to a cashless economy (RT).

28. Financial indicators point to a broadly healthy system (Table 5). The banking sector remains liquid, profitable, and well-capitalized well within minimum requirements. NPL ratios declined, reflecting mainly write-offs, while provisions increased significantly mainly due to IFRS 9 implementation. Staff welcomes the central bank's continued efforts to comply with international standards as well their commitment to ensure such compliance does not undermine financial sector intermediation and development, through reviewing the legal and regulatory framework. The authorities have requested a new financial system stability review, which, in conjunction with planned AFRITAC activities, could support the implementation of an effective development finance framework and more active capital markets, while ensuring the continued compliance with IFRS provisioning and adoption of Basel II and III standards. The central bank has stipulated an action 
plan to strengthen oversight of non-traditional financial service providers in the advent of fintech while encouraging innovation, and signed MOUs with other domestic regulators (e.g. of telecoms).

\section{Box 6. Rwanda's Financial Sector Development Strategy}

Rwanda's financial sector development strategy aims to bolster domestic savings, increase access to financial services, move to a cashless economy, develop a domestic capital market, and serve as a hub for specialized financial services activities.

- $\square$ A government-sponsored long-term saving scheme (LTSS) aims to provide pension benefits to half the population not covered by existing schemes. It is based on voluntary contributions into a savings account, with the pension value based on collective investment returns. Depending upon income level, a limited government matching contribution and life insurance are available. About 30,000 people have signed up since its launch in December 2018.

- $\square$ Financial access is expanding, both through government programs and home-grown fintech. Mobile and other e-commerce has helped, but access for the agricultural sector (where formal financing is less than 2 percent and more than 75 percent of the labor force earns its living directly or indirectly) remains challenging. The authorities have implemented a risk-sharing scheme to increase bank financing and insurance, and electronic platforms are being developed to help farmers buy inputs and repay loans.

- $\square$ The authorities are promoting a cashless economy to improve efficiency and develop a culture of tax compliance. Electronic payments are growing quickly, due to high mobile phone penetration (almost 90 percent) and greater interoperability of retail payment systems (ATMs, points of sale, and mobile channels). As a result, the value of e-money has increased from effectively zero in 2011 to 34 percent of GDP in 2018 (BNR 2019 Monetary Policy and Financial Stability Statement). Digital financial services (lending and savings) are also growing very rapidly.

- Capital market development is being guided by a ten-year plan to help Rwandan businesses, which tend to be small and informal, to improve financial records and strengthen corporate governance. The authorities are promoting: "investment clinics" to nurture small entrepreneurs; more intra-EAC capital flows to boost the institutional investor base; and collective investment schemes and access to government securities for retail investors.

- $\square$ The authorities hope to develop Rwanda as a regional center for a commodity market that can complement the activities of already-established financial centers, notably Nairobi. A commodity market can to help set spot and future prices to improve price transparency and trading intra-regionally. The spot market in Rwanda is already well advanced.

\section{Structural Policies: Encouraging the Private Sector}

\section{The NST lays out a wealth of public interventions to support} accelerated growth and job creation. Rwanda has made good progress in increasing employment and productivity in services and manufacturing.

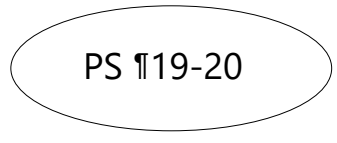
However, agriculture continues to account for 30 percent of economic activity and provides livelihoods, directly or indirectly, for the majority of its citizens. The NST targets economic transformation through the creation of new employment in higher value-added sectors through public interventions designed to accelerate growth and create jobs (Box 6). 
Box 7. Selected Additional Public Interventions to Bolster Growth and Employment

Under the NST economic transformation pillar, wide-ranging government interventions are designed to increase growth, employment and private sector investment. Some additional examples:

- $\square$ Along with development of the Kigali Innovation City (KIC), the government has established: an innovation fund; a national digital literacy program; and training centers focused on science, technology and innovation. For example, Carnegie Mellon University Africa (CMU-Africa) was established in 2011 to produce creative and technically capable engineers. The African Institute for Mathematical Sciences opened in 2016, offering postgraduate training in math and science, and promotes research and innovation for scientists across Africa.

- $\square$ The government created the National Industrial Research \& Development Agency (NIRDA) to promote R\&D through helping adapt specific technologies to enhance productivity; research and development to develop new niche industries; and tech information and training for firms.

- $\square$ Special Economic Zones (SEZs) to provide all supporting services (water, electricity, internet, storage, etc) for attracting investors in manufacturing. The first SEZ, the Kigali Special Economic Zone (KSEZ), has 94 plots that are fully booked, with 65 companies in operation. A second phase with 66 additional plots is more than 90 percent booked. Several new investors are manufacturing construction materials, with small investors coming from elsewhere in the EAC region. Based on the success so far, additional SEZs are under development throughout Rwanda, including with private sector development.

- $\square$ The Rwandan Development Board (RDB) is pro-active in seeking new foreign investment, particularly to value chains in areas deemed as having good potential (agro-processing, construction materials, light manufacturing, meat and dairy, leather, textiles and garments, horticulture, tourism, knowledge-based services, and transport). A few examples promoted by RDB in recent years with investments over US\$10 million: a Kigali "dry port," a top-end tourism hotel; a substantial upgrade of Kigali's main hospital; a new tin smelting plant; and a new tantalum refinery.

\section{Private sector engagement is critical for achieving good NST outcomes given current}

limited fiscal space and ODA trends. The NST is also focused on interventions to enhance private sector competitiveness. The combination of ODA trends, limited potential for DRM and improving spending efficiency, as well as the government's intentions to maintain debt sustainability will make NST financing in the future increasingly challenging. Private sector engagement is a must for achieving the Vision 2050 ambitions. However, Rwanda already scores at or near the top on SSA rankings of competitiveness, the business environment, governance, and public investment and expenditure efficiency. Although private investment has grown rapidly over the past 15 years-from about 5 percent in 2000 to about 12 percent in 2018 - the economy continues to be dominated by the public sector. The question remains how to attract significant private investment in a landlocked country with a relatively small economy and still very high transportation and energy costs. The Continental Free Trade Area (CFTA) and EAC regional ties can help expand the size of the market, but only over the medium-long term.

\section{To help leverage private investment, the authorities are encouraging more "blended} finance" in the context of the G-20 Compact with Africa initiative. To tap into the vast pool of global private savings without taking more liabilities onto the government balance sheet, the government has strongly encouraged development partners to consider offering more and easier to-use ODA tools that leverage private finance, that is, "de-risking instruments" or "blended 
finance". ${ }^{4}$ For their part, the authorities are focused on directing new financing associated with CWA toward affordable housing and export promotion, with renewed support from key development partners, notably the IFC which has significantly increased its activities in the country. They have also introduced de-risking instruments domestically to help private commercial financing to entities, e.g., farmers, whose activities would otherwise be seen as too risky.

32. The authorities are also committed to improving the quality and transparency of national statistics. They have subscribed to e-GDDS and launched a National Summary Data Page in September 2017 and are now

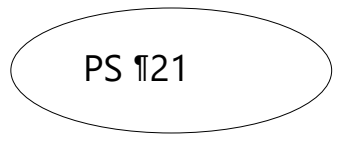
committed to subscribing to SDDS by the end of the program period. The current focus is on enhancing the Monetary and Financial Statistics as well as in publishing quarterly International Investment Position statistics by early 2020.

\section{PROGRAM MODALITIES AND RISKS}

\section{The attached Program Statement (PS) details the authorities' policy commitments} under a 3-year program supported by the Policy Coordination Instrument. Rwanda meets the criteria stipulated for use of the $\mathrm{PCl}$, and current analysis does not indicate present, potential, or prospective balance of payments needs. Proposed program reviews for the first 12 months are set out in PS Table 1a, with quantitative targets for a set of key macroeconomic variables to be monitored on a semi-annual basis: budgetary central government fiscal deficit, net foreign assets of the central bank, domestic payment arrears, and a monetary policy consultation clause (see paragraph 35). There is also continuous target on the non-accumulation of external debt payment arrears. The program will also monitor domestic revenues, priority spending, and external debt of nonfinancial public enterprises. In addition. standard continuous targets on trade and exchange rate restrictions, bilateral payments arrangements and multiple currency practices shall apply throughout the term of the PCI (PS Table 1b). Structural reform targets over the next 18 months in the areas of public financial management, domestic revenue mobilization, monetary policy, financial sector, are proposed in PS Table 2. Statistical data are adequate for surveillance and program monitoring.

34. The authorities agreed with staff's proposal to move to a monetary policy consultation clause (MPCC) for monitoring the program. Rwanda's current monetary conditions align with those for which the MPCC is recommended. ${ }^{5}$ That is, central bank independence, an understanding of the determinants of inflation, expectation surveys, and an increasing focus on an inflation objective. The country would not be prepared for inflation targeting, given weak policy transmission and shallow financial markets.

\footnotetext{
${ }^{4}$ Blended finance refers to the use of development finance to lower the risk-return ratio of projects in order to make them more attractive to private investors. Existing "de-risking" instruments offered by development partners have been catalogued in a CWA "toolbox": https://www.compactwithafrica.org/content/dam/Compact\%20with\%20Africa/inventoryofinstruments/cwa inventor y 2017.pdf

5 The MPCC proposal drew from the 2014 IMF Policy Paper and the 2015 IMF Staff Report on "Evolving Monetary Policy Frameworks."
} 


\section{Staff specifically recommended evaluating a moving inflation average against inner} and outer MPCC bands. The inner band-—with breaches triggering consultation with IMF staffconforms to the authorities' inflation corridor. The outer band — with breaches triggering consultation with the Executive Board-is one percentage point on either side of the inner band. Both bands would be evaluated against a 12 -month moving average of $\mathrm{y} / \mathrm{y}$ inflation. As experience accrues with the new framework, the outer band should be narrowed or eliminated and the period for calculating the moving average should be shortened. Currently, the 12-month

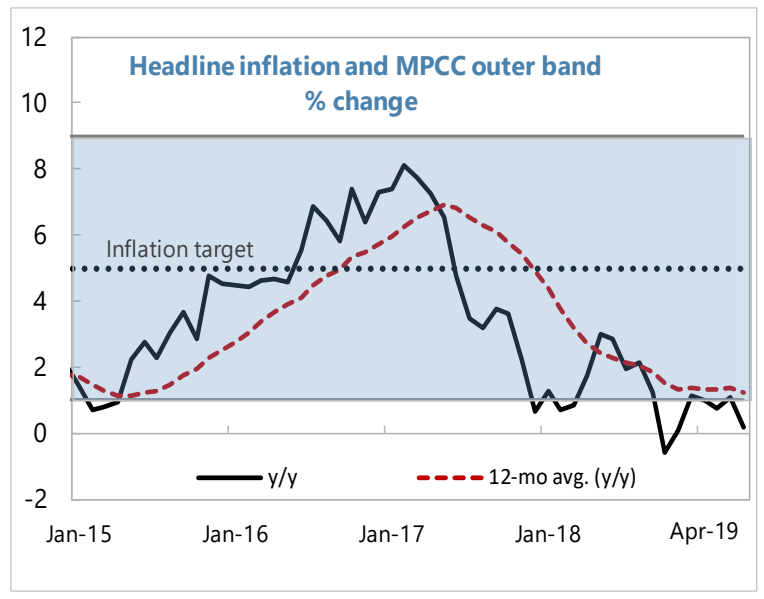
moving average for $y / y$ inflation remains just inside the outer consultation band.

36. Risks to program implementation are low, given Rwanda's strong macroeconomic and program performance track record. The program is fully financed for 12 months with good prospects for the remainder of the program and there are no sovereign arrears to bilateral, multilateral or commercial creditors. A safeguard assessment is not required under the $\mathrm{PCl}$.

\section{STAFF APPRAISAL}

\section{Rwanda has achieved notable success in reaching its development objectives. A} combination of strategic goal-setting, public accountability, and broad ownership of policies has helped the country emerge from fragility as one of the fastest-growing economies in SSA and the world. Moreover, growth has been inclusive, and extensive investment in social safety nets has reduced poverty significantly. At the same time, macroeconomic performance has been characterized by discipline policies, with flexible responses to shocks.

38. The new requested PCI-supported program aims to support NST implementation while maintaining low debt risks. Staff welcomes the agreement to adopt a new fiscal operational rule that will provide a more neutral fiscal stance over the medium term and provide more room for NST priority investments, while maintaining Rwanda's low risk of debt distress. NST implementation will be further reinforced by planned measures for building on domestic revenue gains. In the tax policy area, plans are in place to evaluate and streamline tax exemptions, strengthen tax policy capacity, and develop a medium-term revenue strategy should help. This will be reinforced by reforms to strengthen tax administration further, drawing from an updated TADAT. Staff also welcomes authorities' commitments to identify and mitigate potential fiscal risks, including by improving the efficiency and transparency of RSSB's operations.

39. The authorities' new monetary policy operational framework is an appropriate response to a changing financial landscape. The central bank has made good progress in ensuring that money market rates converge with the policy rate, and nascent progress in 
strengthening transmission to longer-term rates. Staff welcomes the MPC's decision to ease the monetary policy stance to help guide inflation expectations and bring inflation back within its targeted range. Going forward, steadfast implementation of commitments to strengthen communication and further deepen money markets, including by strengthening the repo market, should help strengthen monetary policy transmission and enhance credibility of the new framework.

40. Measures to intensify financial development and capital markets, drawing on ICT, will also help improve financial inclusion, reinforce stability, and support the NST. Implementation of the financial sector development strategy should bolster domestic savings and improve lending conditions. Staff welcomes authorities' reform efforts to bolster long-term savings and upgrade the national payments system to promote a cashless economy, as well as plans to introduce new platforms for broader participation in the government securities market and more interaction across types of financial services providers.

41. Staff supports the NST policies on growth and job creation which will also support SDG achievement. However, financing the plan will be challenging, as there is limited fiscal space and ODA trends are declining. Going forward, Rwanda's ambitions for Vision 2050 and SDG achievement will require new and innovative approaches, and a renewed focus on the quality of education and private sector-led growth. Staff salutes the authorities' efforts to encourage development partners to use ODA more strategically to leverage private financing.

\section{The $\mathrm{PCl}$ provides an appropriate instrument to support the authorities'} macroeconomic policies and commitments. With the external position broadly consistent with fundamentals and desirable policy settings, a gradually more diversified economy, a sound and resilient financial sector and comfortable international reserves, the authorities and staff do not foresee a potential balance of payments need over the forecast horizon. Staff thereby supports the authorities' request for a 3-year $\mathrm{PCl}$-supported program. It is proposed that the next Article IV consultation takes place within 24-months in accordance with Article IV Consultation Cycles Decision No. 14747-10/96. 
Figure 4. Rwanda: Fiscal Developments

Total revenues have remained broadly stable with rising domestic revenues offsetting grants.

Total Revenues and Grants

(percent of GDP)

35

30

25

20

15

10

5

0

Grants and PKO financing

Domestic revenues (excl. grants \& PKO)

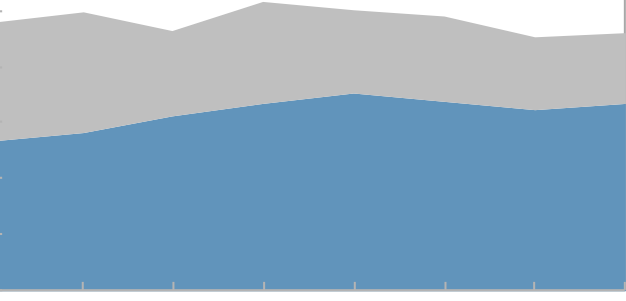

2010/11

2012/13

2014/15

$2016 / 17 \quad 2017 / 18$

..contributed to a foreseen rising external debt, which stabilized recently...

40 PV of Public and Publicly Guaranteed

35 -External Debt

30 (percent of GDP)

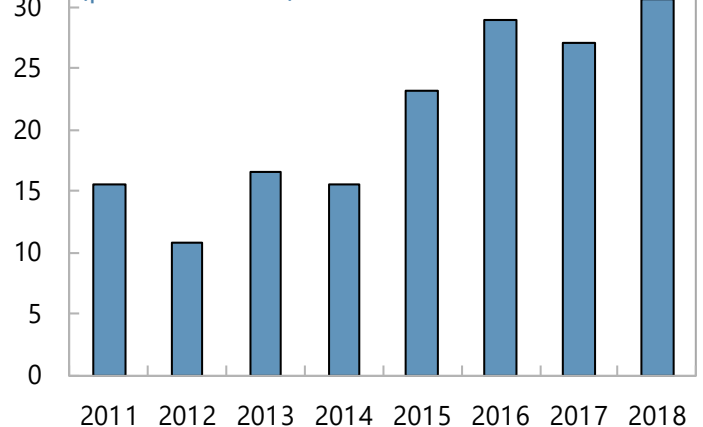

20112012201320142015201620172018
Public capital spending has remained elevated, relative to regional peers.

20 - Capital Expenditures (percent of GDP)

$\triangle E A C$ max.

$\diamond \mathrm{EAC} \min$.

15

10

0

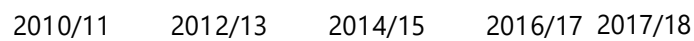

... while the fiscal deficit of the budgetary central

government has remained stable.

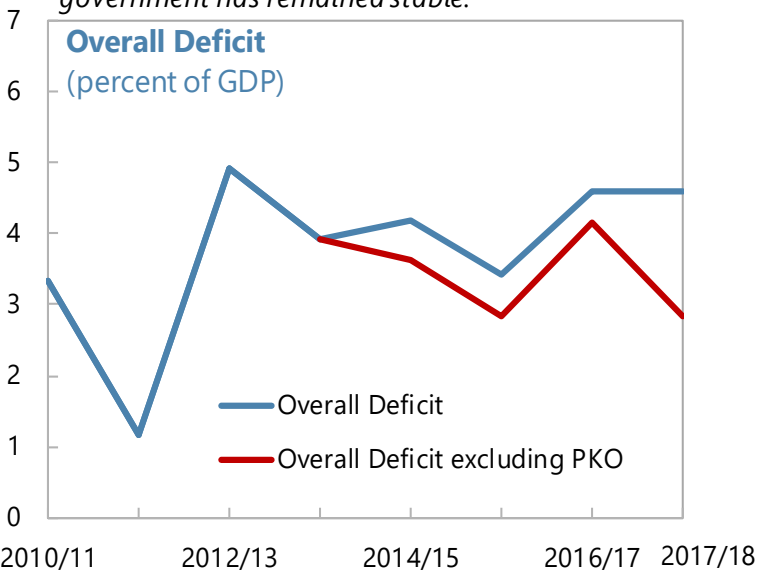

Source: Rwandan Authorities, and IMF staff estimates. 
Figure 5. Rwanda: Monetary Developments

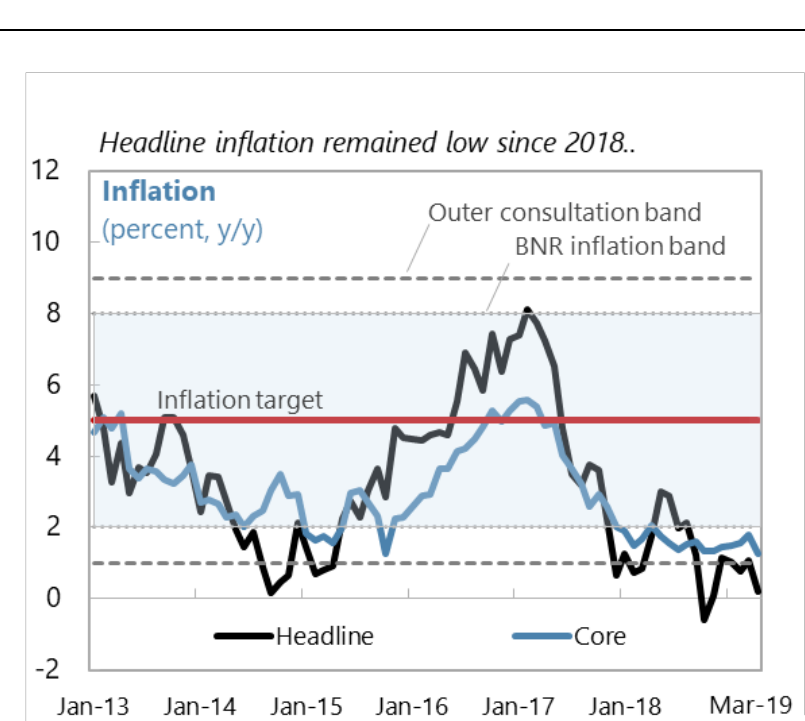

After maintaining the policy rate for six quarters, BNR 16 cut the policy rate in May 2019...

16 Policy Rate and Short Term Rates
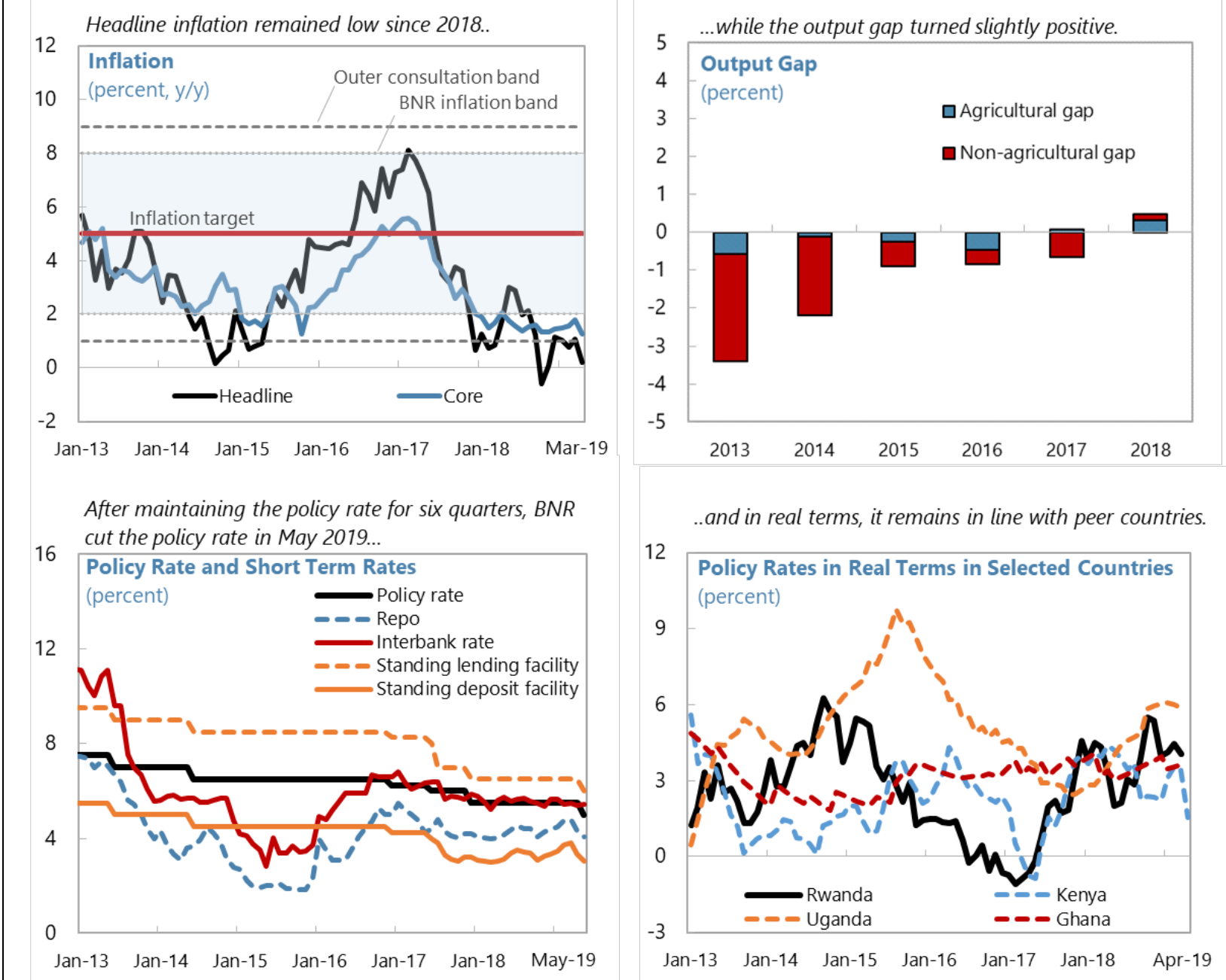

Source: Rwandan Authorities, and IMF staff estimates. 


\section{Figure 6. Rwanda: External Developments}
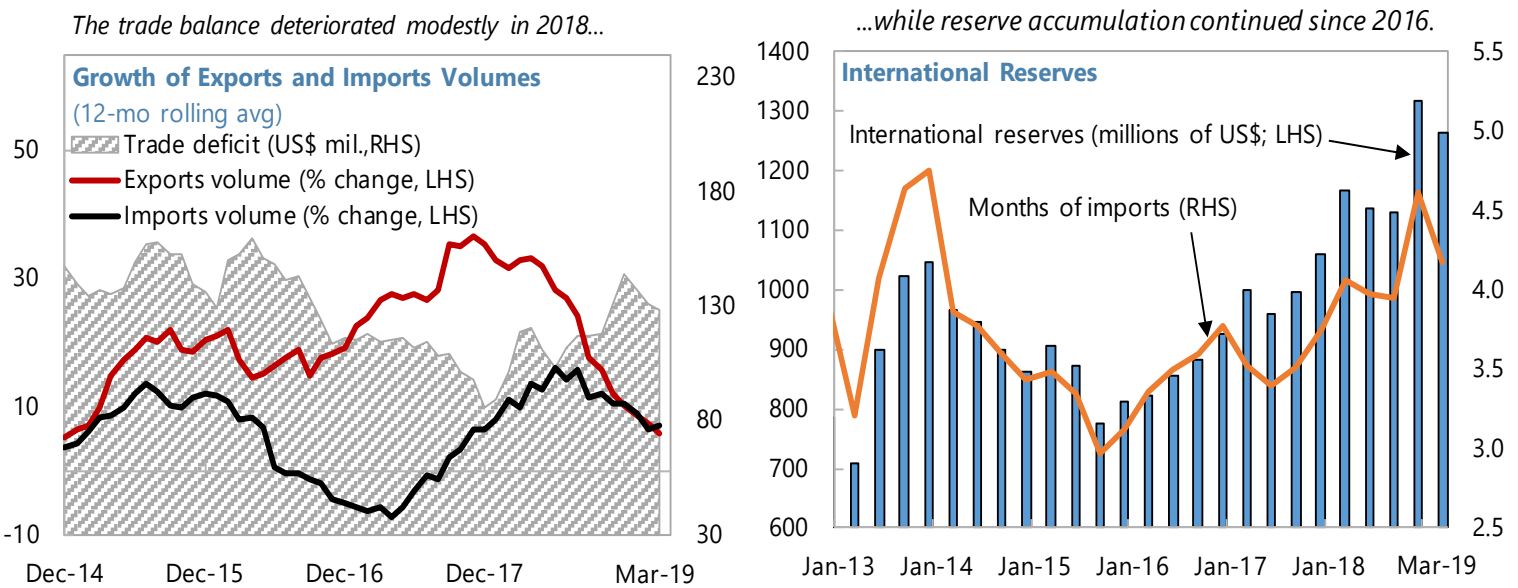

The real exchange rate continued its depreciation..

125 (indexed, March 2013=100)

EAC Real Effective Exchange Rates

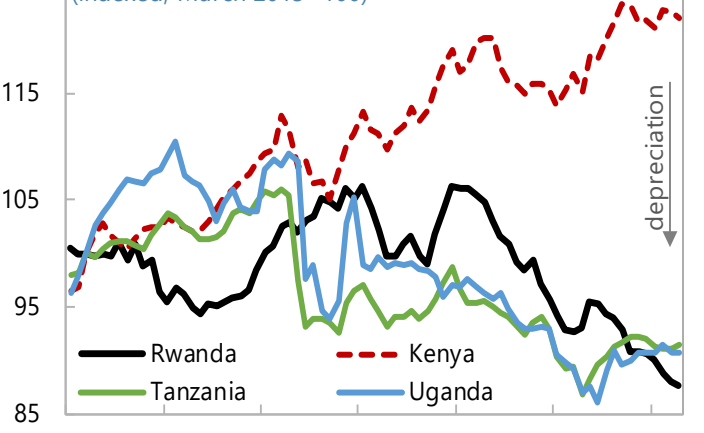

Jan-13 Jan-14 Jan-15 Jan-16 Jan-17 Jan-18 Apr-19 ... with low pressure on the nominal exchange rate since 2017.

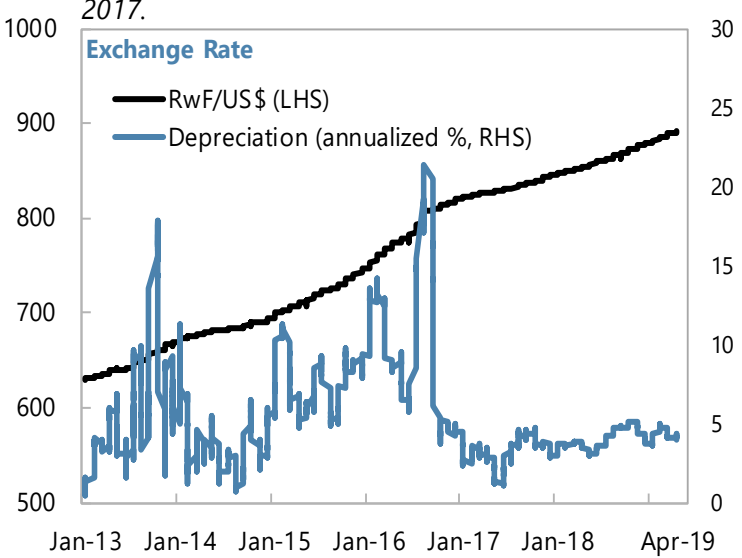

Source: Rwandan Authorities, and IMF staff estimates. 
Table 1. Rwanda: Selected Economic Indicators, 2017-23

\begin{tabular}{|c|c|c|c|c|c|c|c|}
\hline & 2017 & 2018 & 2019 & 2020 & 2021 & 2022 & 2023 \\
\hline & Act. & Prel. & Proj. & Proj. & Proj. & Proj. & Proj. \\
\hline & \multicolumn{7}{|c|}{ (Annual percentage change, unless otherwise indicated) } \\
\hline \multicolumn{8}{|l|}{ Output and prices } \\
\hline Real GDP & 6.1 & 8.6 & 7.8 & 8.1 & 8.2 & 8.0 & 7.5 \\
\hline GDP deflator & 7.3 & -0.8 & 4.2 & 5.0 & 5.0 & 5.0 & 5.0 \\
\hline CPI (period average) & 4.8 & 1.4 & 3.5 & 5.0 & 5.0 & 5.0 & 5.0 \\
\hline $\mathrm{CPI}$ (end period) & 0.7 & 1.1 & 5.0 & 5.0 & 5.0 & 5.0 & 5.0 \\
\hline Terms of trade (deterioration, -) & 1.8 & -0.7 & 0.7 & 0.1 & 0.2 & 0.4 & 0.9 \\
\hline \multicolumn{8}{|l|}{ Money and credit } \\
\hline Broad money (M3) & 12.4 & 15.6 & 19.8 & 20.0 & 17.7 & 16.9 & 15.9 \\
\hline Reserve money & 8.8 & 16.1 & 17.2 & 17.9 & 15.7 & 14.9 & 14.2 \\
\hline Credit to non-government sector & 13.9 & 10.8 & 12.8 & 14.3 & 13.9 & 13.3 & 13.4 \\
\hline M3/GDP (percent) & 23.6 & 25.3 & 27.0 & 28.5 & 29.5 & 30.5 & 31.3 \\
\hline \multirow[t]{2}{*}{ NPLs (percent of total gross loans) } & 7.6 & 6.4 & $\cdots$ & $\cdots$ & $\cdots$ & $\ldots$ & $\cdots$ \\
\hline & \multicolumn{7}{|c|}{ (Percent of GDP, unless otherwise indicated) } \\
\hline \multicolumn{8}{|l|}{ Budgetary central government } \\
\hline Total revenue and grants & 22.9 & 24.1 & 23.1 & 22.2 & 21.6 & 22.0 & 22.2 \\
\hline of which: tax revenue & 15.5 & 16.2 & 16.1 & 16.3 & 16.1 & 16.5 & 16.8 \\
\hline of which: grants & 4.7 & 4.9 & 4.8 & 3.9 & 3.4 & 3.6 & 3.7 \\
\hline Expenditure & 27.5 & 28.8 & 29.2 & 28.6 & 27.8 & 27.1 & 27.0 \\
\hline Current & 14.7 & 15.3 & 14.7 & 13.9 & 13.7 & 13.6 & 13.4 \\
\hline Capital & 10.7 & 11.5 & 12.0 & 12.3 & 12.1 & 11.5 & 11.8 \\
\hline Primary balance & -3.6 & -3.5 & -4.9 & -5.0 & -4.8 & -3.6 & -3.6 \\
\hline Overall balance & -4.7 & -4.7 & -6.1 & -6.4 & -6.2 & -5.1 & -4.8 \\
\hline excluding grants & -9.4 & -9.6 & -10.9 & -10.4 & -9.6 & -8.7 & -8.5 \\
\hline Net domestic borrowing & 0.2 & 0.0 & 2.0 & 0.8 & 1.1 & -0.3 & -0.6 \\
\hline \multicolumn{8}{|l|}{ Public debt } \\
\hline Total public debt incl. guarantees & 48.9 & 53.1 & 55.8 & 57.3 & 58.2 & 57.2 & 56.7 \\
\hline of which: external public debt & 37.9 & 41.6 & 43.4 & 44.6 & 45.5 & 45.6 & 45.8 \\
\hline PV of total public debt incl. guarantees & $\ldots$ & 41.1 & 42.5 & 42.9 & 42.7 & 41.6 & 41.2 \\
\hline \multicolumn{8}{|l|}{ Investment and savings } \\
\hline Investment & 23.8 & 24.4 & 27.7 & 28.4 & 28.2 & 27.6 & 27.8 \\
\hline Government & 10.7 & 11.5 & 12.0 & 12.3 & 12.1 & 11.5 & 11.8 \\
\hline Nongovernment & 13.1 & 12.9 & 15.7 & 16.1 & 16.1 & 16.1 & 16.1 \\
\hline Savings & 11.9 & 12.9 & 14.6 & 16.4 & 18.0 & 17.0 & 18.4 \\
\hline Government & 3.4 & 4.0 & 3.6 & 4.3 & 4.5 & 4.8 & 5.2 \\
\hline Nongovernment & 8.5 & 8.9 & 11.1 & 12.1 & 13.5 & 12.3 & 13.2 \\
\hline \multicolumn{8}{|l|}{ External sector } \\
\hline Exports (goods and services) & 21.7 & 21.4 & 21.2 & 21.4 & 22.1 & 22.1 & 22.7 \\
\hline Imports (goods and services) & 32.5 & 32.7 & 33.6 & 32.8 & 31.8 & 32.0 & 31.7 \\
\hline Current account balance (incl grants) & -7.8 & -7.9 & -9.6 & -9.4 & -7.9 & -8.1 & -7.4 \\
\hline Current account balance (excl grants) & -11.9 & -11.5 & -13.1 & -12.0 & -10.2 & -10.6 & -9.4 \\
\hline Current account balance (excl. large projects) & -7.4 & -7.4 & -9.0 & -8.3 & -7.4 & $\ldots$ & $\ldots$ \\
\hline \multicolumn{8}{|l|}{ Gross international reserves } \\
\hline In millions of US\$ & 1,163 & 1,319 & 1,428 & 1,566 & 1,637 & 1,726 & 1,867 \\
\hline In months of next year's imports & 4.5 & 4.6 & 4.7 & 4.9 & 4.7 & 4.5 & 4.5 \\
\hline \multicolumn{8}{|l|}{ Memorandum items: } \\
\hline \multicolumn{8}{|l|}{ GDP at current market prices } \\
\hline Rwanda francs (billion) & 7,600 & 8,189 & 9,199 & 10,442 & 11,866 & 13,460 & 15,197 \\
\hline US\$ (million) & 9,140 & 9,510 & $\ldots$ & $\ldots$ & $\ldots$ & $\ldots$ & $\ldots$ \\
\hline GDP per capita (US\$) & 774 & 787 & $\ldots$ & $\ldots$ & $\ldots$ & $\ldots$ & $\ldots$ \\
\hline Population (million) & 11.8 & 12.1 & 12.4 & 12.7 & 13.0 & 13.3 & 13.6 \\
\hline
\end{tabular}

\section{CInternational Monetary Fund. Not for Redistribution}


Table 2a. Rwanda: Budgetary Central Government Statement of Operations, GFSM 2014

Presentation ${ }^{1}, 2016 / 17-22 / 23$

(Billions of Rwandan francs)

\begin{tabular}{|c|c|c|c|c|c|c|c|}
\hline & $2016 / 17$ & $2017 / 18$ & $2018 / 19$ & $2019 / 20$ & $2020 / 212$ & $2021 / 22$ & $2022 / 23$ \\
\hline & Act. & Act. & Proj. & Proj. & Proj. & Proj. & Proj. \\
\hline Revenue & 1,571 & 1,767 & 2,010 & 2,136 & 2,416 & 2,680 & 3,043 \\
\hline Taxes & 1,035 & 1,180 & 1,310 & 1,460 & 1,677 & 1,925 & 2,213 \\
\hline Taxes on income, profits, and capital gains & 403.7 & 452.6 & 554.3 & 618.9 & 709.6 & 816.1 & 941.1 \\
\hline Taxes on property & 0.6 & 0.0 & 0.0 & 0.0 & 0.0 & 0.0 & 0.0 \\
\hline Taxes on goods and services & 530.0 & 605.1 & 644.7 & 718.1 & 830.3 & 955.5 & $1,097.1$ \\
\hline Taxes on international trade and transactions & 80.7 & 83.5 & 111.4 & 122.5 & 137.5 & 153.1 & 175.1 \\
\hline Other taxes & 20.0 & 38.9 & 0.0 & 0.0 & 0.0 & 0.0 & 0.0 \\
\hline Grants & 330.2 & 358.9 & 425.4 & 409.8 & 459.6 & 477.1 & 523.6 \\
\hline Current & 184.2 & 190.2 & 192.3 & 150.0 & 170.5 & 204.7 & 215.0 \\
\hline Capital & 146.0 & 168.7 & 233.1 & 259.8 & 289.1 & 272.4 & 308.6 \\
\hline Other revenue & 205.9 & 227.6 & 273.9 & 266.7 & 278.8 & 278.1 & 306.6 \\
\hline Expense (Current exp.) & 1,279 & 1,383 & 1,586 & 1,777 & 2,081 & 2,265 & 2,392 \\
\hline Compensation of employees & 237.0 & 251.7 & 285.3 & 374.8 & 404.0 & 453.1 & 519.9 \\
\hline Use of goods and services & 427.2 & 442.5 & 468.9 & 488.0 & 629.4 & 621.9 & 531.3 \\
\hline Interest & 72.2 & 91.6 & 103.0 & 128.5 & 155.8 & 177.4 & 194.8 \\
\hline To nonresidents & 36.9 & 36.9 & 47.6 & 53.7 & 63.1 & 74.6 & 99.8 \\
\hline To residents other than general government & 35.3 & 35.3 & 55.4 & 74.8 & 92.7 & 102.9 & 94.9 \\
\hline Subsidies & 86.2 & 99.5 & 182.9 & 209.2 & 237.6 & 269.7 & 305.2 \\
\hline Grants & 345.0 & 364.3 & 399.8 & 411.0 & 466.8 & 529.9 & 599.6 \\
\hline To EBUs & 45.5 & 35.6 & 39.1 & 47.7 & 54.2 & 61.5 & 69.6 \\
\hline Current & 26.1 & 23.9 & 26.2 & 23.7 & $26.9^{\top}$ & $27.0^{\top}$ & 21.6 \\
\hline of which compensation of employees & 19.9 & 21.0 & 23.0 & 18.1 & 20.5 & 23.3 & 26.4 \\
\hline Capital & 19.4 & 11.8 & 21.7 & 24.0 & 27.3 & 30.9 & 35.0 \\
\hline To Local Government & 299.4 & 299.4 & 354.8 & 363.2 & 412.6 & 468.4 & 530.0 \\
\hline Social benefits & 23.7 & 25.2 & 27.7 & 31.3 & 35.6 & 40.4 & 45.7 \\
\hline Other expense & 87.5 & 107.8 & 118.7 & 134.1 & 152.3 & 172.9 & 195.7 \\
\hline \multicolumn{8}{|l|}{ Net Operating Balance (Current balance) } \\
\hline including grants & 292.3 & 384.0 & 423.2 & 359.1 & 334.4 & 414.7 & 651.3 \\
\hline excluding grants & -37.9 & 25.1 & -2.15 & -50.7 & -125.3 & -62.4 & 127.8 \\
\hline Net acquisition of nonfinancial assets (Capital exp.) & 641.4 & 728.8 & 899.5 & 947.22 & 946.95 & $1,073.01$ & $1,362.28$ \\
\hline Foreign financed & 341.2 & 387.1 & 402.3 & 458.2 & 536.5 & 567.2 & 650.2 \\
\hline Domestically financed & 300.1 & 341.7 & 497.2 & 489.1 & 410.4 & 505.9 & 712.1 \\
\hline \multicolumn{8}{|l|}{ Net lending $(+)$ / borrowing (-) (Overall balance) } \\
\hline including grants & -349.1 & -344.7 & -476.2 & -588.1 & -612.6 & -658.3 & -710.9 \\
\hline excluding grants & -679.2 & -703.6 & -901.6 & -997.9 & $-1,072.2$ & $-1,135.4$ & $-1,234.5$ \\
\hline Net acquisition of financial assets & 26.5 & 114.9 & -20.6 & -162.2 & -32.1 & -40.7 & 1.3 \\
\hline Currency and deposits & 8.8 & 48.3 & -20.6 & -162.2 & -33.1 & -42.7 & -0.7 \\
\hline Equity and investment fund shares & -8.8 & 9.6 & 0.0 & 0.0 & 0.0 & 0.0 & 0.0 \\
\hline Loans & 26.4 & 57.0 & 0.0 & 0.0 & 0.0 & 0.0 & 0.0 \\
\hline Net incurrence of liabilities & 362.0 & 448.3 & 455.7 & 425.9 & 580.5 & 617.7 & 712.2 \\
\hline Currency and deposits & 0.0 & 0.0 & 0.0 & 0.0 & 0.0 & 0.0 & 0.0 \\
\hline Debt securities & 56.1 & 86.5 & 87.9 & 49.8 & 57.3 & 65.5 & 0.0 \\
\hline Loans & 296.3 & 326.9 & 395.0 & 406.7 & 558.4 & 592.4 & 712.2 \\
\hline Other accounts payable & 9.6 & 34.9 & -27.2 & -30.6 & -35.2 & -40.2 & 0.0 \\
\hline Statistical discrepancy & 13.6 & 11.3 & 0.0 & 0.0 & 0.0 & 0.0 & 0.0 \\
\hline \multicolumn{8}{|l|}{ Memorandum items: } \\
\hline Domestic revenue (incl. Local government) & 1,289 & 1,462 & 1,649 & 1,799 & 2,053 & 2,315 & 2,647 \\
\hline Wage bill & 413.0 & 443.3 & 502.4 & 600.5 & 660.3 & 744.2 & 849.3 \\
\hline Overall fiscal balance (incl. grants, commitment basis) & -366.7 & -411.4 & -476.2 & -588.1 & -612.6 & -658.3 & -710.9 \\
\hline Net domestic financing (excl. policy lending and OAP) & -- & -- & -66.7 & -162.2 & -32.1 & -40.7 & 62.7 \\
\hline
\end{tabular}


Table 2b. Rwanda: Budgetary Central Government Statement of Operations, GFSM 2014

Presentation ${ }^{1}, 2016 / 17-22 / 23$

(Percent of GDP)

\begin{tabular}{|c|c|c|c|c|c|c|c|}
\hline & $2016 / 17$ & $2017 / 18$ & $2018 / 19$ & $2019 / 20$ & $2020 / 21$ & $2021 / 22$ & $2022 / 23$ \\
\hline & Act. & Act. & Proj. & Proj. & Proj. & Proj. & Proj. \\
\hline Revenue & 22.0 & 22.4 & 23.1 & 21.8 & 21.7 & 21.2 & 21.2 \\
\hline Taxes & 14.5 & 14.9 & 15.1 & 14.9 & 15.0 & 15.2 & 15.4 \\
\hline Taxes on income, profits, and capital gains & 5.7 & 5.7 & 6.4 & 6.3 & 6.4 & 6.4 & 6.6 \\
\hline Taxes on property & 0.0 & 0.0 & 0.0 & 0.0 & 0.0 & 0.0 & 0.0 \\
\hline Taxes on goods and services & 7.4 & 7.7 & 7.4 & 7.3 & 7.4 & 7.5 & 7.7 \\
\hline Taxes on international trade and transactions & 1.1 & 1.1 & 1.3 & 1.2 & 1.2 & 1.2 & 1.2 \\
\hline Other taxes & 0.3 & 0.5 & 0.0 & 0.0 & 0.0 & 0.0 & 0.0 \\
\hline Social contributions & 0.0 & 0.0 & 0.0 & 0.0 & 0.0 & 0.0 & 0.0 \\
\hline Grants & 4.6 & 4.5 & 4.9 & 4.2 & 4.1 & 3.8 & 3.7 \\
\hline Current & 2.6 & 2.4 & 2.2 & 1.5 & 1.5 & 1.6 & 1.5 \\
\hline Capital & 2.0 & 2.1 & 2.7 & 2.6 & 2.6 & 2.2 & 2.2 \\
\hline Other revenue & 2.9 & 2.9 & 3.2 & 2.7 & 2.5 & 2.2 & 2.1 \\
\hline Expense (Current exp.) & 17.9 & 17.5 & 18.2 & 18.1 & 18.7 & 17.9 & 16.7 \\
\hline Compensation of employees & 3.3 & 3.2 & 3.3 & 3.8 & 3.6 & 3.6 & 3.6 \\
\hline Use of goods and services & 6.0 & 5.6 & 5.4 & 5.0 & 5.6 & 4.9 & 3.7 \\
\hline Interest & 1.0 & 1.2 & 1.2 & 1.3 & 1.4 & 1.4 & 1.4 \\
\hline To nonresidents & 0.5 & 0.5 & 0.5 & 0.5 & 0.6 & 0.6 & 0.7 \\
\hline To residents other than general government & 0.5 & 0.4 & 0.6 & 0.8 & 0.8 & 0.8 & 0.7 \\
\hline Subsidies & 1.2 & 1.3 & 2.1 & 2.1 & 2.1 & 2.1 & 2.1 \\
\hline Grants & 4.8 & 4.6 & 4.6 & 4.2 & 4.2 & 4.2 & 4.2 \\
\hline To EBUs & 0.6 & 0.5 & 0.4 & 0.5 & 0.5 & 0.5 & 0.5 \\
\hline To Local Government & 4.2 & 3.8 & 4.1 & 3.7 & 3.7 & 3.7 & 3.7 \\
\hline Social benefits & 0.3 & 0.3 & 0.3 & 0.3 & 0.3 & 0.3 & 0.3 \\
\hline Other expense & 1.2 & 1.4 & 1.4 & 1.4 & 1.4 & 1.4 & 1.4 \\
\hline \multicolumn{8}{|l|}{ Net Operating Balance (Current balance) } \\
\hline including grants & 4.1 & 4.9 & 4.9 & 3.7 & 3.0 & 3.3 & 4.5 \\
\hline excluding grants & -0.5 & 0.3 & 0.0 & -0.5 & -1.1 & -0.5 & 0.9 \\
\hline Net acquisition of nonfinancial assets (Capital exp.) & 9.0 & 9.2 & 10.3 & 9.6 & 8.5 & 8.5 & 9.5 \\
\hline Foreign financed & 4.8 & 4.9 & 4.6 & 4.7 & 4.8 & 4.5 & 4.5 \\
\hline Domestically financed & 4.2 & 4.3 & 5.7 & 5.0 & 3.7 & 4.0 & 5.0 \\
\hline \multicolumn{8}{|l|}{ Net lending $(+)$ / borrowing (-) (Overall balance) } \\
\hline including grants & -4.9 & -4.4 & -5.5 & -6.0 & -5.5 & -5.2 & -5.0 \\
\hline excluding grants & -9.5 & -8.9 & -10.4 & -10.2 & -9.6 & -9.0 & -8.6 \\
\hline Net acquisition of financial assets & 0.4 & 1.5 & -0.2 & -1.7 & -0.3 & -0.3 & 0.0 \\
\hline Currency and deposits & 0.1 & 0.6 & -0.2 & -1.7 & -0.3 & -0.3 & 0.0 \\
\hline Equity and investment fund shares & -0.1 & 0.1 & 0.0 & 0.0 & 0.0 & 0.0 & 0.0 \\
\hline Loans & 0.4 & 0.7 & 0.0 & 0.0 & 0.0 & 0.0 & 0.0 \\
\hline Net incurrence of liabilities & 5.1 & 5.7 & 5.2 & 4.3 & 5.2 & 4.9 & 5.0 \\
\hline Currency and deposits & 0.0 & 0.0 & 0.0 & 0.0 & 0.0 & 0.0 & 0.0 \\
\hline Debt securities & 0.8 & 1.1 & 1.0 & 0.5 & 0.5 & 0.5 & 0.0 \\
\hline Loans & 4.2 & 4.1 & 4.5 & 4.1 & 5.0 & 4.7 & 5.0 \\
\hline Other accounts payable & 0.1 & 0.4 & -0.3 & -0.3 & -0.3 & -0.3 & 0.0 \\
\hline Statistical discrepancy & 0.2 & 0.1 & 0.0 & 0.0 & 0.0 & 0.0 & 0.0 \\
\hline \multicolumn{8}{|l|}{ Memorandum items: } \\
\hline Overall balance (5-yr averages) & -4.5 & -4.9 & -5.2 & -5.3 & -5.4 & -5.4 & -5.2 \\
\hline Domestic revenue (incl. Local government) & 18.1 & 18.5 & 19.0 & 18.3 & 18.4 & 18.3 & 18.5 \\
\hline Wage bill & 5.8 & 5.6 & 5.8 & 6.1 & 5.9 & 5.9 & 5.9 \\
\hline Overall fiscal balance (commitment basis) & -5.1 & -5.2 & -5.5 & -6.0 & -5.5 & -5.2 & -5.0 \\
\hline Net domestic financing (excl. policy lending) & -- & -- & -0.8 & -1.7 & -0.3 & -0.3 & 0.4 \\
\hline GDP (Billions of RwF), FY basis & 7,129 & 7,895 & 8,694 & 9,821 & 11,154 & 12,663 & 14,329 \\
\hline
\end{tabular}


Table 2c. Rwanda: Budgetary Central Government Flows, FY16/17-22/231

(Billions of Rwandan francs)

\begin{tabular}{|c|c|c|c|c|c|c|c|}
\hline & $2016 / 17$ & $2017 / 18$ & $2018 / 19$ & $2019 / 20$ & $2020 / 21$ & $2021 / 22$ & $2022 / 23$ \\
\hline & Act. & Act. & Proj. & Proj. & Proj. & Proj. & Proj. \\
\hline Revenue and grants & 1,616 & 1,820 & 2,074 & 2,209 & 2,512 & 2,792 & 3,171 \\
\hline Total revenue & 1,286 & 1,462 & 1,649 & 1,799 & 2,053 & 2,315 & 2,647 \\
\hline Tax revenue & 1,104 & 1,253 & 1,403 & 1,572 & 1,807 & 2,074 & 2,385 \\
\hline Direct taxes & 468.4 & 538.7 & 607.6 & 688.2 & 789.1 & 907.6 & 1,047 \\
\hline Taxes on goods and services & 544.6 & 616.1 & 683.6 & 761.4 & 880.4 & 1,013 & 1,163 \\
\hline Taxes on international trade & 91.2 & 98.1 & 111.4 & 122.5 & 137.5 & 153.1 & 175.1 \\
\hline Non-tax revenue & 181.4 & 208.6 & 246.0 & 226.7 & 245.8 & 241.5 & 262.2 \\
\hline Of which: PKO & 128.5 & 150.1 & 167.4 & 138.6 & 150.4 & 132.5 & 143.9 \\
\hline Grants & 330.2 & 358.9 & 425.4 & 409.8 & 459.6 & 477.1 & 523.6 \\
\hline Budget grants & 184.2 & 190.2 & 192.3 & 150.0 & 170.5 & 204.7 & 215.0 \\
\hline Of which: Global Fund & 54.1 & 69.6 & 76.1 & 61.1 & 63.9 & 66.8 & -- \\
\hline Project grants & 146.0 & 168.7 & 233.1 & 259.8 & 289.1 & 272.4 & 308.6 \\
\hline Total expenditure and net lending & 1,943 & 2,188 & 2,550 & 2,797 & 3,126 & 3,453 & 3,879 \\
\hline Current expenditure & 1,070 & 1,177 & 1,301 & 1,407 & 1,560 & 1,697 & 1,931 \\
\hline Wages and salaries & 263.7 & 324.3 & 367.5 & 423.3 & 469.3 & 526.4 & 604.1 \\
\hline Purchases of goods and services & 207.4 & 216.3 & 230.9 & 235.0 & 303.4 & 333.9 & 379.8 \\
\hline Interest payments & 72.2 & 91.6 & 103.0 & 128.5 & 155.8 & 177.4 & 190.2 \\
\hline Domestic debt & 35.3 & 48.9 & 55.4 & 74.8 & 92.7 & 102.9 & 94.8 \\
\hline External debt & 36.9 & 42.7 & 47.6 & 53.7 & 63.1 & 74.6 & 95.4 \\
\hline Transfers & 366.9 & 363.3 & 398.7 & 409.8 & 457.4 & 470.3 & 537.5 \\
\hline PKO and demobilization ${ }^{2}$ & 159.4 & 181.8 & 201.1 & 210.3 & 173.8 & 188.5 & 219.7 \\
\hline of which: PKO & 128.2 & 145.8 & 160.5 & 164.3 & 124.7 & 132.5 & 154.4 \\
\hline Capital expenditure & 759 & 850 & 1,041 & 1,152 & 1,322 & 1,517 & 1,670 \\
\hline Domestic & 418.2 & 463.2 & 638.3 & 694.0 & 785.1 & 949.7 & $1,019.6$ \\
\hline Foreign $^{3}$ & 341.3 & 387.1 & 402.3 & 458.2 & 536.5 & 567.2 & 650.2 \\
\hline Of which: deposit drawdown & 34.5 & 48.0 & 0.0 & 0.0 & 0.0 & 0.0 & 0.0 \\
\hline Net lending and privatization receipts & 113.8 & 160.0 & 208.4 & 237.7 & 244.6 & 239.4 & 278.1 \\
\hline Overall balance (incl. grants, commitment basis) & -327.1 & -367.1 & -476.3 & -588.2 & -613.6 & -660.4 & -708.4 \\
\hline Change in float/arrears ${ }^{4}$ & -20.1 & -25.1 & -27.2 & -30.6 & -35.2 & -40.2 & -- \\
\hline Overall balance (incl. grants, cash basis) & -347.2 & -392.2 & -503.5 & -618.7 & -648.8 & -700.6 & -708.4 \\
\hline Financing & 347.2 & 392.2 & 503.5 & 618.7 & 648.8 & 700.6 & 708.4 \\
\hline Foreign financing (net) & 322.7 & 356.0 & 436.9 & 456.5 & 615.8 & 657.9 & 773.7 \\
\hline Drawings & 344.6 & 381.8 & 465.5 & 497.0 & 674.5 & 733.5 & 836.1 \\
\hline Budgetary loans & 183.8 & 211.5 & 296.2 & 298.6 & 427.0 & 438.7 & 494.4 \\
\hline Project loans & 160.7 & 170.4 & 169.2 & 198.4 & 247.4 & 294.8 & 341.7 \\
\hline Amortization & -21.9 & -25.8 & -28.6 & -40.5 & -58.7 & -75.6 & -63.4 \\
\hline Net domestic financing ${ }^{3}$ & 48.9 & 43.0 & 66.7 & 162.2 & 33.1 & 42.7 & -65.3 \\
\hline Net credit from banking system & 16.6 & 48.8 & 20.6 & 162.2 & 33.1 & 42.7 & -3.9 \\
\hline Nonbank sector & 32.3 & -5.9 & 46.1 & 0.0 & -- & -- & -61.4 \\
\hline Errors and omissions ${ }^{5}$ & -24.3 & -6.8 & 0.0 & 0.0 & 0.0 & 0.0 & 0.0 \\
\hline \multicolumn{8}{|l|}{ Memorandum items: } \\
\hline Primary balance (excl. grants and PKO, comm. basis) & -585 & -639 & -806 & -844 & -943 & -960 & $-1,031$ \\
\hline Overall balance excl. proj. grants and capex (comm. basis) & 286 & 314 & 331 & 304 & 419 & 584 & 653 \\
\hline
\end{tabular}


Table 2d. Rwanda: Budgetary Central Government Flows, FY16/17-22/23 (Percent of GDP)

\begin{tabular}{|c|c|c|c|c|c|c|c|}
\hline & $2016 / 17$ & $2017 / 18$ & $2018 / 19$ & $2019 / 20$ & $2020 / 21$ & $2021 / 22$ & $2022 / 23$ \\
\hline & Act. & Act. & Proj. & Proj. & Proj. & Proj. & Proj. \\
\hline Revenue and grants & 22.7 & 23.1 & 23.9 & 22.5 & 22.5 & 22.1 & 22.1 \\
\hline Total revenue & 18.0 & 18.5 & 19.0 & 18.3 & 18.4 & 18.3 & 18.5 \\
\hline Tax revenue & 15.5 & 15.9 & 16.1 & 16.0 & 16.2 & 16.4 & 16.6 \\
\hline Direct taxes & 6.6 & 6.8 & 7.0 & 7.0 & 7.1 & 7.2 & 7.3 \\
\hline Taxes on goods and services & 7.6 & 7.8 & 7.9 & 7.8 & 7.9 & 8.0 & 8.1 \\
\hline Taxes on international trade & 1.3 & 1.2 & 1.3 & 1.2 & 1.2 & 1.2 & 1.2 \\
\hline Nontax revenue & 2.5 & 2.6 & 2.8 & 2.3 & 2.2 & 1.9 & 1.8 \\
\hline Of which: PKO & 1.8 & 1.9 & 1.9 & 1.4 & 1.3 & 1.0 & 1.0 \\
\hline Grants & 4.6 & 4.5 & 4.9 & 4.2 & 4.1 & 3.8 & 3.7 \\
\hline Budget grants & 2.6 & 2.4 & 2.2 & 1.5 & 1.5 & 1.6 & 1.5 \\
\hline Project grants & 2.0 & 2.1 & 2.7 & 2.6 & 2.6 & 2.2 & 2.2 \\
\hline Total expenditure and net lending & 27.3 & 27.7 & 29.3 & 28.5 & 28.0 & 27.3 & 27.1 \\
\hline Current expenditure & 15.0 & 14.9 & 15.0 & 14.3 & 14.0 & 13.4 & 13.5 \\
\hline Wages and salaries & 3.7 & 4.1 & 4.2 & 4.3 & 4.2 & 4.2 & 4.2 \\
\hline Purchases of goods and services & 2.9 & 2.7 & 2.7 & 2.4 & 2.7 & 2.6 & 2.7 \\
\hline Interest payments & 1.0 & 1.2 & 1.2 & 1.3 & 1.4 & 1.4 & 1.3 \\
\hline Domestic debt & 0.5 & 0.6 & 0.6 & 0.8 & 0.8 & 0.8 & 0.7 \\
\hline External debt & 0.5 & 0.5 & 0.5 & 0.5 & 0.6 & 0.6 & 0.7 \\
\hline Transfers & 5.1 & 4.6 & 4.6 & 4.2 & 4.1 & 3.7 & 3.8 \\
\hline PKO and demobilization ${ }^{2}$ & 2.2 & 2.3 & 2.3 & 2.1 & 1.6 & 1.5 & 1.5 \\
\hline of which: PKO & 1.8 & 1.8 & 1.8 & 1.7 & 1.1 & 1.0 & 1.1 \\
\hline Capital expenditure & 10.7 & 10.8 & 12.0 & 11.7 & 11.8 & 12.0 & 11.7 \\
\hline Domestic & 5.9 & 5.9 & 7.3 & 7.1 & 7.0 & 7.5 & 7.1 \\
\hline Foreign $^{3}$ & 4.8 & 4.9 & 4.6 & 4.7 & 4.8 & 4.5 & 4.5 \\
\hline Of which: deposit drawdown & 0.5 & 0.6 & 0.0 & 0.0 & 0.0 & 0.0 & 0.0 \\
\hline Net lending and privatization receipts & 1.6 & 2.0 & 2.4 & 2.4 & 2.2 & 1.9 & 1.9 \\
\hline Overall balance (incl. grants, commitment basis) & -4.6 & -4.7 & -5.5 & -6.0 & -5.5 & -5.2 & -4.9 \\
\hline Change in float/arrears ${ }^{4}$ & -0.3 & -0.3 & -0.3 & -0.3 & -0.3 & -0.3 & -- \\
\hline Overall balance (incl. grants, cash basis) & -4.9 & -5.0 & -5.8 & -6.3 & -5.8 & -5.5 & -4.9 \\
\hline Financing & 4.9 & 5.0 & 5.8 & 6.3 & 5.8 & 5.5 & 4.9 \\
\hline Foreign financing (net) & 4.5 & 4.5 & 5.0 & 4.6 & 5.5 & 5.2 & 5.4 \\
\hline Drawings & 4.8 & 4.8 & 5.4 & 5.1 & 6.0 & 5.8 & 5.8 \\
\hline Budgetary loans & 2.6 & 2.7 & 3.4 & 3.0 & 3.8 & 3.5 & 3.5 \\
\hline Project loans & 2.3 & 2.2 & 1.9 & 2.0 & 2.2 & 2.3 & 2.4 \\
\hline Amortization & -0.3 & -0.3 & -0.3 & -0.4 & -0.5 & -0.6 & -0.4 \\
\hline Net domestic financing ${ }^{3}$ & 0.7 & 0.5 & 0.8 & 1.7 & 0.3 & 0.3 & -0.5 \\
\hline Net credit from banking system & 0.2 & 0.6 & 0.2 & 1.7 & 0.3 & 0.3 & -- \\
\hline Nonbank sector & 0.5 & -0.1 & 0.5 & 0.0 & 0.0 & 0.0 & -0.4 \\
\hline Errors and omissions ${ }^{5}$ & -0.3 & -0.1 & 0.0 & 0.0 & 0.0 & 0.0 & 0.0 \\
\hline \multicolumn{8}{|l|}{ Memorandum items: } \\
\hline Primary balance (excl. grants and PKO, comm. basis) & -8.2 & -8.1 & -9.3 & -8.6 & -8.5 & -7.6 & -7.2 \\
\hline Overall balance excl. proj. grants and capex (comm. basis) & 4.0 & 4.0 & 3.8 & 3.1 & 3.8 & 4.6 & 4.6 \\
\hline Overall balance (5-year avg., commitment basis) & -4.5 & -4.8 & -5.2 & -5.4 & -5.4 & -5.3 & -5.2 \\
\hline GDP (Billions of RwF), FY basis & 7,129 & 7,895 & 8,694 & 9,821 & 11,154 & 12,663 & 14,329 \\
\hline $\begin{array}{l}\text { Sources: Rwandan authorities and IMF staff estimates and pro } \\
{ }^{1} \text { Fiscal year runs from July to June. } \\
2 \text { Includes peacekeeping operations, spending on demobilisa } \\
{ }^{3} \text { 2016/17 and } 2017 / 18 \text { foreign-financed capital spending inc } \\
{ }^{4} \text { A negative sign indicates a reduction. } \\
{ }^{5} \text { A negative number implies an overestimate of financing. }\end{array}$ & $\begin{array}{l}\text { jections. } \\
\text { ton/reinteg } \\
\text { luded depo }\end{array}$ & $\begin{array}{l}\text { ration, and } \\
\text { sit drawdov }\end{array}$ & $\begin{array}{l}\text { yenocide re } \\
\text { n, accumul }\end{array}$ & $\begin{array}{l}\text { lief. } \\
\text { ated in prev }\end{array}$ & ious years. & & \\
\hline
\end{tabular}


Table 3. Rwanda: Monetary Survey, 2017-20

(Billions of Rwandan francs, unless otherwise indicated)

\begin{tabular}{|c|c|c|c|c|c|c|}
\hline & \multirow{2}{*}{$\begin{array}{l}2017 \\
\text { Dec. }\end{array}$} & \multirow{2}{*}{$\begin{array}{l}2018 \\
\text { Dec. }\end{array}$} & \multicolumn{2}{|c|}{2019} & \multicolumn{2}{|c|}{2020} \\
\hline & & & Jun. & Dec. & Jun. & Dec. \\
\hline & Act. & Act. & Proj. & Proj. & Proj. & Proj. \\
\hline \multicolumn{7}{|l|}{ Monetary authorities } \\
\hline Net Foreign Assets ${ }^{1}$ & 749 & 902 & 863 & 980 & 871 & 1,121 \\
\hline Net domestic assets & -420 & -519 & -447 & -532 & -383 & -593 \\
\hline Domestic credit & -249 & -326 & -255 & -340 & -197 & -412 \\
\hline Other items (net; asset +) & -171 & -194 & -192 & -191 & -186 & -181 \\
\hline Reserve money $^{2}$ & 329 & 382 & 415 & 448 & 488 & 528 \\
\hline \multicolumn{7}{|l|}{ Commercial banks } \\
\hline Net foreign assets & 54 & 167 & 138 & 110 & 110 & 110 \\
\hline Reserves & 165 & 197 & 214 & 231 & 252 & 273 \\
\hline Net credit from BNR & 36 & 56 & 165 & 213 & 86 & 318 \\
\hline Domestic credit & 1,782 & 1,984 & 2,075 & 2,227 & 2,562 & 2,539 \\
\hline Government (net) & 297 & 290 & 298 & 318 & 476 & 374 \\
\hline Public enterprises & 46 & 95 & 93 & 90 & 88 & 85 \\
\hline Private sector & 1,439 & 1,599 & 1,684 & 1,818 & 1,999 & 2,080 \\
\hline Other items (net; asset +) & -410 & -518 & -517 & -517 & -517 & -517 \\
\hline Deposits & 1,626 & 1,886 & 2,075 & 2,263 & 2,493 & 2,723 \\
\hline \multicolumn{7}{|l|}{ Monetary survey } \\
\hline Net foreign assets & 803 & 1,069 & 1,001 & 1,090 & 981 & 1,231 \\
\hline Net domestic assets & 989 & 1,003 & 1,275 & 1,391 & 1,748 & 1,747 \\
\hline Domestic credit & 1,569 & 1,714 & 1,985 & 2,099 & 2,451 & 2,444 \\
\hline Government & 58 & -3 & 191 & 179 & 353 & 268 \\
\hline Public enterprises & 46 & 95 & 93 & 90 & 88 & 85 \\
\hline Private sector & 1,464 & 1,622 & 1,702 & 1,830 & 2,011 & 2,092 \\
\hline Other items (net; asset + ) & -581 & -711 & -710 & -708 & -703 & -697 \\
\hline Broad money & 1,792 & 2,072 & 2,276 & 2,481 & 2,729 & 2,978 \\
\hline Year on Year Growth & \multicolumn{6}{|c|}{ (Percent) } \\
\hline Broad money & 12.4 & 15.6 & 17.2 & 19.8 & 19.9 & 20.0 \\
\hline Reserve money & 8.8 & 16.1 & 11.5 & 17.2 & 17.6 & 17.9 \\
\hline Net foreign assets & 8.6 & 33.0 & 25.0 & 2.0 & -2.0 & 13.0 \\
\hline Credit to the private sector & 13.9 & 10.8 & 14.1 & 12.8 & 18.1 & 14.3 \\
\hline \multicolumn{7}{|l|}{ Memorandum items: } \\
\hline Velocity (eop) & 4.2 & 4.0 & 3.9 & 3.7 & 3.6 & 3.5 \\
\hline Money multiplier & 5.4 & 5.5 & 5.5 & 5.5 & 5.6 & 5.6 \\
\hline
\end{tabular}

Sources: National Bank of Rwanda (NBR) and IMF staff estimates and projections.

${ }^{1}$ For program purposes NFA are shown at program exchange rates.

${ }^{2}$ Reserve money as an assessment criteria is measured as the average of the months in the quarter. The actual reserve money is measured as the daily average of the three months in the 


\begin{tabular}{|c|c|c|c|c|c|c|c|}
\hline \multicolumn{8}{|c|}{$\begin{array}{l}\text { Table 4. Rwanda: Balance of Payments, 2017-23 } \\
\text { (Millions of U.S. Dollars, unless otherwise indicated) }\end{array}$} \\
\hline & $\overline{\square \square \square \square}$ & $\square \square \square \square$ & $\overline{\square \square \square \square}$ & $\square \square \square \square$ & $\square \square \square \square$ & 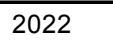 & $\square \square \square$ \\
\hline & 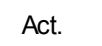 & $\square \square$ & $\square \square(\mathbb{m}$ & $\square \square(\mathbb{Q}$ & $\square \square(\mathbb{Q}$ & $\square \square(\mathbb{Q}$ & $\square \square(\mathbb{l}$ \\
\hline Current account balance (incl. official transfers) & -709 & -747 & -975 & $-1,038$ & -956 & $-1,058$ & $-1,070$ \\
\hline Trade balance & -829 & -907 & $-1,044$ & $-1,031$ & -997 & $-1,111$ & $-1,151$ \\
\hline Exports (f.o.b.) & 1,050 & 1,126 & 1,218 & 1,327 & 1,481 & 1,678 & 1,853 \\
\hline Of which: coffee and tea & 148.4 & 159.2 & 162.0 & 175.7 & 197.6 & 218.2 & 237.9 \\
\hline Of which: minerals & 125.0 & 142.2 & 170.2 & 194.1 & 226.4 & 256.8 & 291.3 \\
\hline Imports (f.o.b.) & 1,879 & 2,032 & 2,261 & 2,357 & 2,478 & 2,789 & 3,003 \\
\hline Of which: capital goods & 495.9 & 547.6 & 613.2 & 613.9 & 661.9 & 827.2 & 884.5 \\
\hline Of which: Energy goods & 201.7 & 246.2 & 229.8 & 247.8 & 264.2 & 295.6 & 331.3 \\
\hline Services (net) & -157.0 & -162.5 & -225.5 & -229.0 & -162.9 & -184.4 & -158.7 \\
\hline Credit & 930 & 913 & 948 & 1,041 & 1,181 & 1,232 & 1,414 \\
\hline Of which: tourism receipts & 369.6 & 374.1 & 404.0 & 444.4 & 511.0 & 521.3 & 615.1 \\
\hline Debit & 1,087 & 1,076 & 1,173 & 1,270 & 1,344 & 1,416 & 1,573 \\
\hline Income & -319.6 & -334.8 & -385.6 & -412.0 & -428.5 & -451.3 & -449.2 \\
\hline Of which: interest on public debt ${ }^{1}$ & -73.8 & -79.0 & -83.4 & -97.0 & -97.0 & -100.7 & -94.1 \\
\hline Current transfers (net) & 596.4 & 657.0 & 679.3 & 633.6 & 632.3 & 688.2 & 688.4 \\
\hline Private & 220.7 & 311.1 & 318.6 & 341.0 & 362.5 & 365.8 & 399.1 \\
\hline Public & 375.7 & 346.0 & 360.7 & 292.5 & 269.8 & 322.4 & 289.4 \\
\hline Capital and financial account balance & 776 & 950 & 1,085 & 1,199 & 1,063 & 1,194 & 1,259 \\
\hline Capital account & 189.7 & 244.5 & 260.2 & 284.6 & 290.8 & 282.4 & 311.4 \\
\hline Financial account & 586.3 & 705.1 & 824.5 & 914.3 & 772.5 & 911.2 & 947.6 \\
\hline Direct investment & 255.0 & 287.6 & 298.5 & 310.9 & 258.0 & 232.9 & 277.2 \\
\hline Public sector capital & 345.5 & 481.9 & 437.5 & 632.9 & 510.4 & 641.8 & 632.4 \\
\hline Long-term borrowing ${ }^{2}$ & 406.0 & 550.4 & 500.3 & 768.7 & 740.9 & 766.6 & $1,299.0$ \\
\hline Scheduled amortization, excl IMF & -60.4 & -68.5 & -62.8 & -135.8 & -230.5 & -124.9 & -666.7 \\
\hline Other capital ${ }^{3}$ & -14.3 & -64.5 & 88.6 & -29.5 & 4.1 & 36.5 & 38.1 \\
\hline Of which: commercial banks NFA (increase -) & 33.4 & -126.1 & 65.0 & 0.0 & 0.0 & 0.0 & 0.0 \\
\hline Net errors and omissions & 26.1 & -69.3 & 0.0 & 0.0 & 0.0 & 0.0 & 0.0 \\
\hline Overall balance & 92.6 & 133.3 & 109.3 & 160.9 & 107.4 & 135.5 & 189.0 \\
\hline Financing & -92.6 & -133.3 & -109.3 & -160.9 & -107.4 & -135.5 & -189.0 \\
\hline Reserve assets (increase -) & -161.9 & -155.8 & -109.3 & -138.1 & -70.1 & -89.3 & -141.4 \\
\hline Net credit from the IMF & 74.9 & 24.3 & 0.0 & -22.9 & -37.3 & -46.1 & -47.6 \\
\hline \multicolumn{8}{|l|}{ Memorandum items: } \\
\hline Current account deficit (percent of GDP) ${ }^{4}$ & -7.8 & -7.9 & -9.6 & -9.4 & -7.9 & -8.1 & -7.4 \\
\hline Trade balance (percent of GDP) & -9.1 & -9.5 & -10.2 & -9.3 & -8.3 & -8.5 & -8.0 \\
\hline Gross official reserves & 1,163 & 1,319 & 1,428 & 1,566 & 1,637 & 1,726 & 1,867 \\
\hline in months of prospective imports of G\&S & 4.5 & 4.6 & 4.7 & 4.9 & 4.7 & 4.5 & 4.5 \\
\hline \multicolumn{8}{|c|}{ Sources: Rwandan authorities and IMF staff estimates and projections. } \\
\hline \multicolumn{8}{|l|}{${ }^{1}$ Including interest due to the IMF. } \\
\hline \multicolumn{8}{|c|}{${ }^{2}$ Includes central government project and budget loans, and borrowing by Rwandair, and Bugesera. } \\
\hline \multicolumn{8}{|c|}{${ }^{3}$ Other capital includes long-term private capital, commercial credit, change in NFA of commercial banks, and unrecorded imports. } \\
\hline
\end{tabular}


Table 5. Rwanda: Financial Soundness Indicators: December 2015-December 2018

\begin{tabular}{|c|c|c|c|c|c|c|c|c|}
\hline & \multirow{2}{*}{$\begin{array}{l}2015 \\
\text { Dec. }\end{array}$} & \multirow{2}{*}{$\begin{array}{l}2016 \\
\text { Dec. }\end{array}$} & \multicolumn{2}{|c|}{2017} & \multicolumn{4}{|c|}{2018} \\
\hline & & & Jun. & Dec. & Mar. & Jun. & Sep. & Dec. \\
\hline & \multicolumn{7}{|c|}{ (Percent) } & \\
\hline $\begin{array}{l}\text { Capital adequacy } \\
\text { Regulatory capital to risk-weighted assets }\end{array}$ & 19.9 & 20.0 & 19.2 & 20.0 & 19.5 & 19.7 & 20.8 & 21.2 \\
\hline Capital to assets & 22.5 & 21.9 & 20.8 & 21.4 & 21.1 & 21.4 & 22.6 & 22.9 \\
\hline Off balance sheet items/total qualifying capital & 302.7 & 304.9 & 303.7 & 298.7 & 303.7 & 297.5 & 276.1 & 315.7 \\
\hline Insider loans/core capital & 4.0 & 2.4 & 5.2 & 6.0 & 5.9 & 5.9 & 5.7 & 5.6 \\
\hline Large exposure/core capital & 112.6 & 149.5 & 162.2 & 169.6 & 164.7 & 174.9 & 136.1 & 134.8 \\
\hline \multicolumn{9}{|l|}{ Asset quality } \\
\hline NPLs/gross Loans & 6.2 & 7.6 & 8.2 & 7.6 & 6.8 & 6.9 & 7.2 & 6.4 \\
\hline NPLs net/gross loans & 5.2 & 5.7 & 6.4 & 6.6 & 5.5 & 5.2 & 6.1 & 5.5 \\
\hline Provisions/NPLs & 46.2 & 42.7 & 44.9 & 46.7 & 59.2 & 67.2 & 64.2 & 68.2 \\
\hline Earning assets/total asset & 83.1 & 82.4 & 81.9 & 83.0 & 78.9 & 80.8 & 84.6 & 84.8 \\
\hline Large exposures/gross loans & 23.4 & 31.0 & 33.6 & 33.6 & 34.2 & 34.8 & 29.6 & 32.0 \\
\hline \multicolumn{9}{|l|}{ Profitability and earnings } \\
\hline Return on average assets & 2.1 & 1.7 & 1.7 & 1.1 & 1.3 & 1.6 & 1.7 & 1.9 \\
\hline Return on average equity & 11.2 & 8.8 & 9.6 & 6.2 & 7.9 & 9.6 & 10.2 & 11.2 \\
\hline Net interest margin & 9.2 & 10.4 & 9.9 & 8.8 & 9.8 & 9.6 & 9.5 & 9.0 \\
\hline Cost of deposits & 3.2 & 3.7 & 3.5 & 3.4 & 3.5 & 3.5 & 3.5 & 3.4 \\
\hline Cost to income & 81.1 & 83.1 & 81.1 & 85.1 & 82.5 & 81.0 & 79.7 & 78.4 \\
\hline Overhead to income & 46.8 & 49.9 & 48.2 & 48.4 & 45.3 & 45.5 & 45.6 & 45.0 \\
\hline \multicolumn{9}{|l|}{ Liquidity } \\
\hline Short term gap & 8.1 & 2.3 & 6.8 & 5.9 & 4.9 & 6.6 & 4.3 & 3.6 \\
\hline Liquid assets/total deposits & 45.8 & 42.5 & 44.0 & 46.7 & 49.4 & & & \\
\hline Interbank borrowings/total deposits & 18.1 & 20.4 & 20.0 & 23.0 & 23.6 & 21.9 & 22.3 & 21.5 \\
\hline BNR borrowings/total deposits & 0.0 & 0.0 & 0.0 & 0.0 & 0.5 & 0.0 & 0.0 & 0.0 \\
\hline Gross loans/total deposits & 101.7 & 109.1 & 108.4 & 108.9 & 106.5 & 109.0 & 106.3 & 107.2 \\
\hline \multicolumn{9}{|l|}{ Market sensitivity } \\
\hline Forex exposure/core capital1 & -5.7 & -7.0 & -6.1 & -7.8 & -4.5 & -6.2 & -10.1 & -5.6 \\
\hline Forex loans/Forex deposits & 47.7 & 38.8 & 42.5 & 46.7 & 49.4 & 45.4 & 40.2 & 41.1 \\
\hline Forex assets/Forex liabilities & 81.7 & 81.6 & 82.6 & 80.4 & 76.5 & 82.0 & 79.3 & 82.8 \\
\hline
\end{tabular}

Source: National Bank of Rwanda. 
Table 6. Rwanda: Schedule of Reviews Under the Policy Coordination Instrument, 2019-22

\begin{tabular}{lll}
\hline Program Review & Test Date & Review Date \\
\hline Board discussion of a PCI request & & June 28, 2019 \\
First Review & June 30, 2019 & December 15, 2019 \\
Second Review & December 31, 2019 & June 15, 2020 \\
Third Review & June 30, 2020 & December 15, 2020 \\
Fourth Review & December 31, 2020 & June 15, 2021 \\
Fifth Review & June 30, 2021 & December 15, 2021 \\
Sixth Review & December 31, 2021 & June 15, 2022 \\
\hline Source: IMF stff & &
\end{tabular}

Source: IMF staff. 


\section{Annex I. Implementation of Key Policy Recommendations from the 2017 Article IV Consultation}

\section{Key Policy Recommendations and Their Status}

Improved External Position: Maintain exchange rate flexibility and rebuild official foreign exchange reserve buffers for a sustainable and resilient external position;

Status: Gross reserves have increased from US\$1.0 billion at end-2016 to US $\$ 1.3$ billion or 4.1 months of imports as of end-December 2018. IMF's 2017 Annual Report on Exchange Arrangements and Exchange Restrictions published on April 30, 2018 classifies Rwanda's franc as a "crawl-like arrangement." The 2019 external assessment finds that the REER is in line fundamentals, after a nominal exchange rate depreciation in 2018.

Fiscal Policy: Build on progress in boosting revenue collection, to provide space for strategic public investment and reduce aid dependence. Ensuring tax incentives to promote domestic production are well-targeted, consistent with overall fiscal objectives.

Status: Tax revenue collection as a share of GDP rose slightly from 15.7 percent of GDP at end2016 to 15.9 percent of GDP at end-2018. Nevertheless, VAT-C Efficiency and CIT productivities remain low, in part due to fiscal incentives to attract private sector investment. The authorities have sought TA on tax expenditure analysis from various development partners to inform where reforms are needed.

Fiscal/Monetary Policy mix: Maintain agreed fiscal and monetary stance, and reconsider monetary stance in the second half of 2017 based on developments in inflation and growth projections.

Status: Agreed fiscal and monetary quantitative program targets have been met. Deviations from fiscal targets reflected increased availability of concessional financing for development needs. Headline inflation has remained below authorities' medium-term target since May 2016.

Monetary Policy Framework: In the transition to an interest-based monetary policy framework, place priority on exchange rate flexibility, functioning money market tools, and providing clear signals about the policy stance to guide inflation expectations

Status: On December 21, 2018, the central bank formally announced its move to a new interest rate-based monetary policy framework, which took effect as of January 1,2019 . Since June 2016, interbank rates have remained close to the policy rate. As of January 1, 2019, the interest rate corridor was reset to 100 basis points above the policy rate and 200 basis points below. The February 7, 2019 MPC statement gave a clear indication about its inflation forecast, and its rationale for choosing to leave the policy rate unchanged despite inflation remaining below the targeted corridor. 


\section{Annex II. Spending Needs for Reaching the SDG Goals ${ }^{1}$}

This paper estimates additional spending required in the year 2030 for achieving meaningful outcomes on the SDGs in the areas of education, health, roads, electricity, and water and sanitation for Rwanda. The main finding is that delivering on the SDG agenda in these areas will require additional spending in 2030 of about 20 percent of GDP. ${ }^{2}$ The Rwanda case study indicates that education is the sector with the higher spending needs (7 percent of 2030 GDP). A costing of all sectors underlying the NST and SDGs would provide a larger estimate, but these should be significantly less costly. This case study was a collaborative effort with the Rwandan authorities and development partners, particularly UNDP, World Bank, UK DFID, Enabel, and UNICEF.

\section{A. Background}

1. The Rwandan National Strategy for Transformation (NST) has been structured to align with the Sustainable Development Goals (SDGs). SDG targets have been domesticated into the NST, which runs from 2018-24 and is part of a larger Vision 2050, with the help of development partners. Line ministries have already produced comprehensive sectoral strategies and preliminary estimates of sectoral spending needs for achieving the NST and are in close dialogue with development partners (UNICEF, UKDFID, Enabel, the World Bank, WHO) to refine these estimates and prioritize their action plan. However, the sector-specific costing estimates have not been reconciled with top-down multiyear rough budget estimates of NST implementation.

\section{B. SDG Performance}

2. Rwanda has delivered impressive development outcomes in the past 20 years, allowing the country to be broadly on par with-and in some instances, outperforming-other LowIncome and Developing Economies (LIDCs) with respect to the SDG performance indicators (Figure 1). In health indicators, Rwanda outperforms the median LIDC. For instance, both infant and maternal mortality rates cut to 1/5th between 2000 and 2016. Use of home-grown approaches and new technology have enabled efficient use of public resource to improve healthcare access and delivery. ${ }^{3}$ By contrast, education performance is rated as on par with the median peer LIDC. Although since 2013 primary gross enrollment rate (GER) have been increased to 100 percent and the rate of out-of-school children is low, the secondary GER barely reaches 40 percent. Similarly,

\footnotetext{
${ }^{1}$ Primary author was D. Prady (FAD), with contributions from L. Redifer, E. Alper, and A. Thomas (all AFR). Two joint AFR-FAD SDG costing missions took place in Kigali, Rwanda: the first one on March 14-23, and the second on June 18-22. Each time the mission had high-level and technical meetings with Education, Health, Infrastructure and Finance Ministries; it also organized several meetings with Development Partners (UNDP, World Bank, UK DFID, USAID, SDG Center for Africa, Enabel, UNICEF).

2 These estimates presented in this annex follow the methodology laid out in the 2019 Staff Discussion Note "Fiscal Policy and Development: Human, Social, and Physical Investments for the SDGs" and refers to additional spending in the year 2030 compared to what Rwanda is currently spending. Therefore, the estimates reported are not cumulative spending up to 2030. The methodology is silent about the spending path during the period up to 2030

${ }^{3}$ For example, the government is using health clinics as the first line for service delivery in rural areas, while also signing a contract to deliver blood supplies via drone. Also, using artificial intelligence as a health diagnostic tool is being customized and tested on a large scale in the country.
} 
while water and sanitation and infrastructure quality are ranked well, reliable access remains a challenge. In energy, despite a current oversupply of energy on the grid, the goal of 100 percent access in rural areas (via solar panels) will be challenging.

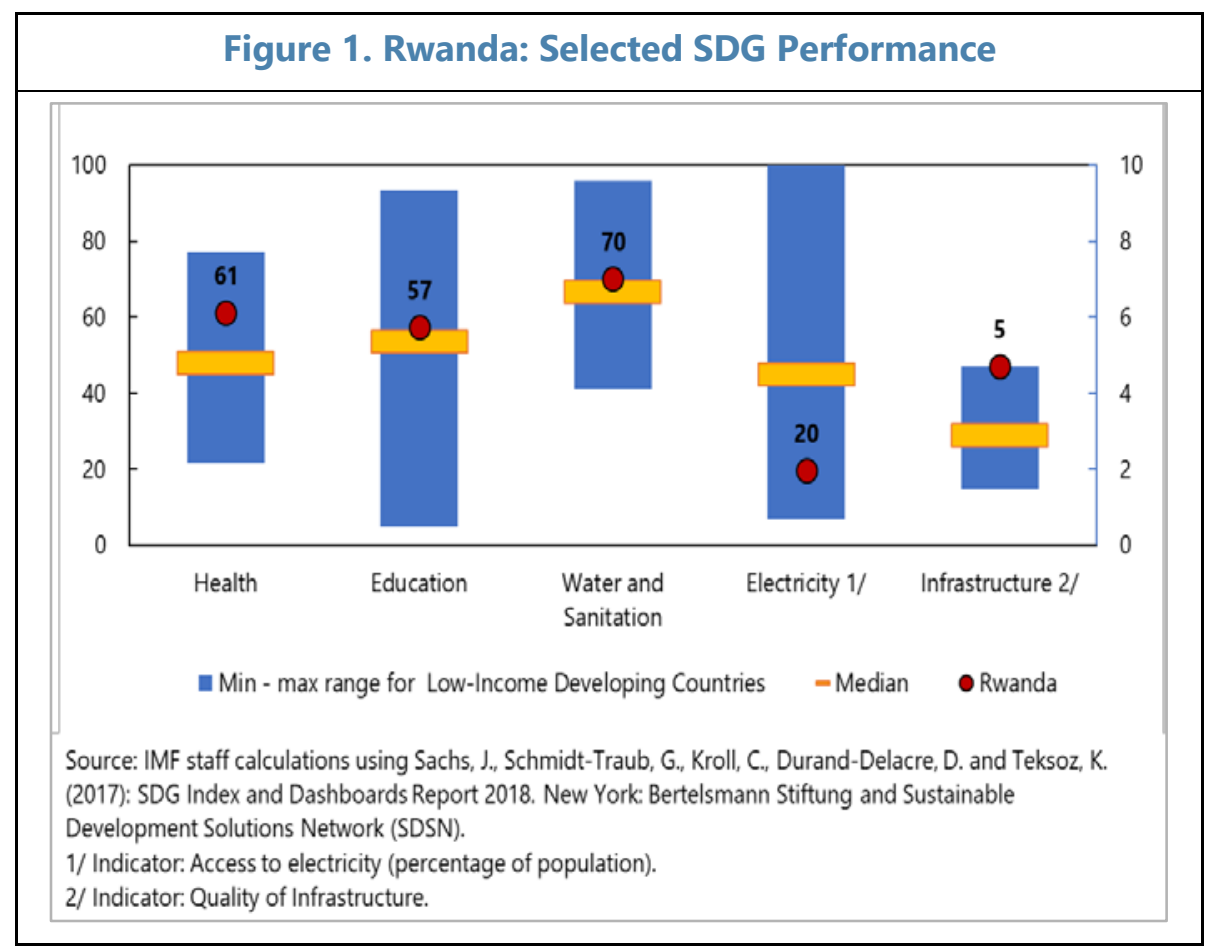

\section{Despite good progress to date, meeting the SDGs in a meaningful way will be} challenging, with remaining gaps between NST goals and current basic service delivery. For instance, as of 2016, 38 percent of children still suffered from stunting and access to health facilities with qualified staff remained low; in addition to low aforementioned secondary gross enrollment rates, the quality of education is still a serious problem; and only 13 percent of the population has access to safely managed sanitation (which includes containment through safe collection, treatment, and end use/disposal) and 43 percent to electricity. ${ }^{4}$

4. It is important first to establish clear baselines by which progress can be measured. Line ministries and development partners have been working together to gather the data necessary to assess where the country currently stands with respect to each SDG target (i.e., baseline data). In education, for example, the authorities and UNICEF and UKDFID have established a common template to refine baseline data and goals in order to cost their strategy. In health, the authorities have hired a consultant to customize the WHO costing tool "OneHealth" to the Rwandan context. In infrastructure, the authorities have liaised with UNICEF (water) and the World Bank and MIT (electricity) to produce cost estimates of universal access, according to various scenarios differentiating the amount and quality of access.

\footnotetext{
${ }^{4}$ Rwanda does not participate in regional or international learning assessments.
} 


\section{Assessing Spending Needs}

\section{Education}

5. To spend on a commensurate level with the median high performing comparable peer country on education, Rwanda would need to increase total education spending by $\mathbf{7}$ percent of GDP (Table 1). ${ }^{5}$ Rwanda's annual public spending on education-at 3.6 percent of GDP-is lower than in other peer countries (GDP less than 3,000 US\$ per capita). Performance in education, as assessed by SDG index 3 (Sachs and others, 2017), reaches 59, just above the median among peers (Table 1), but this mainly reflects access rates rather than quality of education. Current spending is low, reflecting the fact that student-to-teacher ratios are higher than that observed in peer countries with better performance in education (46 versus 15 students per teacher respectively, Table 1). In terms of composition, Rwanda spends only about 30 percent of its education budget on teacher compensation vs. 45 percent in higher-performing comparable countries (Table 1).

\begin{tabular}{|c|c|c|c|c|c|}
\hline Median statistics & Peers & $\begin{array}{c}\text { Peers with } \\
\text { SDG } 4 \text { index }< \\
80\end{array}$ & $\begin{array}{l}\text { Peers with } \\
\text { SDG } 4 \text { index } \\
>=80\end{array}$ & $\begin{array}{c}\text { Rwanda } \\
\text { - } \\
2016\end{array}$ & $\begin{array}{c}\text { Rwanda } \\
- \\
2030\end{array}$ \\
\hline Number of countries & 54 & 47 & 7 & - & - \\
\hline GDP per capita (current USD) & 1,058 & 990 & 2,111 & 703 & 1,427 \\
\hline Enrollment rate (pre-primary to tertiary) & $49 \%$ & $45 \%$ & $59 \%$ & $51 \%$ & $73 \%$ \\
\hline Student-age population (\% of total pop) & $55 \%$ & $56 \%$ & $39 \%$ & $56 \%$ & $47 \%$ \\
\hline Student to teacher & 31 & 32 & 15 & 46 & 15 \\
\hline Teacher salary to GDP per capita ratio & 2.5 & 2.7 & 2.1 & 1.7 & 2.1 \\
\hline Teacher compensation (\% total spending) & 55 & 55 & 45 & 29 & 45 \\
\hline Other current and capital cost (\% of total spending) & 45 & 45 & 55 & 71 & 55 \\
\hline Public education spending to GDP (\%) & 4.4 & 4 & 5.6 & 3.6 & 10.7 \\
\hline Spending per student (current USD) & 155 & 137 & 554 & 89 & 441 \\
\hline SDG4 score (0 to 100$)$ & 55 & 52 & 86 & 59 & \\
\hline
\end{tabular}

6. The NST strategy for education is an important step towards filling this gap, however, this analysis suggests that more would be needed (Figure 2). By 2030, the Rwandan government plans nearly to double current spending in education, to reach 6.3 percent of GDP, or US\$254 per student per year (Figure 2). The bulk of the extra spending is planned for hiring more teachers to reduce the student-to-teacher ratio, especially at the primary level, where repetition rates are higher. However, to reach the level of peer countries with better performance by 2030 , an additional

\footnotetext{
${ }^{5}$ Peers are countries with GDP per capita lower or equal to US $\$ 3,000$.
} 
4 percent of GDP on top of that would be needed, i.e., 10.7 percent of GDP or around US $\$ 440$ per student (Figure 2).

Figure 2. Education Spending Needs-Comparison of Authorities and IMF Estimates (Current USD per student and percent of GDP)

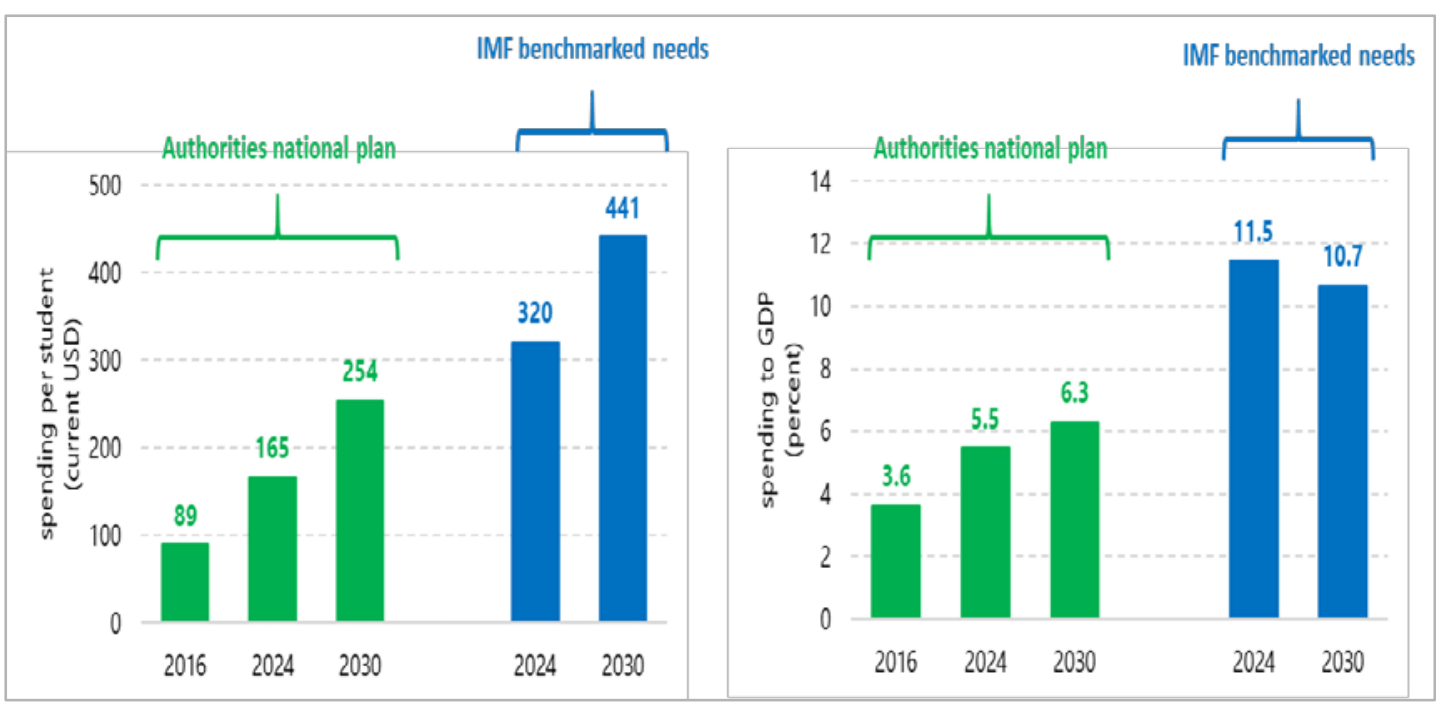

Source: IMF staff calculations on Authorities' NST and World Bank and UN data.

Note: Blue bars are IMF estimates of what Rwanda would need to spend in order to achieve a high performance in education, either as early as 2024 or in 2030 . They show two point-estimates of spending needs and do not illustrate a spending path.

\section{Health}

\section{With a similar level of per capita spending, Rwanda achieves better outcomes than the} median peer, but more is needed to reach the top level of performance. Rwanda spends about US $\$ 58$ per capita per year on health and is assessed to have achieved an SDG 3 index of 62 , higher than the median of 49 peer countries (Table 2). While its current mix of doctors vs. other health workers has allowed for this relatively good outcome, this analysis suggests that an overall increase in the number of health workers (by another $2 / 3$ ), mostly doctors, would be needed to bring Rwanda to the level of the best performing peer countries (Table 2). These personnel increases would imply that Rwanda should scale up its spending in health by 2.2 percentage points of GDP.

\section{Again, the NST sector-specific strategy will be a crucial step to narrow the gap, but} more would be needed to achieve the best outcomes. By 2024, the government plans to increase per capita public spending on health by more than one-third (36 percent), from US $\$ 38$ to US $\$ 52$ per capita per year (Figure 3). However, this analysis suggests that per capita public spending increases should double to achieve the best outcomes. More granular data on spending composition (in Rwanda and comparator countries, e.g. for compensation vs. other spending) would enable better analysis on the desirable allocation of such spending. It should be noted that the 2016 private spending estimate of 2.8 percent of GDP is unanimously seen as too high by the authorities and all development partners, including local WHO representatives. Therefore, the comparison in Figure 3 focuses on public spending needs. 
Table 2. Median Reference Values for Health in Peer Countries and Rwanda ${ }^{1}$

\begin{tabular}{|c|c|c|c|c|c|}
\hline Median statistics & Peers & $\begin{array}{c}\text { Peers with } \\
\text { SDG } 3 \text { index }< \\
70\end{array}$ & $\begin{array}{l}\text { Peers with } \\
\text { SDG } 3 \text { index } \\
>=70\end{array}$ & $\begin{array}{c}\text { Rwanda } \\
- \\
2016 \\
\end{array}$ & $\begin{array}{c}\text { Rwanda } \\
- \\
2030 \\
\end{array}$ \\
\hline Number of countries & 57 & 49 & 8 & & \\
\hline GDP per capita (current USD) & 1,040 & 916 & 2,131 & 703 & 1,427 \\
\hline Doctors per 1000 population & 0.1 & 0.1 & 0.87 & 0.1 & 0.87 \\
\hline Other health staff per 1000 population & 1.5 & 1.3 & 3.58 & 2.8 & 3.58 \\
\hline Salary (GDP per capita ratio - absolute dollar number) & 18.2 & 22.8 & $7.4-15,764$ & 16.1 & $7.4-15,764$ \\
\hline Capital spending (\% of total health spending) & $3.7 \%$ & $3.9 \%$ & $0.7 \%$ & $3.5 \%$ & $0.7 \%$ \\
\hline Total health spending to GDP (\%) & $6.0 \%$ & $5.8 \%$ & $6.9 \%$ & $8.2 \%$ & $10.4 \%$ \\
\hline Spending per capita (current USD) & 59 & 57 & 148 & 58 & 148 \\
\hline Public Spending (\% of total health spending) & $52 \%$ & $50 \%$ & $49 \%$ & $66 \%$ & \\
\hline SDG3 score (0 to 100$)$ & 49 & 48 & 76 & 62 & \\
\hline
\end{tabular}

Source: IMF staff calculations on WHO and UN data.

Notes: Peers are countries with GDP per capita lower or equal to 3,000 USD per year. Blue numbers refer to cost values that are benchmarked.

${ }^{1}$ It should be noted that the 2016 private spending estimate of 2.8 percent of GDP is unanimously seen as too high by the authorities and all development partners, including local WHO representatives. Therefore, the comparison in Figure 3 focuses on public spending needs.

Figure 3. Health Public Spending Needs*_Comparison of Authorities and IMF Estimates (Current USD per capita and percent of GDP)

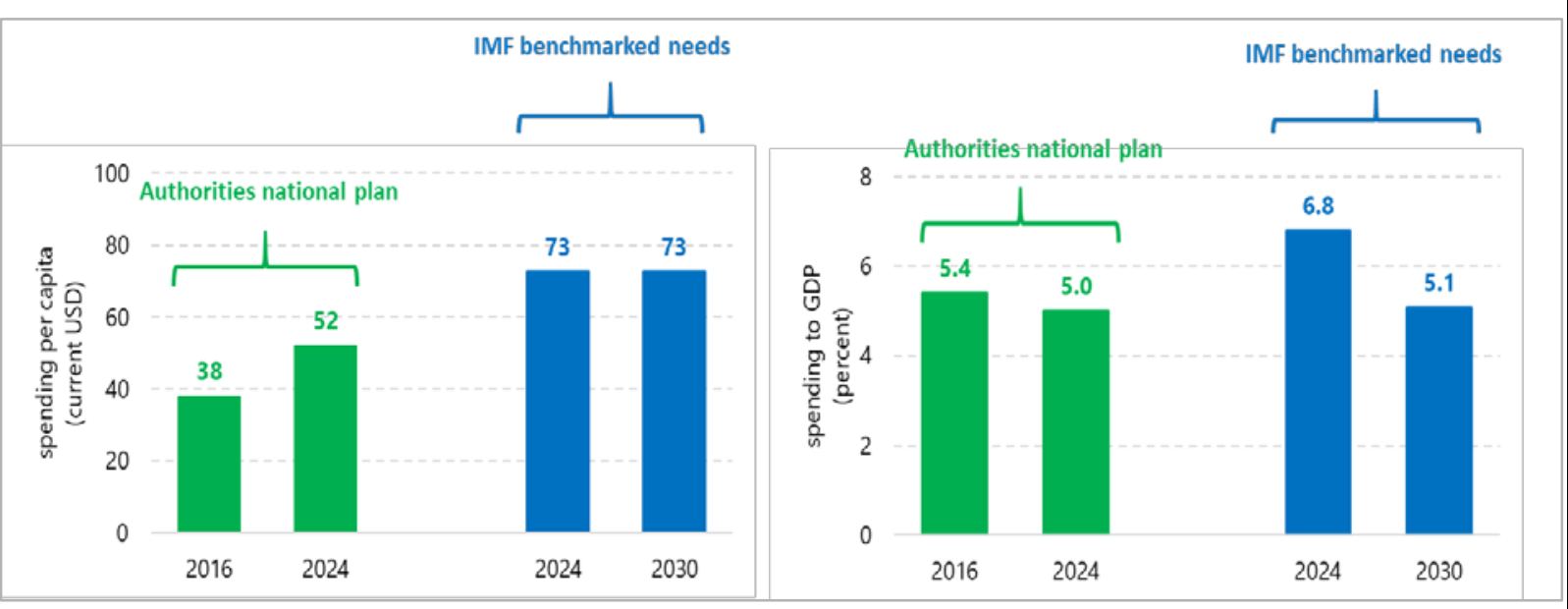

Source: IMF staff calculations on authorities' NST and WHO and UN data.

Notes: Blue bars are IMF estimates of what Rwanda would need to spend in order to achieve a high performance in health, either as early as in 2024, or in 2030. They show two point-estimates of spending needs and do not illustrate a spending path.

* IMF Estimates are given for the public health sector only. The 2030 public share of total health spending is benchmarked against the median value of 49 percent among peers with high performance (Table 2), deriving a per capita spending of US\$77. 


\section{Roads}

9. The rural access index for roads (RAI) is relatively low in Rwanda, due largely to the inadequate quality of existing roads (Table 3). Rwanda's RAI is 52 out 100, as only 5 percent of the current road network is paved and only 10 percent reaches all-season riding quality. Given its population density, most of Rwanda's investment will comprise upgrading and maintaining existing roads, especially in remote and high areas. A rough comparison with countries with GDP per capita lower than US $\$ 7,000$ per year, similar population density and a RAI greater than 75 , suggests that Rwanda would need to more than triple its density of high-quality roads through upgrading its existing network. Alternative regression analysis (considering the projected GDP per capita and population density for Rwanda in 2030) suggests that Rwanda's current road density would need to be increased by 1.6 to achieve a RAI higher than 75 , with annual investment needs of about 4 percent of GDP (Table 4).

Table 3. Median Reference Values for Road in Peer Countries and Rwanda

\begin{tabular}{|l|ccc|cc|}
\hline Median statistics & Peers & $\begin{array}{c}\text { Peers with } \\
\text { RAI < 75 }\end{array}$ & $\begin{array}{c}\text { Peers with } \\
\text { RAI > = 75 }\end{array}$ & $\begin{array}{c}\text { Rwanda } \\
-\end{array}$ & $\begin{array}{c}\text { Rwanda } \\
\mathbf{2 0 1 6}\end{array}$ \\
\hline Number of countries & 25 & 17 & 8 & & $\mathbf{2 0 3 0}$ \\
GDP per capita (current USD) & 1,900 & 1,444 & 3,261 & 703 & 1,427 \\
Road Density & 342 & 285 & 678 & 191 & $\mathbf{6 7 8}$ \\
Rural Access Index & 61 & 52 & 88 & 52 & - \\
\hline
\end{tabular}

Source: IMF staff calculations on World Bank and UN data.

Notes: Peers are countries with GDP per capita lower or equal to US $\$ 7,000$ per year. Blue numbers refer to cost values that are benchmarked. Estimates cover only new or upgraded-to-all-season roads.

\begin{tabular}{|l|c|}
\hline \multicolumn{2}{|c|}{ Table 4. Road Spending Needs in Rwanda-Regression Results } \\
\hline & \multicolumn{1}{|c|}{ Rwanda } \\
& - \\
& $\mathbf{2 0 3 0}$ \\
\hline & 4,068 \\
& Additional Km Needed \\
Total Cost (Million USD) & 4,436 \\
Cost per year (\% of GDP) & $3.9 \%$ \\
Source: IMF staff calculations on World Bank and UN data. Estimates include maintenance costs. \\
\hline
\end{tabular}

10. The NST sector strategy should, in theory, be sufficient to meet this gap. By 2030, the authorities plan to spend 5.8 percent of GDP per year to double the number of kilometers of district roads that meet the standard of "high riding quality". This exceeds the figure implied by regression analysis (Figure 4).

\section{Water}

11. Based on the World Bank WASH costing model, Rwanda would need to spend 4.5 percent of GDP per year to safely provide water to all households and provide fixed-point latrines to all (Table 6). This estimate is broadly in line with the authorities' own costing exercise 
(Figure 5). This result is based on current service coverage gaps, especially in rural areas (Table 5), and with a large share of spending accounted for by projections for a growing urban population with increased water consumption.

Figure 4. Road Spending Needs—Comparison of Authorities and IMF Estimates

(Kilometers and percent of GDP)

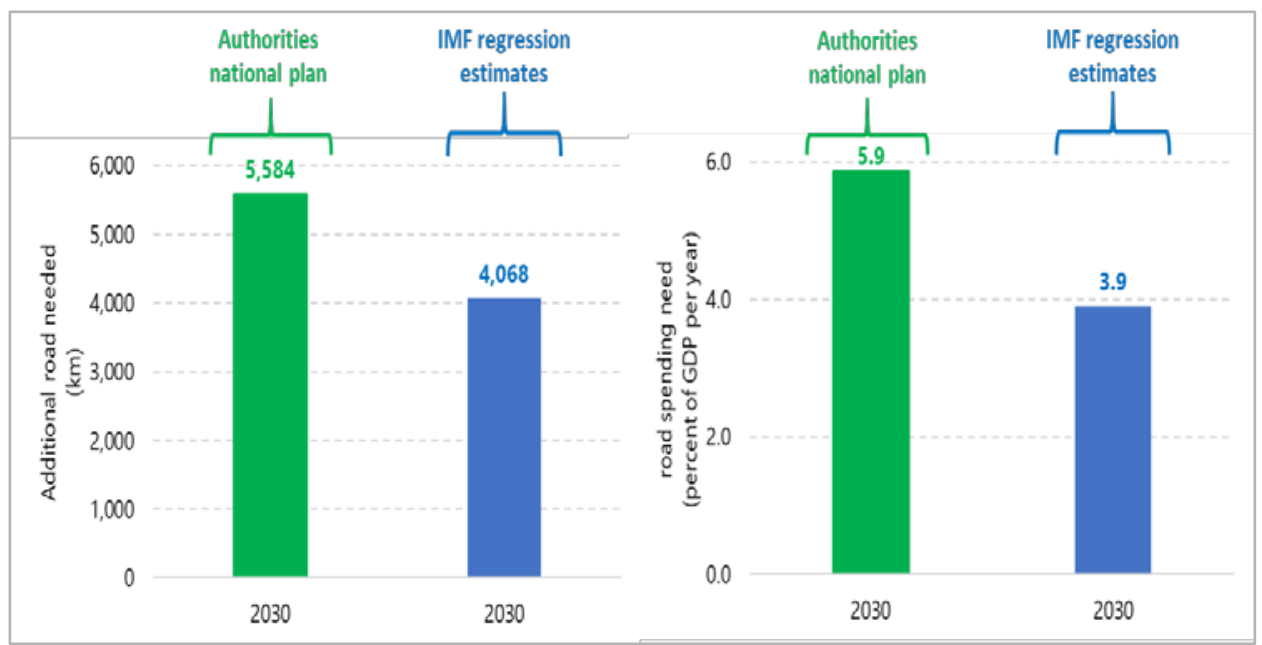

Source: IMF staff calculations on authorities' NST and World Bank CIA Factbook and UN data.

Table 5.2015 Coverage of WASH Services by Type of Areas

\begin{tabular}{|l|rr|}
\hline & \multicolumn{1}{|c|}{ Urban } & \multicolumn{1}{c|}{ Rural } \\
\hline $\begin{array}{l}\text { Basic water supply within } 30 \text { minutes } \\
\text { (no water quality) }\end{array}$ & $45 \%$ & $52 \%$ \\
Safely managed water supply at home & $12 \%$ & $0 \%$ \\
Improved sanitation (private only) & $61 \%$ & $64 \%$ \\
$\begin{array}{l}\text { Population with Any Fixed Point Latrines } \\
\text { Handwashing station, soap \& water at } \\
\text { home }\end{array}$ & & $98 \%$ \\
\hline
\end{tabular}

Source: World Bank Global WASH Cost Model.

Table 6. WASH Spending Needs Assessment for Rwanda-World Bank Model

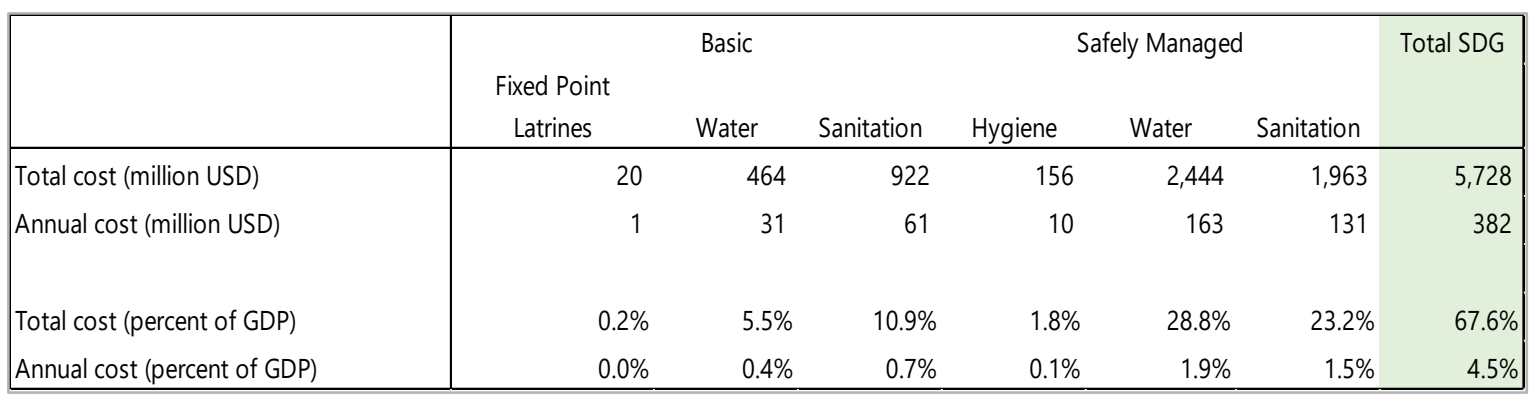

Source: IMF staff calculations on World Bank Global WASH Cost. 
Figure 5. Water and Sanitation Spending Needs-Comparison of Authorities and IMF Estimates

(Percent of GDP)

lathorities
Source: IMF staff calculations on World Bank Global WASH Cost and authorities' data.
Notes: The Government of Rwanda has asked the AfDB and the UNDP to develop a
costing tool of different Green Growth and Climate Resiliency medium-term investment
scenarios that involve building access to safely managed water to all households, an
objective in line with SDG 6. The estimate presented here refers to the "Medium Green"
scenario.

\section{Electricity}

12. Universal access to electricity would require an additional spending of $\mathbf{2}$ percent of GDP. Rwandan electricity sector is in a relatively unique situation of current excess capacity and low access to electricity (43 percent of households have electricity access). Assuming that 60 percent of all new connections will be on-grid while 40 percent will be off-grid and projecting that electricity, consumption will increase at the annual rate of 9 percent (reaching $730 \mathrm{kWh}$ in 2030 from an average of $238 \mathrm{kWh}$ in 2016), universal access cost is estimated at 2 percent of GDP.

\section{Summary of Spending Needs}

\section{Overall, estimated additional spending needs to achieve a higher SDG index by $\mathbf{2 0 3 0}$} for these selected sectors are substantial and reach about 20 percent of GDP. As a percent of GDP, an additional spending for education, health, roads, electricity and water and sanitation would total about 19.6 percent of GDP (Table 7). Infrastructure (roads, electricity and water and sanitation) is where SDG performance lags the most and seems to be where spending needs are the highest. Education follows closely behind with a spending need estimate reaching 7 percent of GDP. Beyond the levels, the composition of spending is also key to achieve high SDG performance. In Rwanda, investment priorities in education and roads appear broadly in line with what high achieving SDG achievement (i.e., hiring better trained teachers in primary level, or upgrading to high riding quality district roads connecting rural areas). In health, granular data on spending composition to guide the 
allocation of the required additional health spending is missing. Clearly, a costing of all sectors underlying the NST and SDGs would provide a larger estimate still of additional spending needs.

\begin{tabular}{|c|c|}
\hline \multicolumn{2}{|c|}{$\begin{array}{l}\text { Table 7. Estimated Spending Needs in Rwanda } \\
\text { (Additional percent of GDP in the year 2030) }\end{array}$} \\
\hline & Total \\
\hline Education & 7.0 \\
\hline Health & 2.2 \\
\hline Road & 3.9 \\
\hline Water & 4.5 \\
\hline Electricity & 2.0 \\
\hline Total & 19.6 \\
\hline
\end{tabular}




\section{Annex III. Risk Assessment Matrix ${ }^{1}$}

\begin{tabular}{|c|c|c|c|c|}
\hline Source of Risk & $\begin{array}{l}\text { Relative } \\
\text { Likelihood }\end{array}$ & $\begin{array}{c}\text { Time } \\
\text { Horizon }\end{array}$ & Expected Impact on Economy & Policy Response \\
\hline \multicolumn{5}{|c|}{ Domestic Risks } \\
\hline $\begin{array}{l}\text { Inadequate } \\
\text { external } \\
\text { financing and } \\
\text { private sector } \\
\text { growth to } \\
\text { finance NST. }\end{array}$ & High & MT, LT & $\begin{array}{l}\text { High. The risk is that of a missed } \\
\text { opportunity to raise growth, } \\
\text { structural transformation, and } \\
\text { living standards as envisaged in } \\
\text { Vision } 2050 \text {. In light of this, the } \\
\text { revised framework already } \\
\text { accounts for partial } \\
\text { implementation. }\end{array}$ & 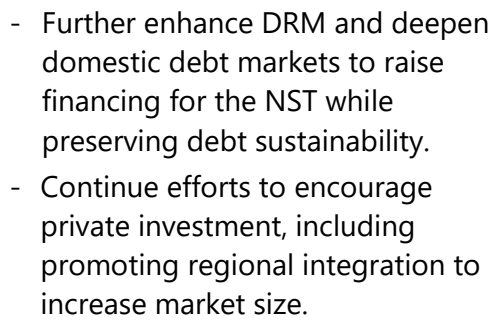 \\
\hline $\begin{array}{l}\text { Persistence of } \\
\text { variable } \\
\text { weather/pests. }\end{array}$ & High & $\begin{array}{l}\text { ST, MT, } \\
\text { LT }\end{array}$ & $\begin{array}{l}\text { Medium. Supply side shocks to } \\
\text { agriculture are the biggest risk to } \\
\text { growth and inflation. }\end{array}$ & $\begin{array}{l}\text { - Continue existing policies to } \\
\text { expand irrigation, improve } \\
\text { resilience, and increase } \\
\text { productivity. } \\
\text { - } \\
\text { Continue existing policies to } \\
\text { maintain food security stocks and } \\
\text { strong safety net. }\end{array}$ \\
\hline $\begin{array}{l}\text { Liabilities arise } \\
\text { from } \\
\text { unidentified } \\
\text { fiscal risks }\end{array}$ & Medium & $\begin{array}{l}\text { ST, MT, } \\
\text { LT }\end{array}$ & $\begin{array}{l}\text { Medium. Too big to fail private } \\
\text { investments and/or government } \\
\text { involvement in strategic growth } \\
\text { areas/PPPs could involve fiscal risks. }\end{array}$ & $\begin{array}{l}\text { - } \square \text { Implement recommendations of } \\
\text { Fiscal Transparency Evaluation } \\
\text { - } \square \text { Domestic fiscal risk assessment. }\end{array}$ \\
\hline \multicolumn{5}{|c|}{ External Risks } \\
\hline $\begin{array}{l}\text { Rising } \\
\text { protectionism } \\
\text { and retreat from } \\
\text { multilateralism. }\end{array}$ & High & ST, MT & $\begin{array}{l}\text { Low. Limited impact, but lower } \\
\text { external demand could reduce } \\
\text { exports. }\end{array}$ & $\begin{array}{l}\text { - } \square \text { Maintain exchange rate flexibility. } \\
\text { - } \square \text { Pursue efforts to promote } \\
\text { regional integration }\end{array}$ \\
\hline $\begin{array}{l}\text { Weaker-than- } \\
\text { expected global } \\
\text { growth: } \\
\bullet \square \quad \text { U.S. } \\
\bullet \quad \square \quad \text { Europe } \\
-\square \quad \text { China }\end{array}$ & $\begin{array}{l}\text { Medium } \\
\text { High } \\
\text { Medium }\end{array}$ & $\begin{array}{c}\text { ST, MT } \\
\text { ", }\end{array}$ & $\begin{array}{l}\text { Low. Weaker global growth could } \\
\text { adversely impact: (i) tourism and } \\
\text { exports; and (ii) ODA and FDI. }\end{array}$ & $\begin{array}{l}\text { - Maintain exchange rate flexibility. } \\
\text { - } \square \text { Diversify sources of external } \\
\text { financing and continue } \\
\text { diversifying exports. }\end{array}$ \\
\hline $\begin{array}{l}\text { Intensification of } \\
\text { security risks. }\end{array}$ & High & ST, MT & $\begin{array}{l}\text { Low. Regional political tensions } \\
\text { have thus far had little impact on } \\
\text { tourism or domestic security. }\end{array}$ & $\begin{array}{l}\text { - Maintain current policies (e.g. } \\
\text { financing UN peacekeeping ops, } \\
\text { food security stocks) }\end{array}$ \\
\hline $\begin{array}{l}\text { Large swings in } \\
\text { energy prices. }\end{array}$ & Medium & ST, MT & $\begin{array}{l}\text { Medium. Higher energy prices } \\
\text { would worsen the current account } \\
\text { deficit and increase inflation. }\end{array}$ & $\begin{array}{l}\text { - } \square \text { Maintain exchange rate flexibility. } \\
\text { - } \square \text { Continue investments to reduce } \\
\text { dependency on imported fuel. }\end{array}$ \\
\hline
\end{tabular}

\footnotetext{
${ }^{1}$ The Risk Assessment Matrix (RAM) shows events that could materially alter the baseline path (the scenario most likely to materialize in the view of IMF staff). The relative likelihood is the staff's subjective assessment of the risks surrounding the baseline ("low" is meant to indicate a probability below 10 percent, "medium" a probability between 10 and 30 percent, and "high" a probability between 30 and 50 percent). The RAM reflects staff views on the source of risks and overall level of concern as of the time of discussions with the authorities. Non-mutually exclusive risks may interact and materialize jointly. "Short term (ST)" and "medium term (MT)" and "long term (LT)" are meant to indicate that the risk could materialize within 1 year, 3 years, and 10 years respectively.
} 


\section{Annex IV. External Sector Assessment}

Based on various analytical metrics, the external position of Rwanda is assessed to be broadly consistent with fundamentals and desirable policy settings. Rwanda's external position has improved in recent years, supported by adjustment policies, including exchange rate depreciation. Analysis of optimal coverage indicates that international reserves are within the optimal range. Measures of nonprice competitiveness indicate a strong business environment.

\section{Context}

1. Following a sharp correction in 2017, Rwanda's current account deficit stayed at $\mathbf{7 . 9}$ percent of GDP in 2018. After a period of deterioration due to a range of structural and temporary factors, an improvement in Rwanda's trade deficit drove a sharp narrowing of the current account deficit in 2017. The improvement reflected the unwinding of some temporary factors-such as the completion of several large investment projects-as well as a recovery in commodity prices and structural improvements, supported by exchange rate adjustment and strategic government interventions supporting domestic production and export capacity. The current account deficit stayed at 7.9 percent of GDP in 2018, compared to 7.8 percent in 2017. This lower-than-expected deficit primarily related to delays in airport construction and more domestic production of construction materials. Import growth did pick up, however, reflecting higher fuel prices and other large construction projects and growth. Driven by robust export growth, improvements in the current account balance are expected to continue over the medium-term.

\section{Improvements in financial and current flows have} rebuilt reserve levels. Overall, having declined to $\$ 740$ million in mid-2015, international reserves increased to US $\$ 1,319$ million by end-2018. In terms of months of prospective import coverage, reserves are estimated to increase from 2.9 to 4.6 months during the same period. Over the medium term, the financial inflows are expected to increase, including to support NST implementation and respond to growing investment opportunities.

3. Rwanda's Real Effective Exchange Rate (REER) has depreciated slightly since the middle of 2018. Since the NEER has remained relatively stable, the depreciation of the
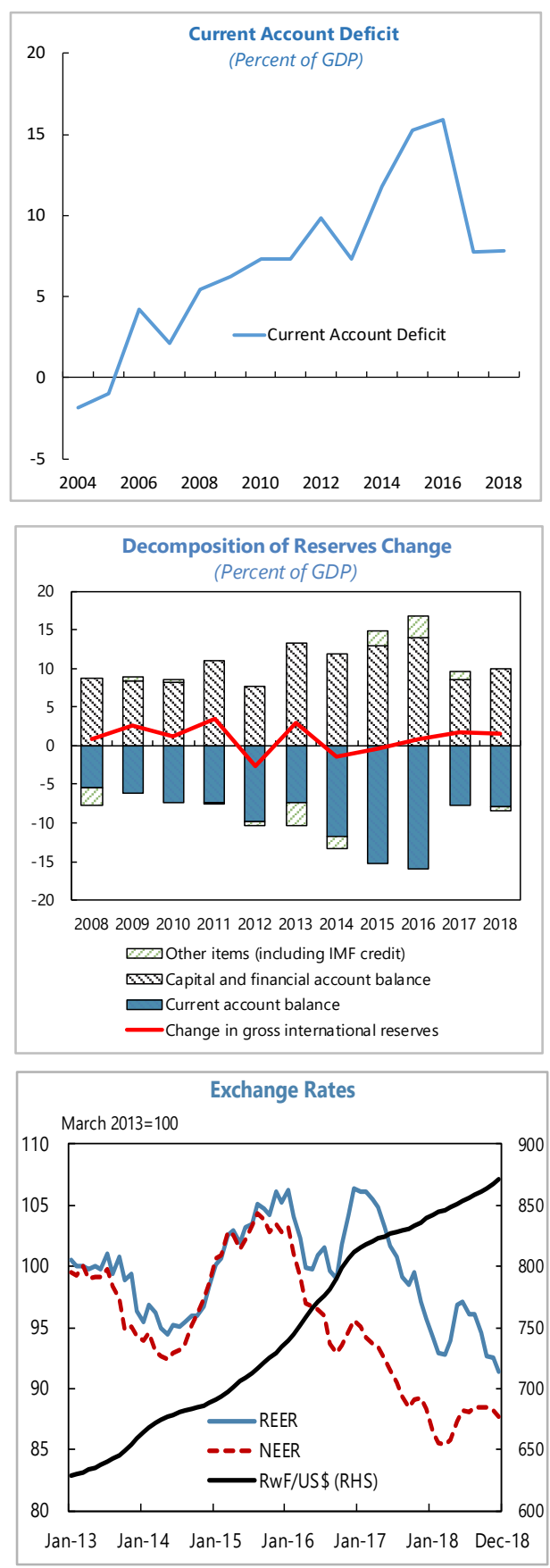
REER likely reflects muted domestic inflation in Rwanda.

\section{External Position Assessment}

\section{The assessment of the external position builds} on both the External Balance Assessment for developing and emerging economies (EBA-Lite) and complementary information. The EBA-Lite methodology for Rwanda includes two approaches: the current account (CA) model and the real effective exchange rate (REER) model. The approaches are based on panel regressions and provide estimated current account and exchange rate "norms" consistent with fundamentals and desired policy settings.

\section{Using the two separate models, staff assesses that the external position and the real effective exchange rate in $\mathbf{2 0 1 8}$ are broadly in line with the macroeconomic fundamentals.}

- $\square$ The CA model suggests that the current account deficit in 2018 was very close to its estimated norm. ${ }^{1}$ The model estimates a 2018 CA norm for the current account deficit of 8.2 percent of GDP (text chart). Comparing this to the current account deficit of 7.9 percent of GDP, the difference is 0.3 percentage points, within the range of 1.0 percentage points, implying that the REER is broadly consistent with fundamentals and desirable policy settings. The REER model also indicates that the RwF is broadly consistent with the country's macroeconomic fundamentals in 2018, with only a small gap of -1.7 percent, within the range of 5.0 percentage points (text chart). ${ }^{2}$
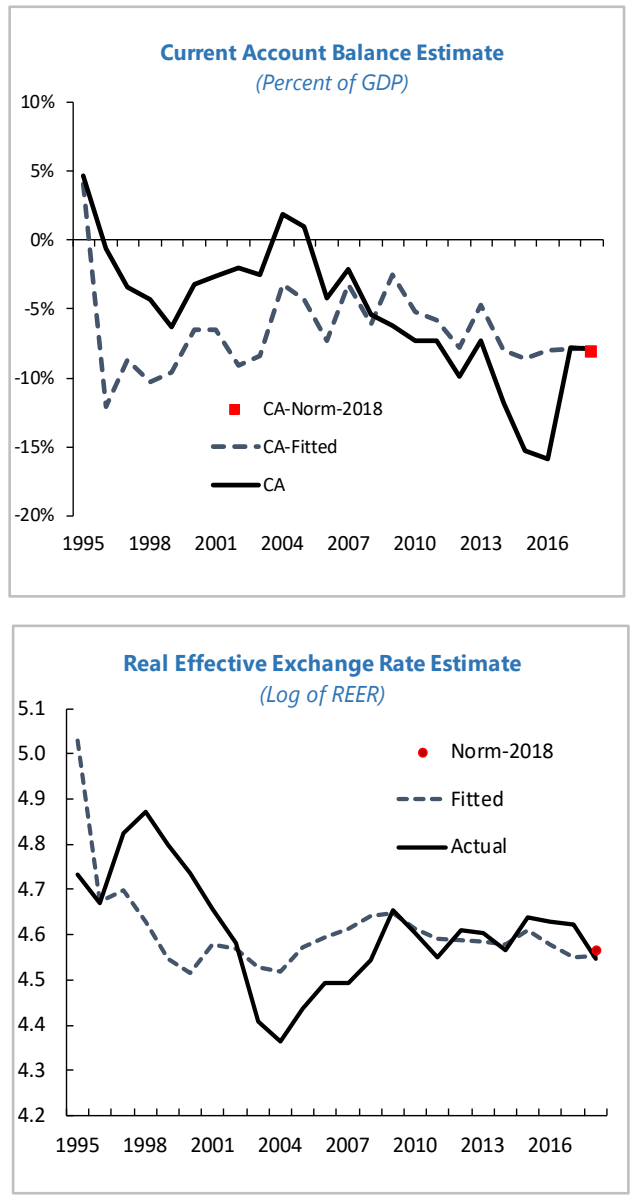

\begin{tabular}{|lcc|}
\hline \multicolumn{3}{|c|}{ Rwanda: EBA-Lite Results, 2018 } \\
\hline \multicolumn{1}{|c|}{ Approach } & Current Account Model & REER Model \\
\hline 2018 Current Account & $-7.9 \%$ & \\
Current Account Norm & $-8.2 \%$ & \\
Current Account Gap & $0.3 \%$ & \\
o/w Policy Gap & $0.1 \%$ & 4.55 \\
In(REER) Actual & & 4.56 \\
In(REER) Norm & & -0.01 \\
O/w Policy Gap & & $\mathbf{- 1 . 7 \%}$ \\
REER Gap & $\mathbf{- 1 . 4 \%}$ & \\
\hline Source: IMF staff estimates. & & \\
\hline
\end{tabular}

\footnotetext{
${ }^{1}$ The CA panel regression model compares Rwanda's current account balance with a level implied by the country's macroeconomic fundamentals adjusted for a policy gap-the current account norm. T The headline current account balance was used, in contrast to a "structural" current account balance which excluded imports with tied financing used in the 2017 Article IV, because the revised EBA-lite methodology in 2018 takes into account the role of aid in the model.

2 The REER model is a panel regression model that includes fundamental and policy variables that would affect the REER directly or indirectly through changes to the current account balance. The methodology is outlined in Methodological Note on EBA-Lite, February 2016.
} 


\section{Indicators of Competitiveness}

\section{Rwanda's ranking in the World Bank} "Doing Business" index has improved sharply in recent years. In the World Bank's 2019 Doing Business Report, Rwanda's overall rank for 2018-19 was 29 out of 190 economies and the second best for a Sub-Saharan African country after Mauritius. ${ }^{3}$ Rwanda's rank has moved up 27 places since 2017. Rwanda compares favorably on many sub-indicators relative to its peers. Access to electricity is being addressed in the National Strategy for Transformation.

\section{The World Economic Forum's 2018 Global Competitiveness Index (GCI) reinforces these findings. Based on $\mathrm{GCl}$,} Rwanda globally ranked $29^{\text {th }}$ out of 140 countries in terms of institutional quality, and $60^{\text {th }}$ in terms of business dynamism. The main area of weakness is labor skills, which in turn leads to a lower score on innovation capability. Market size continues to be an important constraint, and one that Rwanda is trying to alleviate through its activism on the Continental Free Trade Area.
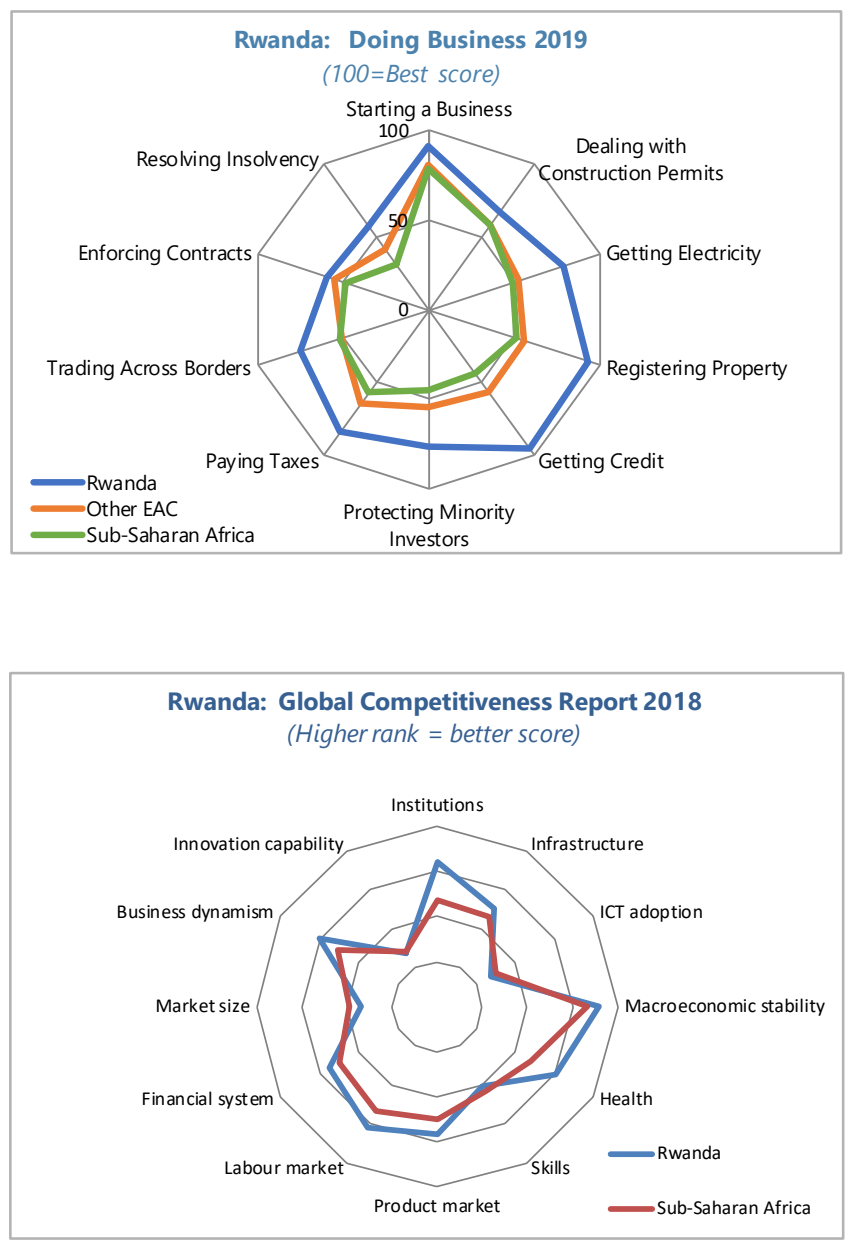

\section{Adequacy of International Reserves}

\section{At end-2018, international reserves are estimated to stand at $\mathbf{4 . 6}$ months of} prospective imports, which is within the optimal range. Historically, the IMF has recommended optimal reserve levels of 4-5 months of imports for Rwanda, and the central bank has sought to maintain reserves at a minimum of 4 months of prospective goods and services imports. Modelbased estimates indicate an optimal range of 3.5-4.5 months of imports. The range indicated by the Fund's approach to Assessing Reserve Adequacy in Credit Constrained Economies (ARA-CC) depends, among other factors, on the cost of holding reserves. ${ }^{4}$ In the case of Rwanda, the model's optimal range is substantially lowered by being classified as having a more flexible rather than fixed exchange rate regime (text chart). In this case, an optimal level of international reserves would be

\footnotetext{
${ }^{3}$ Since both the World Bank's Doing Business indicators and the World Economic Forum's Global Competitiveness index are partly based on survey data, there is some uncertainty around point estimates.

${ }^{4}$ For more details on the ARA-CC approach see IMF Policy Paper, 2014, "Assessing Reserve Adequacy-Specific Proposals."
} 
3.5-4.5 months of prospective imports, when an opportunity cost of holding reserves is in the range of 3-4 percent (proxied here by the real return on Rwanda's sovereign 10-year Eurobond). However, the model's results are uncertain because the ARA-CC approach may not fully capture all developments and risks affecting Rwanda, which remains vulnerable to external shocks such as mineral price declines given its narrow export base. In sum, staff would consider reserves in the range of 4.0-5.0 months optimal.

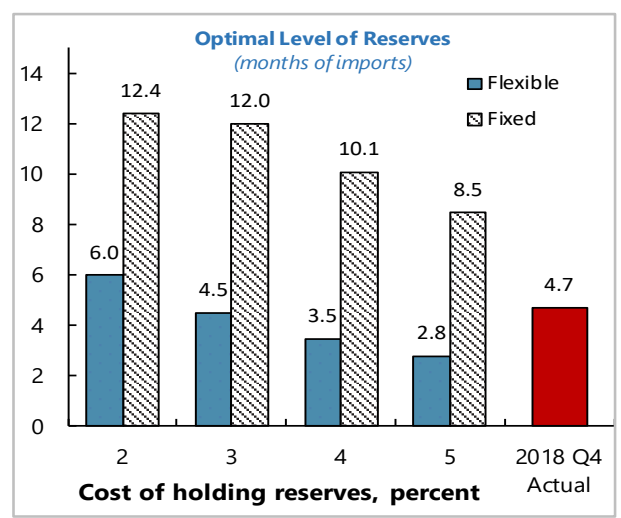




\section{Annex V. Capacity Development Strategy for FY2020}

Rwanda is a high intensity TA user, has relatively strong institutional capacity, and a good track record of implementing TA recommendations. Capacity Development efforts reflect the Fund's policy engagement with Rwanda, namely support for implementation of the country's National Strategy for Transformation, while also ensuring macro stability. TA focuses on the main areas of fiscal transparency, domestic revenue mobilization and implementation of the new forward-looking monetary policy framework. The authorities have requested a new financial stability reviewimportant in this respect would be additional focus on financial sector development.

\section{Key Overall CD Priorities Going Forward}

\begin{tabular}{|l|l|}
\hline \multicolumn{1}{|c|}{ Priorities } & \multicolumn{1}{c|}{ Objectives } \\
\hline Public Financial Management & $\begin{array}{l}\text { Improve fiscal transparency, including through moving to } \\
\text { GFS2014, and systematically identify and mitigate fiscal risks, with } \\
\text { help of Fiscal Transparency Evaluation. }\end{array}$ \\
\hline Tax Policy & $\begin{array}{l}\text { Develop a medium-term revenue strategy based on the recent } \\
\text { TADAT; VAT gap analysis; assessment of tax expenditures; and an } \\
\text { overall diagnostic of the policy and legislative framework. }\end{array}$ \\
\hline $\begin{array}{l}\text { Monetary and Macroprudential } \\
\text { policy }\end{array}$ & $\begin{array}{l}\text { Provide TA on FPAS and structural reforms to support the move to } \\
\text { an interest rate-based monetary framework. }\end{array}$ \\
\hline $\begin{array}{l}\text { Financial supervision and } \\
\text { regulation }\end{array}$ & $\begin{array}{l}\text { Conduct a financial stability assessment, but also with attention to } \\
\text { financial development objectives. }\end{array}$ \\
\hline
\end{tabular}




\section{Appendix I. Letter of Intent}

Kigali, June 11, 2019

Ms. Christine Lagarde

Managing Director

International Monetary Fund

Washington, D.C. 20431

U.S.A.

Dear Ms. Lagarde:

Our 2013-18 economic program, supported by a Policy Support Instrument (PSI), was instrumental in achieving high and inclusive growth. Domestic revenue mobilization, careful spending containment and strong debt management have rendered fiscal and debt positions sustainable, while still allowing for a growth-enhancing scaling up of public investment and social spending in line with our development strategy.

To continue to demonstrate our commitment to sound macroeconomic policies, the Government of Rwanda requests approval of a new macroeconomic and structural reform program supported by the Policy Coordination Instrument (PCI) for the period June 2019-June 2022. To support this request, this Program Statement (PS) outlines our objectives and sets out the economic policies that the Government and the National Bank of Rwanda (NBR) intend to implement under this new program.

The new program is intended to support implementation of the National Strategy for Transformation, while maintaining macroeconomic stability. With this aim, the program will seek to achieve: (1) a medium term fiscal path that allows for more spending to reach our National Strategy for Transformation (NST 1) goals while maintaining public debt at a sustainable level; (2) momentum in mobilizing domestic resources to support development goals, including through broadening the tax base and strengthening tax compliance; (3) enhanced fiscal transparency; and (4) seamless implementation of the National Bank of Rwanda's new forward-looking monetary policy operational framework, including through development of financial markets and broader access within the economy to financial resources.

The implementation of our program will be monitored through quantitative targets, including a monetary policy consultation clause, continuous targets, and reform targets, as described in the PS and the attached Technical Memorandum of Understanding (TMU). There will be six reviews of the arrangement by the Fund, schedules to be completed on a semi-annual basis to 
assess progress in implementing the program and reach understandings on any additional measures that may be needed to achieve its objectives.

We believe that the policies and measures set forth in this PS are appropriate for achieving the objectives of the $\mathrm{PCl}$-supported program. Given its commitment to macroeconomic stability, we will promptly take any additional measures that may become appropriate for this purpose. We will consult with the Fund on the adoption of these measures and in advance of revisions to the policies contained in this PS. Moreover, we will provide all information requested by the Fund to assess implementation of the program.

We wish to make this letter available to the public, along with the PS and TMU, as well as the IMF staff report on the request for a PCl and 2019 Article IV Consultation. We therefore authorize their publication and posting on the IMF website, subject to Executive Board approval. We will simultaneously publish these documents in Rwanda.

Sincerely,

/s/

Ndagijimana, Uzziel

Minister of Finance and Economic Planning /s/

Rwangombwa, John

Governor, National Bank of Rwanda

Attachments: I. Program Statement

II. Technical Memorandum of Understanding 


\section{Attachment I. Program Statement}

1. This program statement sets out our economic program for the next $\mathbf{3 6}$ months. The program aims to support implementation of the National Strategy for Transformation (NST 1), while maintaining macroeconomic stability. To this end, the program focuses on policies (1) to ensure a medium term fiscal path that allows for more spending to reach NST 1 goals while maintaining public debt at a sustainable level; (2) to regain momentum in mobilizing domestic resources to support development goals, including through broadening the tax base and strengthening tax compliance; (3) to achieve enhanced fiscal transparency; and (4) to seamlessly implement the National Bank of Rwanda's new forward-looking monetary policy operational framework.

\section{Rwanda has succeeded in addressing external imbalances and restoring high and} inclusive growth momentum. In spite of various shocks, supported by the five-year PSI completed in December 2018, we have made good progress toward the objectives of our program. Domestic revenue mobilization, careful spending containment and strong debt management have rendered fiscal and debt positions sustainable, while still allowing for a growth-enhancing scaling up of public investment and social spending in line with our development strategy. Monetary policy has kept inflation low while supporting macroeconomic stability and maintaining broad exchange rate stability. Numerous reforms have been introduced to establish the preconditions for a forwardlooking monetary policy framework, while inflation has remained contained and financial sector supervision and stability has been enhanced.

\section{However, further efforts in implementing the structural and institutional reform} agenda are needed to attain NST 1 objectives while maintaining macroeconomic stability. Our plans envisage measures to support higher value-added economic activity, diversified exports, and foster private sector-led growth, providing a sound foundation for sustaining high and inclusive growth as well as poverty reduction. We will continue to advance reforms in public financial management, fiscal transparency, tax policy, revenue administration, social transformation including education, transformational governance including service delivery. Such reforms will sustain domestic revenue mobilization efforts, more efficient and effective spending thus helping increase the fiscal space to address large unmet infrastructure needs. We will also implement multi-sector joint action plans to accelerate poverty reduction. These will be done through special interventions to support poorest households in relation to education, skills development, provision of basic infrastructure including access to electricity, increase in agricultural productivity.

\section{Recent Economic Developments and Outlook}

4. Strong economic performance continues. Growth has accelerated in 2018 (8.6 percent year-on-year) supported by services and industry sectors. The Services sector grew by 9 percent and was the biggest contributor to the overall growth. Trade and transport services performed particularly well with respectively 15 and 18 percent. The Industry sector grew by 10 percent thanks to construction and manufacturing, which grew respectively by 14 and 11 percent. 
5. Inflation remains low and relatively stable. Headline inflation remained below our target band since September 2018. The low headline and core inflation is mainly due to low food prices and base effects from 2017. While real interest rates remained high, real exchange depreciation provided favorable financial conditions.

\section{We expect consistent implementation of the policy actions and reforms envisaged} under the program to maintain macroeconomic stability, improving private sector dynamism, and fostering high and inclusive economic growth.

- $\square$ Real GDP growth is projected at average 8 percent in 2019-20 and remain at around 8 percent average over the medium term. Full implementation of our structural reform agenda will further boost growth potential.

- $\square$ Headline CPI inflation is projected to increase and gradually converge to the lower half of the medium-term inflation target band by 2019, remaining anchored at around 5 percent over the medium term.

- $\square$ The current account deficit is projected to rise to 9.6 percent in 2019 and decline thereafter, reflecting frontloaded public investment spending, consistent with meeting NST 1 targets. External financing will continue to rely on private direct investments and bilateral and multilateral infrastructure project loans.

\section{A. Fiscal Policies}

\section{Economic Policies}

7. We are committed to keep public debt-to-GDP ratio in present value (PV) terms below 50 percent, and maintain the risk of debt distress low, while supporting rapid and inclusive growth. Consistent with these objectives, our medium-term fiscal policies will continue to reflect the policies of fiscal consolidation and prudent borrowing to keep debt and external balances sustainable. Reflecting these policies, we will intensify our revenue mobilization efforts through ongoing and new tax policy measures as well as other administrative measures to increase domestic revenue collections for the financing of our NST1 priority investments. We expect our domestic revenue collections to increase on average by 0.2 percent of GDP over the medium term. Regarding expenditures, we will continue prioritization to contain recurrent spending so as to provide more resources for capital expenditure to implement our NST 1 priority projects. These policies will reduce our fiscal deficits over the medium term. Public debt in PV terms is projected to remain around [41] percent on average in the medium term. External debt profile will remain heavily in concessional terms while domestic debt maturity is expected to gradually increase in the medium term. During the 3-year program period, we will prioritize projects that will (1) increase access to electricity through construction of generating plants and investing in distribution systems; (2) increase access to sanitation and clean water through construction of treatment plants and rehabilitation of water facilities; (3) improve education through provision of adequate infrastructure facilities, essential supplies including books and required qualified teachers; (4) improve health services through provision of infrastructure facilities as well as equipment and other accessories including qualifies 
staff; and (5) accelerate facilitation of transport system through construction of new roads and the rehabilitation of existing ones.

\section{From FY2019/20 onwards, we will maintain the overall deficit on a 5-year rolling} average basis of no more than 5.5 percent of GDP. The 5 -year window would be based on performance in the last two fiscal years, and projections for the current and the next two fiscal years. This stance will imply that public debt-to-GDP ratio in PV terms will remain below 50 percent over the medium-to-long-term. It will also allow elevated levels of budgetary central government capital spending to address Rwanda's sizable infrastructure needs in line with NST 1 targets.

9. We will aim to further reduce fiscal risks and prepare contingency measures as needed. We will maintain an adequate level of fiscal buffers and will not accumulate public sector external debt payment arrears (continuous target). We will also refrain from accumulating domestic payment arrears (quantitative target).

\section{B. Structural Fiscal Policies}

10. We are committed to regaining momentum in mobilizing domestic resources to attain NST 1 goals.

- $\square$ Tax policy. Guided by the IMF technical assistance, we started to refine our tax expenditure analysis, we plan to further improve the methodology and regularly report on tax expenditure, seeking areas for streamlining exemptions (reform target). We will also take steps to improve tax compliance especially for VAT by introducing measures to encourage consumers to request invoices (reform target).

- $\square$ Tax administration. Based on the outcomes of the recent Tax Administration Diagnostic Assessment Tool Review in May 2019, we will take measures to strengthen tax compliance including:

$\circ \square$ Using the e-tax system to enhance audit case selection (reform target); reducing cash transactions and improving RRA access to electronic transactions; pre-populating tax returns.

$\circ \square$ Work to identify and recruit unregistered taxpayers and to continue improving the reliability of the registration database; and to cleanse the taxpayer ledgers.

$\circ \square$ Automating the risk-based verification process for refund claims to reduce the average processing-time for VAT refunds.

$\circ \square$ Redesign the Compliance Improvement Plan (CIP) tool to focus on the four compliance obligations (registration, filing, accurate reporting and payment).

$\circ \square$ Constantly evaluate the effectiveness of compliance mitigation strategies.

- $\square$ We will continue implementing measures to increase fiscal transparency.

$\circ \square$ Starting in FY19/20, we will begin producing annual and quarterly budget execution reports also in GFSM-2014 format (reform target). For FY19/20, we will continue also 
producing GFSM-86 format fiscal tables. Starting in FY20/21 we will only use GFSM-14 tables and terminology in our annual and quarterly budget execution reports.

$\circ \square$ We are committed to expand the coverage of fiscal reporting from budgetary central government to central government by including extra budgetary entities (reform target).

$\circ \square$ Guided by the Fiscal Transparency Evaluation the country is undertaking, we will come up with a sequenced fiscal transparency actions plan addressing priorities to further fiscal transparency. On the fiscal risks particularly, we have requested a technical assistance from IMF East AFRITAC to build capacity within the Ministry of Finance and Economic Planning in assessing different risks to fiscal position and the fiscal outlook.

11. We are committed to improve resource efficiency, fiscal transparency and strengthen management and sustainability of all schemes managed by RSSB. We have plans to procure an IT system to capture all RSSB processes, contract a diagnostic study on optimal RSSB asset allocation and produce financial and management reports from the IT system for all schemes managed by RSSB (reform targets).

\section{Monetary and Exchange Rate Policies}

12. Our new forward-looking monetary policy operational framework remains appropriate for maintaining stable inflation and protecting the economy against external shocks. We remain committed to the objective of keeping inflation within the target band ( $5 \pm 3$ percent). Inflation developments will be monitored via a monetary policy consultation clause with consultation bands with the staff corresponding to our target band and consultation bands with the IMF's Executive Board will be temporarily wider by 1 percentage points ( $5 \pm 4$ percent, Table 1 a). In this context we implemented 50 basis points key policy rate cut on May 6, on the back of subdued headline and core inflation, reduction in medium-term inflation outlook, and continued lack of exchange rate pressures.

13. We are taking further steps to support our new monetary policy framework, including enhanced communication. We will publish macro projections for MPC decision making in quarterly inflation reports starting in May-June 2020 (reform target). We are committed to clarify to the public the new monetary policy framework through outreach events involving including academia, thinktank and media.

14. We will continue to deepen financial markets, to further strengthen monetary policy transmission mechanism. We are taking steps to implement true repo which will contribute to the development of interbank market. This new framework consists of enhancing the existing interbank market whereby banks will be able to engage in safe and collateralized borrowing and lending activities with each other. Unlike the current forms of pledging securities, lending bank will be able to take full ownership of the collateral until the loan maturity. This will reduce both the risk as well as the cost of engaging in short term transactions. 
15. We will maintain a market driven exchange rate regime and make necessary adjustments depending on external conditions, in line with our monetary policy framework. We believe that exchange rate is the first line of defense against external shocks. Given the significant official development assistance flows and relatively low private portfolio flows and shallow foreign exchange markets, we will continue supplying foreign exchange to the market to satisfy foreign exchange demand, reflecting mostly execution of infrastructure capital projects, while considering the implications for financial sector and price stability. The current level of gross international reserves at 4.5 months of prospective imports is comfortable for precautionary purposes.

\section{Financial Sector Policies}

\section{We will continue to strengthen financial sector regulatory and supervisory} frameworks, to fully align with international standards, while safeguarding private sector contribution to achieving NST 1 targets. Basel II/III-compliant regulatory standards on capital, liquidity, and risk management, as well as updated standards on disclosure and regulatory reporting have been implemented. Full implementation of IFRS 9 started on January 1, 2018. On the other hand, we issued a guidance on treatment of domestic treasury bills and government bonds, among others - to limit excessive increase in provisions and clarify on areas that the industry had challenge to implement. At the same time to mitigate adverse impact on private sector credit availability, we allowed commercial banks to spread IFRS-9-related excess impairment equally over 4 years for the purpose of calculating core capital.

17. We are strengthening the AML/CFT framework. Guided by the IMF technical assistance, we developed several offsite and onsite AML/CFT supervisory tools, namely on-site inspection procedures, and tools to collect data on institutions' inherent money laundering/terrorist financing (ML/TF) risks and their risk management practices in 2015. We enacted a new AML/CFT law in August 2018. We are in the process of identifying required modification to the tools developed in 2015.

18. We will work on strategies for capital market deepening and development finance. Greater access to capital markets should make it possible for some companies, including those focused on agriculture, to reduce their reliance on short-term bank finance and increase access to longer-term risk capital, with consequent benefits to growth and employment. A successful PublicPrivate Partnership (PPP) approach to infrastructure investment similarly requires access to capital market finance. Domestic savings institutions need to be able to supply such capital and, in so doing, offer those citizens who invest in them a better choice of savings products to meet their needs. To ease access to long-term funding through the capital market by the economy, the Government of Rwanda has put in place a 10-year development strategy "Capital Market Master Plan, CMMP" to develop and deepen the capital market industry during the period 2018-28. This Master Plan sets out the steps which the Government intends to undertake in order to be able to exploit the tools of capital market finance to unleash the full potential of the economy and to enable Rwanda to play its role as a financial hub within the economy of East Africa. The objective of the 
Capital Market Master Plan is to make capital markets work for Rwanda. The Plan sets out steps to be taken to develop a pipeline of firms which will access the different forms of capital market finance at different stages in their development. To achieve this requires multiple actions to improve corporate financial reporting, business planning and corporate governance, based on education and training for business leaders. In parallel, policy actions are envisaged to also develop the capacity of domestic institutional investors to invest in a wider range of capital market products and to mobilize small savers to invest, with sufficient education and appropriate protections, in capital market products in innovative ways.

\section{E. Structural Policies}

19. Consistent with NST 1, we will continue to implement a comprehensive set of regulatory reforms to improve the business environment to support higher private sector-led growth. Our primary focus is on achieving NST 1 goals also through policies that improve the business environment and private investment climate and promote job creation.

\section{We are implementing measures to diversify exports, increase productivity of} agriculture sector, improve educational attainment, and enhance urbanization. Guided by the recent study by the World Bank and the Government of Rwanda, "Drivers of Growth in Rwanda" we will dedicate external financing mobilized to achieve tremendous improvements in those areas mentioned above in order to orient the economy towards higher value-added activities and more production of tradable.

21. We are working to improve the quality and transparency of our national statistics. In September 2017, we subscribed to the IMF's eGDDS. Our overarching goal is to subscribe to the Special Data Dissemination Standards (SDDS) by June 2021and join Mauritius, Senegal, Seychelles, and South Africa from sub-Saharan Africa. To this end, NBR is taking steps to disseminate quarterly balance of payments and international investment position (IIP) by December 2019. Our current data dissemination fulfills the requirements of periodicity and timeliness for these two datasets. To further strengthen the collection of quarterly data, we launched a quarterly data collection from major entities using the Foreign Private Capital Survey questionnaire, starting from the first quarter of 2018. With guidance from the IMF TA, we are also taking steps to prepare the Data Template of International Reserves and Foreign Currency Liquidity (DTIRFCL), a prerequisite for subscription to the SDDS, by December 2019. NISR is taking steps to disseminate quarterly/monthly labor force statistics, monthly industrial production index, and monthly producer price index by June 2021.

\section{Program Monitoring}

22. Progress in the implementation of the policies under this program will be monitored through quantitative targets (QTs), including an inflation consultation clause, continuous targets (CTs) and reform targets (RTs). These are detailed in Tables 1a-b and 2, with definitions provided in the attached Technical Memorandum of Understanding. 


\begin{tabular}{|c|c|c|c|}
\hline \multicolumn{4}{|c|}{ Table 1a. Rwanda: Quantitative Targets 1/ } \\
\hline & end-Jun 2019 & end-Dec 2019 & end-Jun 2020 \\
\hline & Program & Program & Program \\
\hline \multicolumn{4}{|c|}{ (Billions of Rwandan francs, unless otherwise indicated) } \\
\hline \multicolumn{4}{|l|}{ Half-yearly Quantitative Targets ${ }^{1}$} \\
\hline 1. Ceiling on the overall deficit, including grants ${ }^{2}$ & 477 & 276 & 589 \\
\hline 2. Floor on stock of Net Foreign Assets & 850 & 980 & 858 \\
\hline 3. Ceiling on flow of net accumulation of domestic arrears & 0 & 0 & 0 \\
\hline \multicolumn{4}{|l|}{ Continuous Targets } \\
\hline 4. Ceiling on stock of external payment arrears (US\$ millions) ${ }^{3}$ & 0 & 0 & 0 \\
\hline \multicolumn{4}{|l|}{ Monetary Policy Consultation Band ${ }^{1,4}$} \\
\hline CPI Inflation target & 5.0 & 5.0 & 5.0 \\
\hline Inflation, upper inner-bound, percent & 8.0 & 8.0 & 8.0 \\
\hline Inflation, lower inner-bound, percent & 2.0 & 2.0 & 2.0 \\
\hline Inflation, upper bound, percent & 9.0 & 9.0 & 9.0 \\
\hline Inflation, lower bound, percent & 1.0 & 1.0 & 1.0 \\
\hline \multicolumn{4}{|l|}{ Memorandum items: } \\
\hline Total priority spending ${ }^{2}$ & 812 & 411 & 885 \\
\hline Flow of domestic revenue collection ${ }^{2,}$ & 1584 & 823 & 1726 \\
\hline \multicolumn{3}{|l|}{ public enterprises (US\$ millions) ${ }^{3}$} & 700 \\
\hline Total budget support (US\$ millions) ${ }^{2}$ & 664 & 439 & 617 \\
\hline Budget support qrants (US\$ millions) & 365 & 196 & 293 \\
\hline Budget support loans (US\$ millions) & 299 & 243 & 324 \\
\hline RWF/US\$ program exchange rate & 879.1 & 879.1 & 879.1 \\
\hline \multicolumn{4}{|l|}{ Sources: Rwandan authorities and IMF staff estimates and projections. } \\
\hline $\begin{array}{l}{ }^{1} \text { All items including adjusters are defined in the Technical Memorandum of Un } \\
{ }^{2} \text { Numbers for June } 2019 \text { are cummulative from 6/30/2018. Numbers for Decer } \\
{ }^{3} \text { Continuous targets. } \\
{ }^{4} \text { When the end-of period year-on-year average inflation is above/below the o } \\
\text { the Executive Board would be triggered. }\end{array}$ & r bound, a formal c & $\begin{array}{l}\text { /2019. } \\
\text { ultation with }\end{array}$ & \\
\hline
\end{tabular}




\section{Table 1b. Rwanda: Standard Continuous Targets}

Not to impose or intensify restrictions on the making of payments and transfers for current international transactions.

Not to introduce or modify multiple currency practices.

Not to conclude bilateral payments agreements which are inconsistent with Article VIII.

Not to impose or intensify import restrictions for balance of payments reasons. 


\begin{tabular}{|c|c|c|}
\hline \multicolumn{3}{|c|}{ Table 2. Rwanda: Reform Targets } \\
\hline Actions & Target Date & Objective \\
\hline $\begin{array}{l}\text { Produce annual tax expenditure report with updated methodology, and a description of broad } \\
\text { categories of beneficiaries. }\end{array}$ & end-Jun 2019 & Improve DRM \\
\hline Procure an IT system that will capture all RSSB processes & end-Jun 2019 & Improve resource efficiency \\
\hline Automating the risk based verification process for refund claims & end-Dec 2019 & Improve DRM \\
\hline Begin producing quarterly budget execution reports in GFS 2014 format. & end-Dec 2019 & Improve fiscal transparency \\
\hline Produce a comprehensive fiscal risk analysis report. & end-Jun 2020 & Mitigate fiscal risks \\
\hline Contract a diagnostic study on optimal RSSB asset allocation. & end-Jun 2020 & Improve resource efficiency \\
\hline $\begin{array}{l}\text { Expand coverage in fiscal reporting in GFS } 2014 \text { from budgetary central govt to central govt (i.e. } \\
\text { including extrabudgetary entities) }\end{array}$ & end-Dec 2020 & Improve fiscal transparency/PFM \\
\hline Produce financial and management reports from the IT system for all schemes managed by RSSB & end-Dec 2020 & $\begin{array}{l}\text { Improve fiscal tranparency and strengthen } \\
\text { management and sustainability of all schemes } \\
\text { managed by RSSB }\end{array}$ \\
\hline \multicolumn{3}{|l|}{ Monetary and Financial } \\
\hline $\begin{array}{l}\text { Improve communication for monetary policy by organizing quarterly outreach after each MPC meeting, } \\
\text { including roundtable discussions with CEOs of commercial banks and other financial institutions, as well } \\
\text { as other interested stakeholders. }\end{array}$ & end-Dec 2019 & Support new monetary policy framework \\
\hline $\begin{array}{l}\text { Publish macro projections for MPC decision making in quarterly inflation reports, according to best } \\
\text { practices established by other central banks. }\end{array}$ & end-Jun 2020 & Support new monetary policy framework \\
\hline Introduce a platform for issuing government securities using mobile phones & end-Jun 2020 & Deepen financial markets \\
\hline $\begin{array}{l}\text { Produce a study on consumer payment behavor analyzing micro-level data on consumer payment } \\
\text { choices }\end{array}$ & end-Dec 2020 & Deepen financial markets \\
\hline $\begin{array}{l}\text { Expand industrial and market expectation surveys that feed into macro forecasting, begin collecting } \\
\text { data to construct a purchasing manager's index, and accelerate publication of foreign private capital } \\
\text { survey }\end{array}$ & end-Dec 2020 & Support new monetary policy framework \\
\hline $\begin{array}{l}\text { Update the regulatory framework on true repo to rollout Global Master Repurchase Agreement } \\
\text { (GMRA) }\end{array}$ & end-Jun 2021 & Support new monetary policy framework \\
\hline
\end{tabular}




\section{Attachment II. Technical Memorandum of Understanding}

Kigali, Rwanda, June 11, 2019

\section{This memorandum defines the quantitative targets described in the program} statement (PS) for the period July 1, 2018 - June 30, 2020 supported by the IMF Policy Coordination Instrument (PCI), and sets out the data reporting requirements.

2. Program exchange rates. For accounting purposes, the program exchange rates in Text Table 1 will apply.

\begin{tabular}{|l|l|}
\hline \multicolumn{2}{|c|}{$\begin{array}{l}\text { Text Table 1. Program Exchange Rates from December 31, 2018 } \\
\text { (US\$ per currency unit, unless indicated otherwise) }\end{array}$} \\
\hline Rwanda Franc (per US\$) & 879.1 \\
\hline Euro & $1,004.9$ \\
\hline British Pound & $1,115.4$ \\
\hline Japanese Yen (per US\$) & 110.4 \\
\hline SDR & $1,222.6$ \\
\hline
\end{tabular}

\section{A. Quantitative Program Targets}

\section{Ceiling on Overall Fiscal Deficit Including Grants}

\section{A ceiling applies to the overall fiscal deficit of the budgetary central government} including grants. The ceiling for June 30, 2019 is cumulatively measured from June 30, 2018. The ceilings for December 31, 2019 and June 30, 2020 are cumulatively measured from June 30, 2019.

4. Definition. For the program, the overall fiscal deficit including grants is valued on a commitment basis. That is, the overall fiscal balance is defined according to the GFSM 2014 as net lending/net borrowing after transactions in assets and liabilities are adjusted for transactions deemed to be for public policy purposes (policy lending). Budgetary Central government expenditure (i.e. expenses plus net acquisition of non-financial assets) is defined on the basis of payment orders accepted by the Treasury, as well as those executed with external resources. This quantitative target is set as a ceiling on the overall fiscal deficit as of the beginning of the year.

\section{Adjusters to the Overall Fiscal Deficit Including Grants:}

- The ceiling on the overall deficit will be adjusted upward by the amount of any shortfall between actual and programmed budgetary grants (as defined in Table 1a of the PS), up to a maximum of RWF 87 billion.

- The ceiling on the overall deficit will be adjusted upward, up to a maximum of RWF87 billion, representing the amount of foreign financed net acquisition of non-financial assets (foreign financed capital expenditure) financed with drawdown of accumulated government deposits. 
- The ceiling on the overall deficit will be adjusted upward by the amount of unexpected public expenditures (expenses, and/or net acquisition of non-financial assets) on food imports in the case of a food emergency.

- The ceiling on the overall deficit will be adjusted upward (downward), up to a maximum of RWF87 billion, by any unplanned financing shortfall (surplus) from Peace Keeping Operations.

\section{Floor on Net Foreign Assets of the National Bank of Rwanda}

5. A floor applies to the net foreign assets (NFA) [could we reconsider using NIR since it eliminates exchange rate effects] of the NBR for June 30, 2019, December 31, 2019 and June 30, 2020.

6. Definition. NFA of the NBR in Rwandan francs is defined, consistent with the definition of the Special Data Dissemination Standard (SDDS) template, as external assets readily available to, or controlled by, the NBR net of its external liabilities. Pledged or otherwise encumbered reserve assets (including swaps) are excluded; such assets include, but are not limited to, reserve assets used as collateral or guarantee for third party external liabilities. Reserves assets corresponding to undisbursed project accounts are also considered encumbered assets and are excluded from the measurement of NFA for program purposes. Foreign assets and foreign liabilities in U.S. dollars are converted to Rwandan francs by using the U.S. dollar/Rwanda franc program exchange rate. Foreign assets and liabilities in other currencies are converted to U.S. dollars by using the actual end-ofperiod U.S. dollar/currency exchange rate. Foreign liabilities include, inter alia, use of IMF resources.

\section{Adjusters:}

- The floor on NFA will be adjusted downward by the amount of any shortfall between actual and programmed budgetary loans and grants per Table 1 of the PS, capped at RWF 87 billion.

- The floor on NFA will be adjusted downward (upward) by the surplus (shortfall) of cash external debt service payments compared to originally-scheduled payments.

- The floor on NFA will be adjusted downward by the amount of unexpected public expenditures on food imports in the case of a food emergency.

\section{Ceiling on the Stock of External Payment Arrears}

7. A continuous ceiling applies to the non-accumulation of payment arrears on external debt contracted or guaranteed by the budgetary central government and entities that form part of the budgetary process.

8. Definition. External payment arrears are defined as the amount of overdue external debt service obligations (principal and interest) arising in respect of obligations incurred directly or guaranteed by the budgetary central government and entities that form part of the budgetary process. A payment is overdue when it has not been paid in accordance with the contractual date 
(taking into account any contractual grace periods). Arrears resulting from the nonpayment of debt service for which a clearance framework has been agreed or a rescheduling agreement is sought are excluded from this definition.

\section{Ceiling on Net Accumulation of Domestic Expenditure Arrears of the Budgetary Central Government}

9. A ceiling applies to net accumulation of domestic expenditure arrears of the budgetary central government. ${ }^{1}$ The ceilings for June 30, 2019 is cumulatively measured from June 30, 2018. The ceilings for December 31, 2019 and June 30, 2020 are cumulatively measured from June 30, 2019.

10. Definition. Domestic expenditure arrears are defined as unpaid claims that are overdue by more than 90 days. Accumulation of domestic expenditure arrears of more than 90 days is calculated as a cumulative change in the stock of expenditure arrears of more than 90 days at each test date from the stock at the end of the previous fiscal year (June 30). Arrears related to claims preceding 1994 will not be counted in the calculation.

\section{B. Monetary Policy Consultation Clause (MPCC)}

11. Definition. MPCC headline inflation is defined as the year-on-year rate of change of monthly Consumer Price Index (CPI), averaged for the past 12-months, as measured by National Institute of Statistics Rwanda (NISR).

- If the observed headline inflation falls outside the \pm 3 percentage point range around the mid-point of target band value for end-June 2019, end-December 2019, and end-June 2020 test dates, the authorities will conduct discussions with the Fund staff.

- If the observed headline inflation falls outside the \pm 4 percentage point range around 5 percent for end-June and end-December 2019, and end-June 2020 test dates as specified in Table $1 \mathrm{a}$ in the PS, the authorities will complete a consultation with the Executive Board which would focus on: (i) the stance of monetary policy and whether the Fund-supported program remains on track; (ii) the reasons for program deviation, taking into account compensating factors; and (iii) proposed remedial actions if deemed necessary.

\section{Memorandum Items and Data Reporting Requirements}

12. For the purposes of program monitoring, the Government of Rwanda will provide the data listed below and in Table 1. Unless specified otherwise, weekly data will be provided within seven days of the end of each week; monthly data within five weeks of the end of each month; quarterly data within eight weeks.

\footnotetext{
${ }^{1}$ A negative target thus represents a floor on net repayment.
} 
13. Data on priority expenditure will be transmitted on a quarterly basis. Priority expenditure is defined as the sum of those recurrent expenditures, domestically-financed capital expenditures, and policy lending that the government has identified as priority in line with the NTS. Priority expenditure is monitored through the Integrated Financial Management System (IFMS) which tracks priority spending of the annual budget at the program level of the end of each quarter.

14. Detailed data on domestic revenues will be transmitted on a monthly basis. The domestic revenue is defined as total revenue (tax and non-tax revenues), per the budgetary central government statement of operations table, but including: (a) local government taxes (comprised of business licenses, property tax, and rental income tax); and (b) local government fees; and excluding and receipts from Peace Keeping Operations.

\section{Data on the contracting and guaranteeing by nonfinancial public enterprises of new} external borrowing with non-residents will be transmitted on test dates. The data excludes external borrowing by two state-owned banks, the Bank of Kigali and Rwanda Development Bank (BRD), which are assumed not to seek or be granted a government guarantee. The data also applies to private debt for which official guarantees have been extended, including future swaps involving foreign currency loans guaranteed by the public sector, and which, therefore, constitute a contingent liability of the public sector. The data will exclude external borrowing which is for the sole purpose of refinancing existing public-sector debt and which helps to improve the profile of public sector debt. The data will also exclude on-lending agreement between Government of Rwanda and public-sector enterprises.

16. The authorities will inform the IMF staff in writing prior to making any changes in economic and financial policies that could affect the outcome of the financial program. Such policies include, but are not limited to, customs and tax laws, wage policy, and financial support to public and private enterprises. The authorities will inform the IMF staff of changes affecting respect of continuous QTs. The authorities will furnish a description of program performance according to QTs as well as reform targets within 8 weeks of a test date. The authorities engage to submit information to IMF staff with the frequency and submission time lag indicated in TMU Table 1. The information should be mailed electronically to the Fund. (email to the ResRep and the mission chief). 
TMU Table 1. Summary of Reporting Requirements

\begin{tabular}{|c|c|c|c|}
\hline & $\begin{array}{l}\text { Frequency } \\
\text { of Data }\end{array}$ & $\begin{array}{l}\text { Frequency of } \\
\text { Reporting }^{8}\end{array}$ & $\begin{array}{l}\text { Frequency of } \\
\text { Publication }^{8}\end{array}$ \\
\hline Exchange Rates $^{1}$ & $\mathrm{D}$ & W & $\mathrm{D}$ \\
\hline $\begin{array}{l}\text { International Reserve Assets and Reserve Liabilities of the Monetary } \\
\text { Authorities }^{2}\end{array}$ & W & W & M \\
\hline Reserve/Base Money & W & W & M \\
\hline Broad Money & M & M & M \\
\hline Central Bank Balance Sheet & W & W & M \\
\hline Consolidated Balance Sheet of the Banking System & M & M & M \\
\hline Interest Rates ${ }^{3}$ & M & M & M \\
\hline $\begin{array}{l}\text { Volume of transactions in the interbank money market, repo operations, } \\
\text { and foreign exchange markets, sales of foreign currencies by NBR to } \\
\text { commercial banks and other foreign currency interventions by NBR. }\end{array}$ & $\mathrm{D}$ & W & W \\
\hline $\begin{array}{l}\text { Composite Index of Economic Activity (CIEA) and sub-components } \\
\text { compiled by the NBR }\end{array}$ & M & M & M \\
\hline $\begin{array}{l}\text { Revenue, Expenditure, Balance and Composition of Financing }{ }^{4}- \\
\text { General Government }{ }^{5}\end{array}$ & A & A & A \\
\hline $\begin{array}{l}\text { Revenue, Expenditure, Balance and Composition of Financing }{ }^{4}- \\
\text { Budgetary Central Government }\end{array}$ & Q & Q & Q \\
\hline Financial balance sheet - Budgetary Central Government & A & A & A \\
\hline Comprehensive list of tax and other revenues $^{6}$ & M & M & M \\
\hline Budget tables & \multicolumn{3}{|c|}{ Submitted to Parliament } \\
\hline Revised budget tables & \multicolumn{3}{|c|}{ Submitted to Parliament } \\
\hline Disposal of non-financial assets and policy lending ${ }^{6}$ & Q & Q & Q \\
\hline Comprehensive list of domestic arrears of the government & SA & SA & SA \\
\hline $\begin{array}{l}\text { Stocks of public sector and public-Guaranteed Debt as compiled by } \\
\text { MINECOFIN and NBR }\end{array}$ & Q & Q & Q \\
\hline External Current Account Balance & A & SA & A \\
\hline Exports and Imports of Goods and subcomponents. & M & M & Q \\
\hline Exports and Imports of Goods and Services and subcomponents & A & A & A \\
\hline \multicolumn{4}{|c|}{$\begin{array}{l}{ }^{3} \text { Both market-based and officially-determined, including discount rates, money market rates, key repo rate (KRR), rates for } \\
\text { standing facilities, rates in repo transactions of the NBR with banks, interbank money market rate, rates on treasury bills, } \\
\text { notes and bonds. }\end{array}$} \\
\hline \multicolumn{4}{|l|}{${ }^{4}$ Foreign, domestic bank, and domestic nonbank financing. } \\
\hline \multicolumn{4}{|c|}{$\begin{array}{l}{ }^{5} \text { The general government consists of the central government (budgetary funds, extra budgetary funds, and social security } \\
\text { funds) and state and local governments. }\end{array}$} \\
\hline \multicolumn{4}{|c|}{$\begin{array}{l}{ }^{6} \text { Includes proceeds from privatization, accompanied by information on entities privatized, date of privatization, numbers } \\
\text { and prices of equities sold to the private sector. }\end{array}$} \\
\hline
\end{tabular}




\section{INTERNATIONAL MONETARY FUND}

\section{RWANDA}

\section{STAFF REPORT FOR THE 2019 ARTICLE IV CONSULTATION}

June 11, 2019

\author{
Approved By \\ Zeine Zeidane and Yan \\ Sun (IMF) and Marcello \\ Estevão (IDA)
}

The Debt Sustainability Analysis (DSA) was prepared jointly by International Monetary Fund (IMF) and International Development Association (IDA) staff, in consultation with the authorities.

\begin{tabular}{|l|c|}
\hline \multicolumn{2}{|c|}{ Rwanda: Risk Rating Summary } \\
\hline \multicolumn{2}{|c|}{ Joint Bank-Fund Debt Sustainability Analysis } \\
\hline Risk of external debt distress & Low \\
\hline Overall risk of debt distress & Low \\
\hline Application of judgment & No \\
\hline
\end{tabular}

An updated joint assessment of Rwanda's debt sustainability suggests continued low risk of external debt distress. External debt burden indicators remain below risk thresholds, except for a short and temporary breach of debt service indicators in 2023, when the Eurobond issued in 2013 matures. The main risk to debt sustainability—and macroeconomic stability—remains external shocks. Balancing Rwanda's still-strong public investment needs with maintaining low risks of debt distress, the government is focused on carefully choosing the highest return projects, financed under the most favorable terms. These principles are laid out in Rwanda's Medium-Term Debt Strategy, as are options for help mitigating potential risks. More broadly, the government is focused on creating a larger and more diversified export base while encouraging more private investment, to help secure high and resilient growth over the long term. Forthcoming results of fiscal risk analysis will help identify if there could be additional contingent liabilities that should be included in the next DSA.

\footnotetext{
${ }^{1}$ This debt sustainability analysis was conducted using the Joint Bank-Fund Debt Sustainability Framework for Low-Income Countries (LIC-DSF) that was approved in 2017. The fiscal year for Rwanda is from July-June; however, this DSA is prepared on a calendar year basis.
} 


\section{BACKGROUND}

1. Rwanda's public and publicly-guaranteed debt has increased, including to support investment scaling up envisaged under the recently completed 2013-18 program supported by the Policy Support Instrument, while maintaining a low risk of debt distress. During that period, guarantees were issued and borrowing undertaken to support a large scaling up of public investment projects to support trade and tourism. These include three large-scale projects which are being completed through a series of PPPs and external guarantees, totaling US $\$ 465$ million at end-2018. ${ }^{2}$ As a result, nominal public and publicly guaranteed (PPG) external debt has risen from 21.8 percent at end-2013 to 41.6 percent in 2018 (Text Figure 1). ${ }^{3}$ The debt continues to be dominated by multilateral lending (Text Figure 2), resulting in a PV of PPG external debt-to-GDP ratio of 29.0 in 2018. Total nominal public debt stood at 53.1 percent of GDP in 2018, which is similar to previous DSA projections. External debt remains about two-thirds on concessional terms. The yield on the outstanding Eurobond has fallen to around 5.8 percent in early-2019, while rates on domestic T-bills and T-bonds range from 5.5 percent (28 days) to 12.9 percent (15 years).

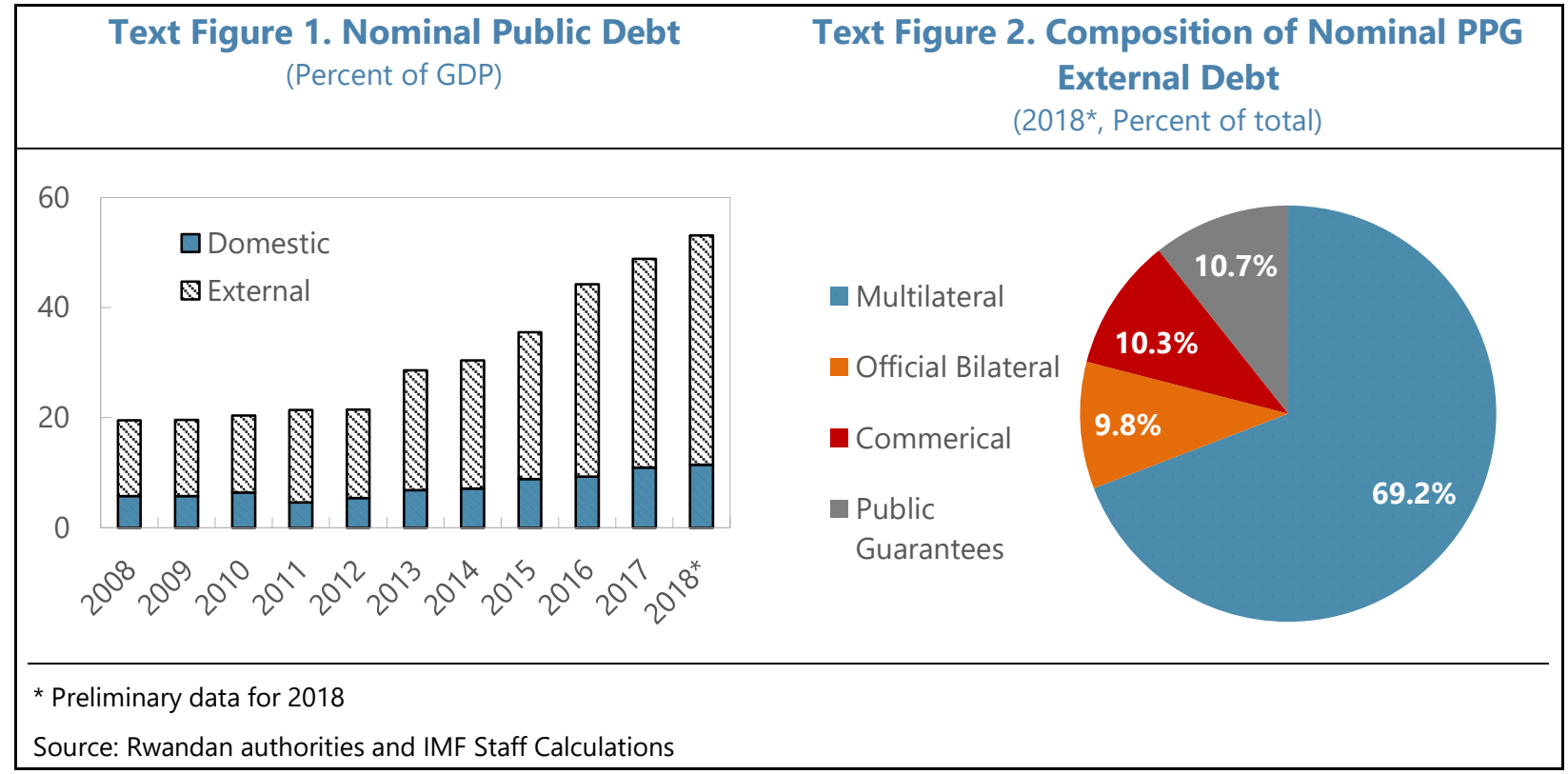

2. The DSA covers the central government, guarantees, and state-owned enterprises (Text

Table 1). The Ministry of Finance and Economic Planning publishes annual debt data, covering domestic and external debt of the central government, broken down by multilateral, bilateral and commercial debt, as well as information on guarantees and debt held by all state-owned enterprises (SOEs). There is no debt

\footnotetext{
2 These projects include: the construction of the Kigali Convention Center (KCC) completed in 2016 (US\$130 million); the expansion of the national airline, RwandAir, including increasing in the size of the fleet (US\$169 million debt outstanding at end-2018; US\$86million in aircraft leases at end-2018); and the construction of a new airport in the Bugesera district of southeastern Rwanda (US $\$ 80$ million).

3 Preliminary data for 2018.
} 
stemming from extra budgetary funds, long term central bank financing of the government, nor the stateowned social security fund. External debt is defined on a currency-basis.

\section{Text Table 1. Rwanda: Coverage of Public and Publicly Guaranteed Debt and Parameters for Contingent Liability Shocks for the Tailored Stress Test}

\begin{tabular}{|l|lc|}
\hline & Subsectors of the Public Sector & Check Box \\
\hline 1 & Central Government & $\mathrm{X}$ \\
$\mathbf{2}$ & State and Local Government & \\
$\mathbf{3}$ & Other Elements in the General Government 1/ & $\mathrm{X}$ \\
$\mathbf{4}$ & o/w: Social Security Fund & $\mathrm{X}$ \\
$\mathbf{5}$ & o/w: Extra Budgetary Funds (EBFs) & $\mathrm{X}$ \\
$\mathbf{6}$ & Guarantees (to Other Entities in the Public and Private Sector, Including to SOEs) \\
7 & Central Bank (Borrowed on Behalf of the Government) 2/ & $\mathrm{X}$ \\
8 & Non-Guaranteed SOE Debt & $\mathrm{X}$ \\
\hline
\end{tabular}

\begin{tabular}{|c|c|c|c|c|c|}
\hline 1 & The Country's Coverage of Public Debt & \multicolumn{4}{|c|}{$\begin{array}{l}\text { The Central Government plus Social Security and Extra Budgetary Funds, } \\
\text { Central Bank, Government-Guaranteed Debt, Non-Guaranteed SOE Debt }\end{array}$} \\
\hline & & \multicolumn{2}{|r|}{ Default } & $\begin{array}{l}\text { Used for the } \\
\text { Analysis }\end{array}$ & $\begin{array}{r}\text { Reasons for Deviations } \\
\text { from Default Settings }\end{array}$ \\
\hline 2 & Other Elements of the General Government not Captured in 1. & 0 & percent of GDP & 0 & \multirow{4}{*}{ SOE debt fully captured. } \\
\hline 3 & SOE's Debt (Guaranteed and not Guaranteed by the Government) 3 / & 2 & percent of GDP & 0 & \\
\hline 4 & PPP 4/ & 35 & percent of PPP stock & 0 & \\
\hline 5 & Financial Market (the Default Value of 5 Percent of GDP is the Minimum Value) & 5 & percent of GDP & 5 & \\
\hline & Total $(2+3+4+5)$ (in Percent of GDP) & \multicolumn{4}{|c|}{5.0} \\
\hline
\end{tabular}

1/ The state-owned social security fund (Rwanda Social Security Board, RSSB) has no outstanding debt and there are no extra-budgetary funds (EBFs). 2/ There is no short-term financing from the central bank (BNR) to the government.

3/ The default shock of 2 percent of GDP will be triggered for countries whose government-guaranteed debt is not fully captured under the country's public debt definition (1.). If it is already included in the government debt (1.) and risks associated with SoE's debt not guaranteed by the government is assessed to be negligible, a country team may reduce this to 0 percent.

4/ When PPP stock is less than 3 percent of GDP, as reflected in the World Bank's database, then test is set to zero. Rwanda's PPP stock is shown as 2 percent of GDP.

Source: Rwandan authorities and World Bank's Private Participation in Infrastructure Database.

\section{UNDERLYING ASSUMPTIONS}

\section{The DSA assumes the adoption of a new fiscal framework, consisting of a debt ceiling} anchor and an operational deficit ceiling. The fiscal framework would: (i) maintain the East African Community 50 percent PV of debt to GDP ceiling as a fiscal anchor; and (ii) introduce an operational rule with deficit to GDP ceiling of 5.5 percent for the budgetary central government (BCG) over a 5 -year rolling window ${ }^{4}$. The BCG deficit ceiling is well below that needed to keep the PV of debt below the ceiling; this is to provide a buffer for unanticipated developments and debt contracted or guaranteed outside the BCG. The fiscal framework is designed to support spending for implementation of Rwanda's National Transformation Strategy (NST), while providing operational guidance and maintaining debt at a sustainable level. As a result, the gross borrowing needs of the public sector have been increased over the DSA horizon, with an assumption that the majority of additional financing would be accessed on concessional terms and used for investment spending (capital and labor). The main assumptions and projections for key macroeconomic variables are summarized in Box 1 and Text Table 2.

\footnotetext{
${ }^{4}$ See staff report for the 2019 Article IV consultation and request for a three-year Policy Coordination Instrument.
} 
4. Despite higher growth in the near-term, the DSA takes a more conservative approach to long-run growth compared to previous DSAs. Growth is expected to be somewhat higher in the near term as compared to the previous DSA, given the assumption of higher investment spending and recent evidence of higher growth potential in agriculture and manufacturing. Over the next five years, the additional investment spending and large construction projects should sustain growth at almost 8.0 percent, before tapering off to around 6.5 percent in 20 years, consistent with an economy where population growth could slow over time. While the public sector is expected to remain the main driver of growth in the near term, the private sector is expected gradually to play a more import role in growth and job creation over time. The current account deficit is expected to remain around 7.5 percent over the medium term, and narrow modestly over the long term as exports in new lines expand (including horticulture, new minerals, and textiles).

Text Table 2. Key Macroeconomic and Debt Assumptions—Comparison with the Previous Debt Sustainability Analysis

\begin{tabular}{|c|c|c|c|c|c|c|c|c|}
\hline Calendar year & 2018 & 2019 & 2020 & 2021 & 2022 & 2025 & 2035 & 2038 \\
\hline & & & & \multicolumn{5}{|c|}{ Projections } \\
\hline \multicolumn{9}{|c|}{$\begin{array}{l}\text { Selected indicators from the macro-frame and debt data } \\
\text { (Percent, unless otherwise indicated) }\end{array}$} \\
\hline \multicolumn{9}{|c|}{ PV of PPG External Debt to GDP Ratio } \\
\hline 2018 DSA 9th Rev. & 29.9 & 29.4 & 28.2 & 26.7 & 26.2 & 25.1 & 23.9 & 23.4 \\
\hline 2019 DSA & 29.0 & 29.4 & 29.6 & 29.4 & 29.6 & 31.1 & 33.8 & 34.4 \\
\hline \multicolumn{9}{|c|}{ PV of Public Debt to GDP Ratio } \\
\hline 2018 DSA 9th Rev. & 39.6 & 38.7 & 37.0 & 35.2 & 33.3 & 31.6 & 31.8 & 31.9 \\
\hline 2019 DSA & 41.1 & 42.5 & 42.9 & 42.7 & 41.6 & 40.9 & 45.1 & 46.7 \\
\hline \multicolumn{9}{|c|}{ Grant Element of New External Borrowing } \\
\hline 2018 DSA 9th Rev. & 48.9 & 48.6 & 41.8 & 40.2 & 40.9 & 39.7 & 30.8 & 28.2 \\
\hline 2019 DSA & - & 46.4 & 44.4 & 42.7 & 40.4 & 41.4 & 33.8 & 30.0 \\
\hline \multicolumn{9}{|c|}{ New Commercial Loan Disbursements (billions of U.S. dollars) } \\
\hline 2018 DSA 9th Rev. & 0.04 & 0.04 & 0.05 & 0.06 & 0.04 & 0.50 & 1.68 & 2.67 \\
\hline 2019 DSA & 0.04 & 0.00 & 0.00 & 0.00 & 0.00 & 0.41 & 1.07 & 1.83 \\
\hline \multicolumn{9}{|c|}{ Real GDP Growth (annual percent change) } \\
\hline 2018 DSA 9th Rev. & 7.2 & 7.8 & 8.0 & 7.5 & 7.5 & 7.5 & 7.5 & 7.5 \\
\hline 2019 DSA & 8.6 & 7.8 & 8.1 & 8.2 & 8.0 & 7.4 & 6.9 & 6.6 \\
\hline \multicolumn{9}{|c|}{ Current Account Balance (percent of GDP) } \\
\hline 2018 DSA 9th Rev. & -10.0 & -10.0 & -9.0 & -7.1 & -7.1 & -5.0 & -5.4 & -5.5 \\
\hline 2019 DSA & -7.9 & -9.6 & -9.4 & -7.9 & -8.1 & -7.7 & -7.2 & -7.1 \\
\hline \multicolumn{9}{|c|}{ Exports of goods and services (percent of GDP) } \\
\hline 2018 DSA 9th Rev. & 22.5 & 23.7 & 23.9 & 24.9 & 24.9 & 27.9 & 39.5 & 43.8 \\
\hline 2019 DSA & 21.4 & 21.2 & 21.4 & 22.1 & 22.1 & 23.7 & 29.4 & 31.7 \\
\hline \multicolumn{9}{|c|}{ Fiscal balance (percent of GDP) } \\
\hline 2018 DSA 9th Rev. & -5.8 & -4.1 & -3.4 & -2.7 & -2.6 & -3.2 & -2.5 & -2.5 \\
\hline 2019 DSA & -4.7 & -6.1 & -6.4 & -6.2 & -5.1 & -5.4 & -5.3 & -5.2 \\
\hline
\end{tabular}




\section{The DSA assumes continued support from bilateral and multilateral development partners} over the medium-term. The new fiscal framework should provide space to support NST implementation, while maintaining macroeconomic stability. Over the first 5 years of the DSA horizon, larger financing needs of the government are expected to be met by increased support from official bilateral and multilateral partners. From 2025 onwards, the financing mix is assumed to: (i) shift gradually away from concessional financing to market-based financing, as income levels rise, and (ii) shift from external to domestic financing, as the local bond markets develop.

6. The DSA also takes a conservative approach to financing mix (Text Table 3). The grant component of new external financing is assumed to decline as Rwanda develops. As a result, grantequivalent external financing ${ }^{5}$ declines from 71 percent of total external financing in 2019 to 58 percent in 2028 to 39 percent by 2039, while average effective real interest rates on domestic debt rise from 1.6 percent in 2009-18 to 3.4 percent in 2030-39.

Text Table 3. Financing Mix (2019-39)

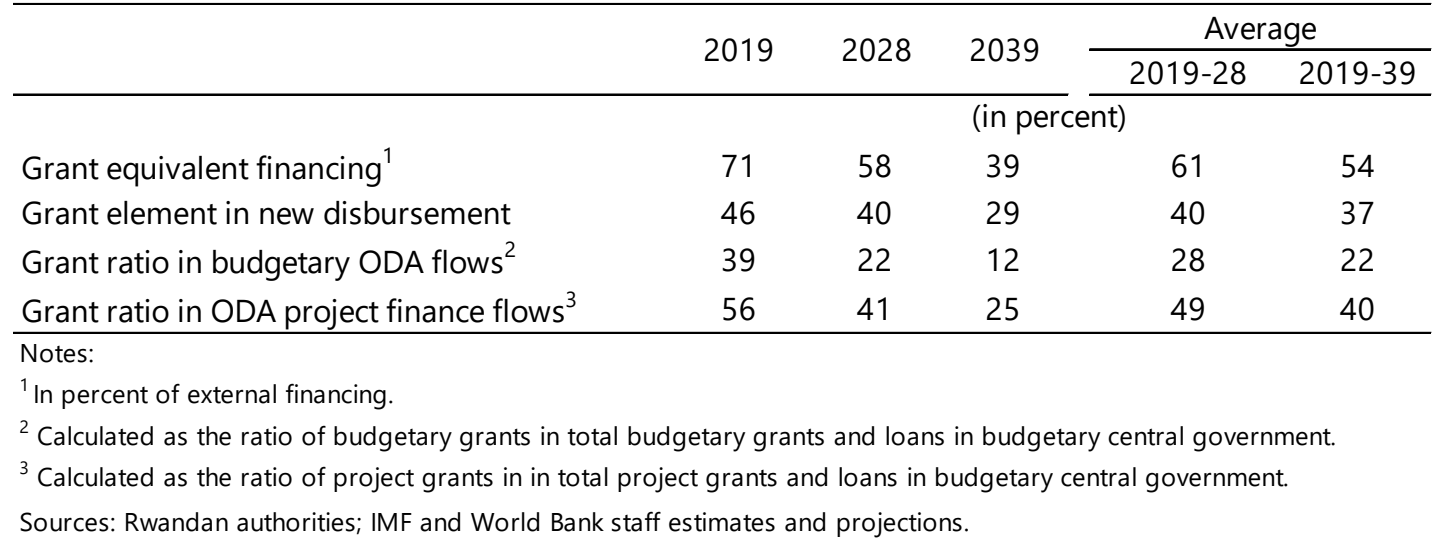

\section{Rwanda's recent public investment drive has resulted in large accrual of public debt, but has} been appropriately managed in order to keep debt risks low. A scaling up of public debt, among other things to finance large projects, was anticipated in the 2013 DSA, with Rwanda's debt sustainability assessed against different borrowing scenarios to determine the fiscal space available. ${ }^{6}$ The actual pace of the scaling up of debt was larger than anticipated in the scaling up scenarios of the 2013 DSA. Faster exchange rate depreciation agreed under the PSI/SCF to correct external imbalances, and higher primary deficits, due to lower-than-assumed donor grants, were the main factors in the larger-than-expected accrual of debt (Figure 3).

\footnotetext{
5 This includes grants provided directly to the government as well as the grant element of new borrowing (difference between the face value and the PV of new debt).

${ }^{6}$ See "Appendix II. Joint Bank-Fund Staff Debt Sustainability Analysis Update" of the Seventh the Seventh Review Under The Policy Support Instrument for Rwanda, December 2013:

https://www.imf.org/external/pubs/ft/scr/2013/cr13372.pdf
} 


\section{Box 1. Macroeconomic Framework for the DSA}

The medium- and long- term framework underpinning the DSA assumes that Rwanda continues to enjoy robust growth, with low and stable inflation. A limited growth dividend is implied from the broad public investment in infrastructure to support greater export diversification, and to improve agricultural productivity and resilience. Mobilizing the private sector as the main engine for growth and job creation will be critical, along with sustained levels of investment-consistent with the NST or meeting the MDGs—and increased human capital. Key highlights include:

Growth: The near-term growth outlook maintains growth around 8 percent through 2022, declining to 7.2 percent by 2028 , and to 6.5 percent by 2039. Relative to previous DSAs, this is a slight upward revision to growth in the near term, but a more conservative growth projection over the medium- to long- term, consistent with an economy where population growth is slowing over time. Upside risks around the long-term growth potential of the economy exist, particularly from faster TFP growth.

External Sector: Exports of goods and services are expected to grow steadily (11 percent on average during 2019-39), roughly in line with historical rates, but below recent very rapid growth. This reflects, in part, strategic public investments and export promotion, and development plans. Import needs are expected to remain high, particularly in the near term as high public and private investment rates are maintained, declining slightly over the medium term. Consequently, while Rwanda's current account is projected to remain in deficit, it is expected to narrow somewhat over the DSA horizon, reaching 7 percent by 2039.

Inflation: Inflation is expected to remain at the authorities' medium-term target of 5 percent over the medium- to long- run.

Reserves: Reserve coverage is expected to remain in the range of $4-5$ months of prospective imports over 2020-22 and remain above 4.5 months of imports in the outer years.

Domestic Revenue Mobilization. There is assumed to be a gradual rise in domestic revenues, from 19.3 percent in 2018 to 22.3 percent by 2039, reflecting tax revenue measures already in the pipeline (e.g. fixed asset taxes, electronic billing machines), as well as additional measures agreed under the new program (e.g. tax expenditure analysis aimed to streamline incentives, additional administrative measures.

Grants. The DSA assumes a tapering of external assistance from development partners over the projection period. Grants decline steadily from 4.9 percent of GDP in 2018 to 2.3 percent by 2029, and 1.1 percent by 2039.

Public Spending and Deficit: The fiscal deficit is assumed to average slightly below the 5.5 percent of GDP ceiling over the duration of the forecast horizon, resulting in higher gross borrowing needs of the public sector as compared to previous DSAs.

External borrowing. The assumptions for new external borrowing vary over the assessment period. With development of local bond markets and some improvement in the current account position, reliance on external borrowing is expected to moderate. Compositionally, from 2019-2022, the framework assumes higher public borrowing needs, which are met by increased disbursements of external multilateral and bilateral debt. From 2022 onward, the framework assumes that such needs will be financed with a progressively larger share of nonconcessional borrowing. The share of external financing relative to total financing declines from around 61 percent in 2019 to 55 percent by 2029 and remains at around 55 percent thereafter. The Eurobond is assumed to be rolled over in 2023, and again in 2033, at an interest rate of 7 percent and a maturity of 10 years.

Domestic borrowing. The framework assumes that, over the medium- to long-term, net domestic borrowing will increase with a gradual lengthening of maturities, as Rwanda intensifies efforts to develop the domestic bond market. New domestic borrowing is expected to be contracted at an average nominal interest rate of 7.9 percent over the next five years, rising gradually to 8.3 percent in the long run as the government shifts to longer maturities.

Foreign Direct Investment. The framework assumes an increase in FDI, driven by the NST, the Compact with Africa, and other efforts to provide incentives to attract foreign direct investment. FDI increases from 3 percent of GDP in 2018 to 4.5 percent by 2039 


\section{Realism tests illustrate the near-term growth contribution of higher investment spending} for the NST and agricultural productivity (Figure 4). Compared to the previous DSA, the primary fiscal deficit is 2.0 percentage points of GDP higher in 2022, reflecting higher investment spending. The addition to growth is less than would be implied by the additional fiscal impulse. This DSA assumes an unchanged direct growth contribution from the construction of Bugesera airport. Compared to the previous DSA, there is more public investment which has a direct impact on growth. ${ }^{7}$

\section{Rwanda's debt carrying capacity is assessed as "strong"8 (Text Tables 4a and b). The} composite index $(\mathrm{Cl})$ for Rwanda, which measures the debt carrying capacity in the new LIC-DSF, stands at 3.24 , above the cut-off value of 3.05 for strong capacity countries. Underlying inputs for the calculation of the $\mathrm{Cl}$ were sourced from the IMF's October 2018 WEO, and an update of the World Bank Country Policy and Institutional Assessment (CPIA) to 2017 levels. The Cl score is driven largely by Rwanda's high CPIA score and adequate reserve coverage. ${ }^{9}$ The government's medium-term debt strategy (MTDS) for FY18/19-FY20/21 examines various potential risks to debt sustainability, including rolling over the Eurobond in 2023. For contingency planning should potential risk scenarios materialize, the MTDS outlines several alternative debt management strategies. Overall, risks to debt sustainability are mitigated by a large average time-to-maturity for the entire portfolio of 12 years, reflecting the large share of concessional external borrowing and the increasing average maturity of domestic debt, as well as the relatively small size of the Eurobond. The MTDS underscores the importance of maintaining a low risk of debt distress in order to maintain concessional financing windows by several development partners, and that non-concessional borrowing will be contracted only on an exceptional basis, cognizant of debt limits in the IMF-supported program and based on a careful consideration of the economic rate of return of proposed projects.

\begin{tabular}{|c|c|c|c|c|}
\hline \multicolumn{5}{|c|}{ Text Table 4a. Rwanda: Debt Carrying Capacity } \\
\hline Components & Coefficients (A) & $\begin{array}{c}\text { 10-year average values } \\
\text { (B) }\end{array}$ & $\begin{array}{c}\text { CI Score components } \\
\qquad\left(A^{*} B\right)=(C)\end{array}$ & $\begin{array}{l}\text { Contribution of } \\
\text { components }\end{array}$ \\
\hline CPIA & 口貯 & ㅁापा & 미 & एा \\
\hline Real growth rate & & & & \\
\hline $\begin{array}{c}\text { (in percent) } \\
\text { Import coverage of reserves }\end{array}$ & 口 पा山 & पाप & वाप & Ш \\
\hline & पा山ा & एवाप्य & वाप & $\square$ \\
\hline $\begin{array}{l}\text { (in percent) } \\
\text { Remittances }\end{array}$ & पण口 पा & एामा & एव & 따 \\
\hline (in percent) & 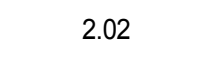 & पाप & पा山 & $\square$ \\
\hline (in percent) & पाण & पाण & 口ा एव & $\square$ \\
\hline Cl Score & & & ㅁIII & $\square \square \square$ \\
\hline Cl rating & & & Strong & \\
\hline
\end{tabular}

\footnotetext{
7 The Bugesera effect is calculated by applying a fiscal multiplier of 0.3 to the total value of the Bugesera Project (US\$397.5 million) over the 3-year life of the project (2019-21), as a share of cumulative GDP.

8 This is unchanged from the assessment in the previous DSA, under the old methodology.

${ }^{9}$ This is based on the IMF's ARA metric for Rwanda's reserve coverage.
} 


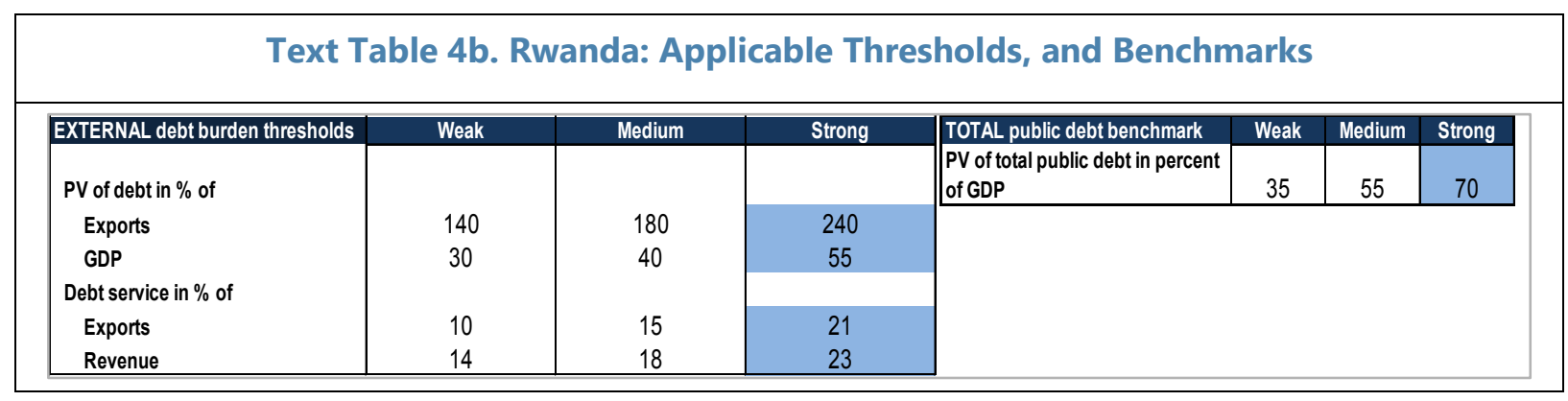

\section{DEBT SUSTAINABILITY ANALYSIS}

\section{External Debt}

10. Rwanda's external debt stock indicators remain below the threshold under the baseline and all stress scenarios. The higher investment spending provided for under the revised framework is expected to lead to a gradual accumulation of PPG external debt over time, with the present value (PV) of debt peaking at 34.6 percent of GDP in 2039 (Table 1). The PV of external debt-to GDP (PVDY) and the PV of external debt-to-exports (PVDE) remain well below their respective thresholds of 55 and 240 percent, respectively, throughout the projection period and under all the standardized shocks (Figure 1). ${ }^{10}$ The PVDY rises gradually to 33.0 percent by 2029, while the PVDE ratio declines to 126.2 percent (Table 3), consistent with the NST strategy for more export diversification and job creation in the tradable sector. The most severe shocks are the export (for the PVDE) and combination shocks (for the PVDY).

\section{The historical scenario increases sharply as a result of the sharp adjustment of external} balances over the period 2015-17 (Table 3). The PVDY and PVDE ratios both rise sharply and continuously under the historical scenario. This is due primarily to the large current account deficit and negative GDP deflator calibrated using historical averages, which covered a period including several large shocks (donor withdrawal, commodity prices, and drought) as well as large external imbalances, which were corrected over the 2015-17, primarily through a large exchange rate adjustment, as envisaged under the PSI/SCF-supported program. After the large exchange rate adjustment, the real exchange rate is now well aligned with fundamentals and the government is committed to maintaining that alignment to preserve external sustainability. The large current account deficit and negative GDP deflator account for almost all of the divergence between the baseline and historical scenarios in these stock indicators.

\section{The standardized stress tests confirm that risks related to the debt service burden and} market financing are low (Figure 1). The servicing spike in external debt service in 2023 (due to rolling over the Eurobond) causes breaches to both the debt service-to-exports (DSE) ratio and the debt service-

\footnotetext{
10 The new LIC-DSF, similar to the previous one, assesses the risk of debt distress by observing the evolution of selected indicators against predetermined thresholds that are set according to countries' debt carrying capacities. The indicators are identical to those in the previous LIC-DSF, with the exception of the PV of debt-to-government revenues (PVDR), which is no longer used. This was dropped as it was found to add no new information in the process of determining the risk of debt distress. See joint IMF / World Bank Paper on Review of the Debt Sustainability Framework for Low Income Countries: Proposed Reforms, October 2017.
} 
to-revenue (DSR) ratio under the stress tests (and baseline). ${ }^{11}$ The breaches are temporary in nature (lasting one year), and thus, according to the LIC DSF guidance note, are assumed not to affect the risk rating. ${ }^{12}$ The standardized shock to gross market financing needs (Figure 5 ) does not materially alter the debt indicators.

\section{Customized alternate scenarios suggest that these results are robust to a variety of other} financing conditions, although concessional financing remains an important element of the authorities' medium-term debt strategy. The external debt indicators are reproduced under two customized alternate scenarios, which effectively constitute additional stress testing (Figure 6). The first scenario assumes that the Rwandan government is required to take on the full financial liability for Bugesera airport in 2023. The second scenario assumes that all additional borrowing required by the proposed fiscal framework is contracted on commercial Eurobond terms, assuming a maturity of 10 years and an interest rate of 7 percent, compared to 5.8 percent currently. Under both alternate scenarios, the external debt stock indicators remain well below their respective thresholds, while the debt service indicators show the same one period breach as before.

\section{Public Debt}

14. Public debt remains significantly below the LIC DSA benchmark of $\mathbf{7 0}$ percent (in PV terms) for countries with strong debt carrying capacity (Table 2 and $\mathbf{4 a}$ and $\mathbf{b}$, Figure 2). The evolution of the both the stock and service indicators for public debt follows broadly that of external debt. Public debt remains sustainable even under the most extreme shocks scenarios (real GDP growth and export growth shocks). The PV of public debt-to-revenue ratio (PVDR) remains broadly stable despite a steady real decline in grants (which are included in the ratio). The debt service-to-revenue (DSR) ratio increases steadily over the forecast horizon, due to a greater reliance on domestic debt.

\section{ASSESSMENT}

15. Rwanda's debt is assessed to be sustainable with continued low risk of debt distress. The risk of PPG external debt distress in Rwanda is low, and public debt remains well below its benchmark. A temporary breach in the debt service ratios reflects refinancing of the Eurobond. Given the relatively small size of the Eurobond and the low sovereign risk premium, the rollover risks are limited. A forthcoming Fiscal Transparency Evaluation and subsequent fiscal risk analysis will help evaluate whether there could be additional contingent liabilities not captured in this analysis.

\section{The main risks to debt sustainability, and indeed the overall macroeconomic outlook} continue to be external shocks. The baseline scenario assumes Rwanda continues to achieve robust growth over the medium and long term, while concessional financing is expected to decline gradually. Main risks to this outlook are external shocks to growth and/or exports, lower-than-expected concessional financing, and worse-than-expected external financing conditions. A series of stress tests conducted in this

\footnotetext{
${ }^{11}$ The new LIC DSF framework has lowered the threshold for the external debt service-to-exports (DSE) ratio from 25 to 21 , which partly contributes to the one-period breach in this indicator.

12 The DSA focuses on gross debt flows. With expectations that the Eurobond will be rolled over, there is a spike down in the grant element of new borrowing in 2023, and no anticipated net effect on the debt stock.
} 
debt sustainability analysis, however, shows that these risks do not have a material impact on the overall assessment of Rwanda's debt sustainability.

\section{Authorities' Views}

17. The government is in broad agreement with the DSF results on Rwanda's debt portfolio. Rwanda's risk of debt distress remains low, and the government intends to keep the status unchanged through a prudent borrowing strategy. The government will maximize concessional loans to avoid pressure on its debt repayment profile which shows a temporary breach in 2023 due to the repayment of the Eurobond. The medium-term debt strategy will also be characterized by a domestic debt issuance plan which will continue to play an essential role in domestic capital development. 


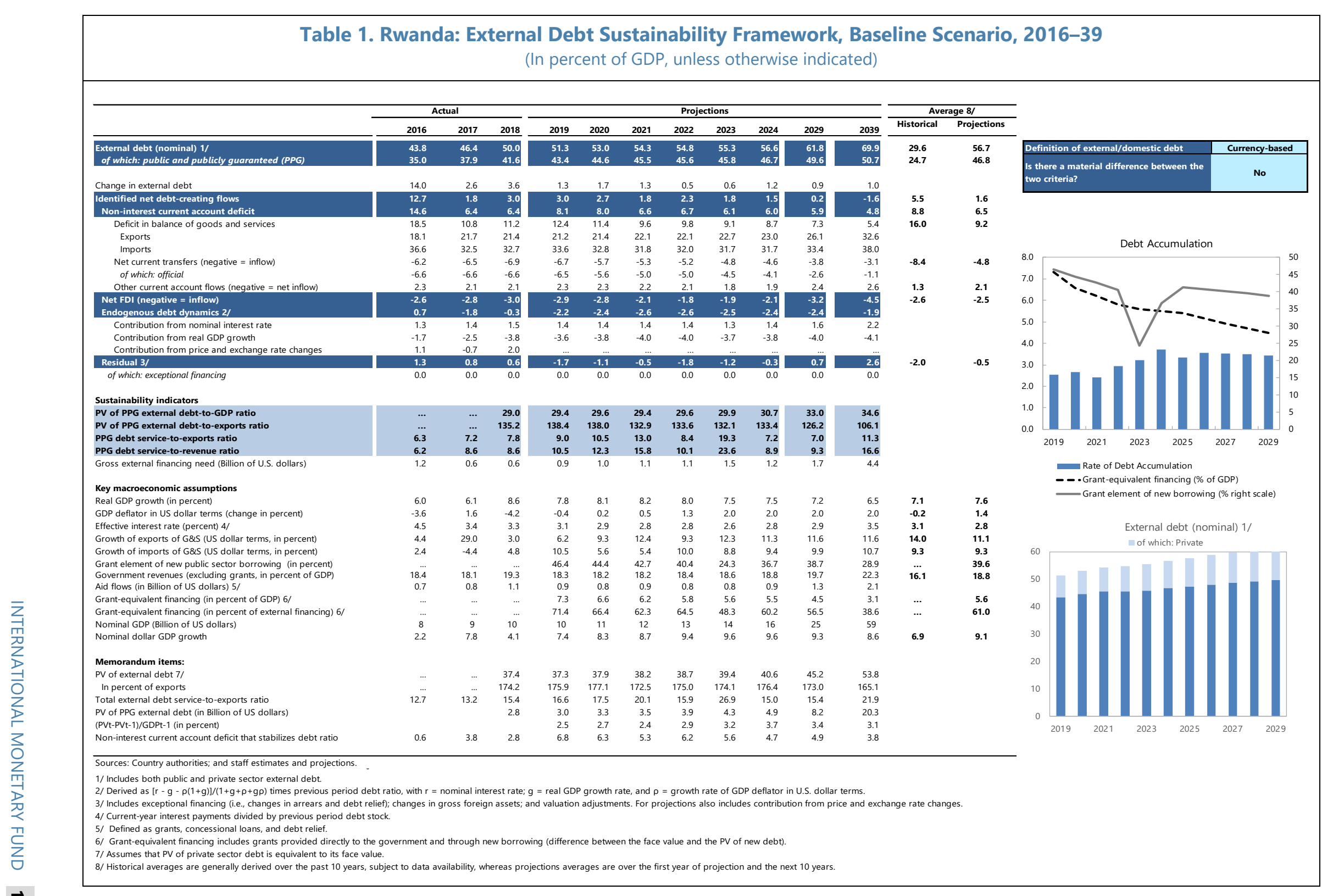




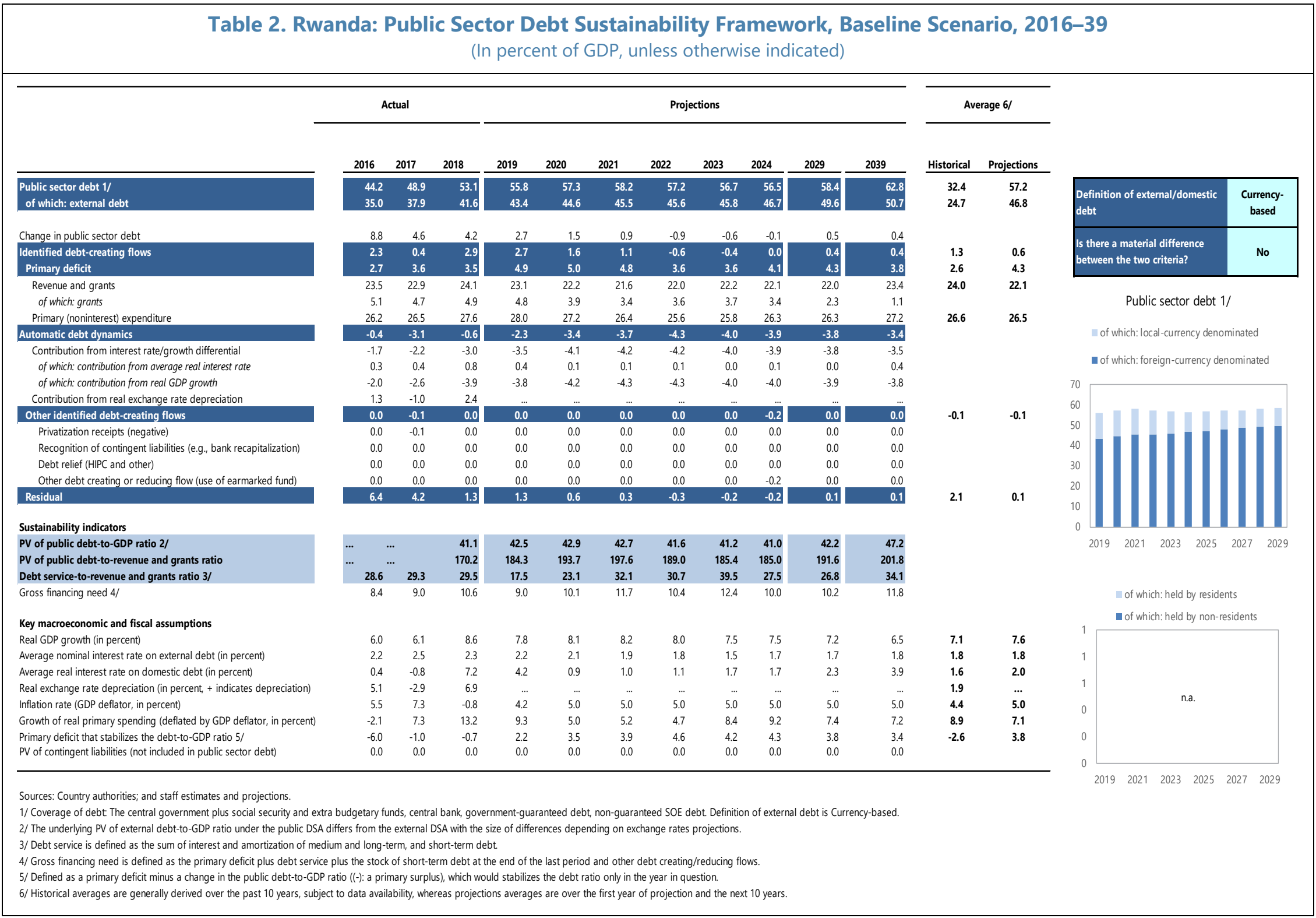


Figure 1. Rwanda: Indicators of Public and Publicly Guaranteed External Debt Under Alternative Scenarios, 2019-29 1/2/
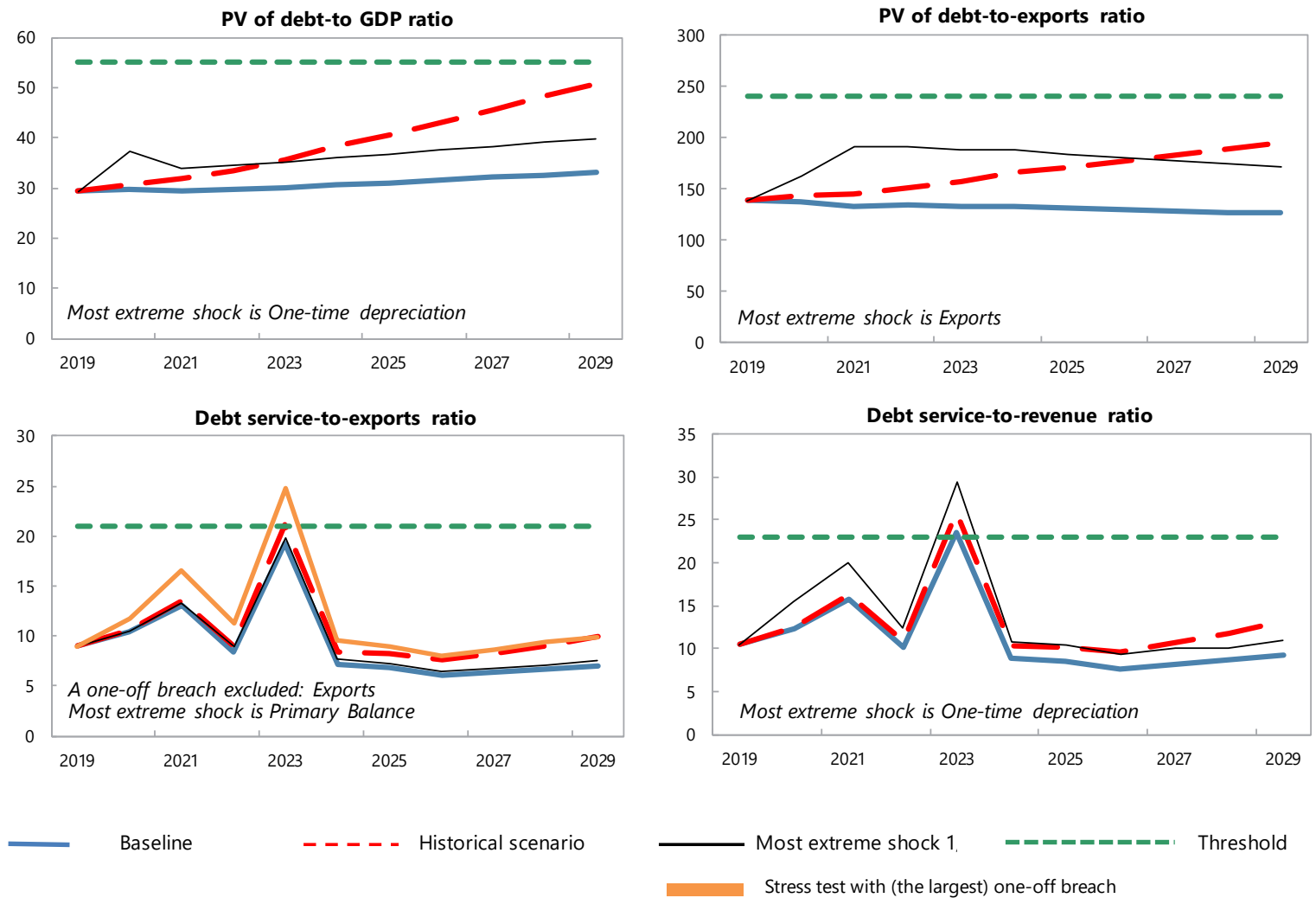

\begin{tabular}{|c|c|c|}
\hline \multicolumn{3}{|c|}{ Customization of Default Settings } \\
\hline & Size & Interactions \\
\hline \multicolumn{3}{|l|}{ Tailored Tests } \\
\hline Combined CLs & Yes & \\
\hline Natural Disasters & n.a. & n.a. \\
\hline Commodity Prices ${ }^{2 /}$ & n.a. & n.a. \\
\hline Market Financing & No & No \\
\hline
\end{tabular}

Note: "Yes" indicates any change to the size or interactions of the default settings for the stress tests. "n.a." indicates that the stress test does not apply.

\begin{tabular}{|lcc|}
\hline \multicolumn{2}{|c|}{ Borrowing Assumptions for Stress Tests* } \\
\hline & Default & User defined \\
Shares of marginal debt & & \\
\hline External PPG MLT debt & $100 \%$ & \\
Terms of marginal debt & $1.8 \%$ & $1.8 \%$ \\
Avg. nominal interest rate on new borrowing in USD & $5.0 \%$ & $5.0 \%$ \\
USD Discount rate & 29 & 29 \\
Avg. maturity (incl. grace period) & 6 & 6 \\
\hline Avg. grace period & & \\
\hline
\end{tabular}

* Note: All the additional financing needs generated by the shocks under the stress tests are assumed to be covered by PPG external MLT debt in the external DSA. Default terms of marginal debt are based on baseline 10-year projections.

Sources: Country authorities; and staff estimates and projections.

1/ The most extreme stress test is the test that yields the highest ratio in or before 2029. Stress tests with one-off breaches are also presented (if any), while these one-off breaches are deemed away for mechanical signals. When a stress test with a one-off breach happens to be the most exterme shock even after disregarding the one-off breach, only that stress test (with a one-off breach) would be presented.

2/ The magnitude of shocks used for the commodity price shock stress test are based on the commodity prices outlook prepared by the IMF research department. 
Figure 2. Rwanda: Indicators of Public Debt Under Alternative Scenarios, 2019-29 1/

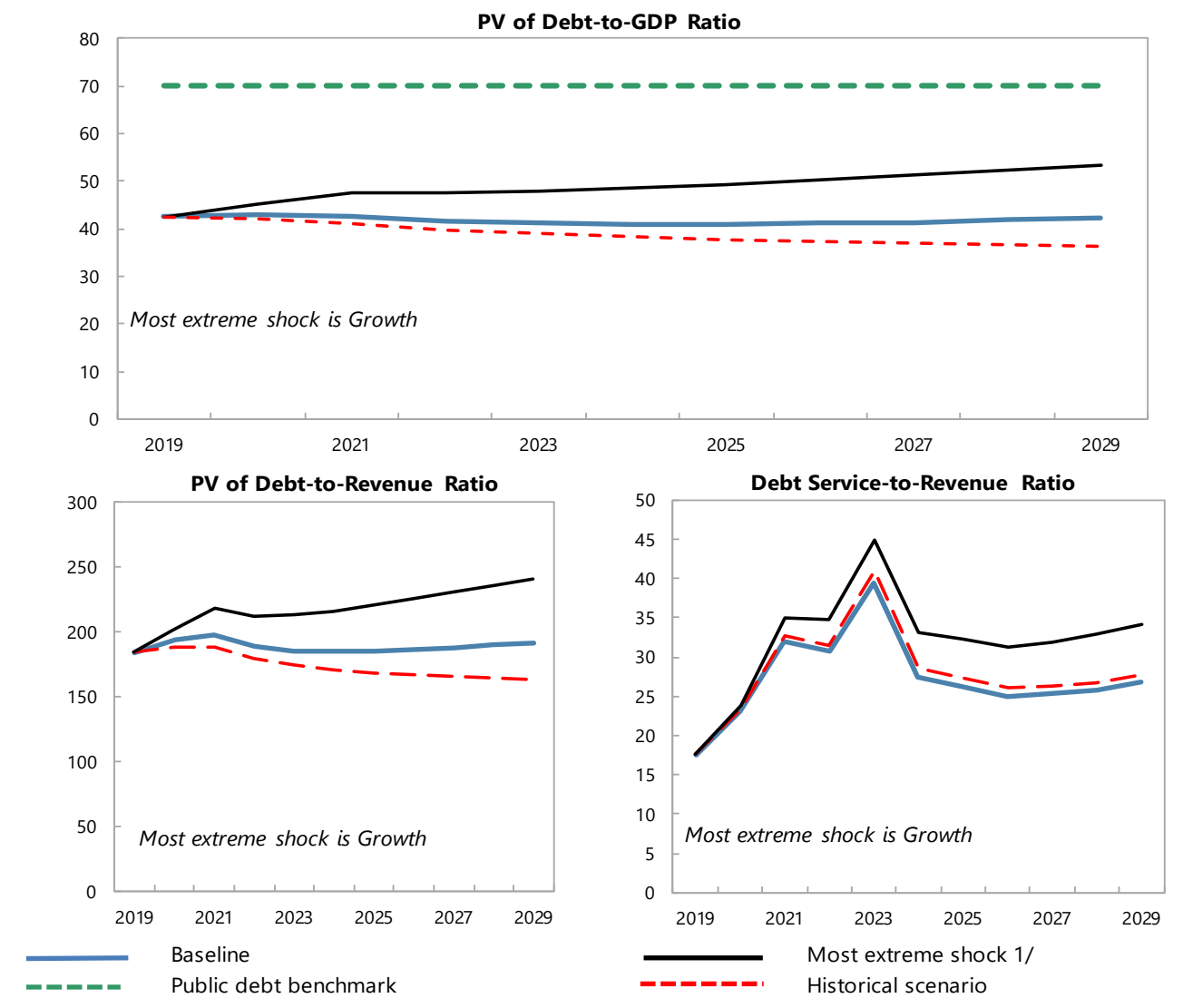

\begin{tabular}{|l|c|c|}
\hline \multicolumn{1}{|c|}{ Borrowing Assumptions for Stress Tests* } & Default & User defined \\
\hline Shares of marginal debt & & \\
External PPG medium and long-term & $58 \%$ & $58 \%$ \\
Domestic medium and long-term & $15 \%$ & $15 \%$ \\
Domestic short-term & $27 \%$ & $27 \%$ \\
\hline Terms of marginal debt & & \\
\hline External MLT debt & $1.8 \%$ & $1.8 \%$ \\
Avg. nominal interest rate on new borrowing in USD & 29 & 29 \\
Avg. maturity (incl. grace period) & 6 & 6 \\
Avg. grace period & $5.5 \%$ & $5.5 \%$ \\
Domestic MLT debt & 3 & 3 \\
Avg. real interest rate on new borrowing & 2 & 2 \\
Avg. maturity (incl. grace period) & & $1.0 \%$ \\
\hline Avg. grace period & $1 \%$ & \\
Domestic short-term debt & & \\
Avg. real interest rate & & \\
\hline
\end{tabular}

* Note: The public DSA allows for domestic financing to cover the additional financing needs generated by the shocks under the stress tests in the public DSA. Default terms of marginal debt are based on baseline 10-year projections.

Sources: Country authorities; and staff estimates and projections.

$1 /$ The most extreme stress test is the test that yields the highest ratio in or before 2029. The stress test with a one-off breach is also presented (if any), while the one-off breach is deemed away for mechanical signals. When a stress test with a one-off breach happens to be the most exterme shock even after disregarding the one-off breach, only that stress test (with a one-off breach) would be presented. 
Table 3. Rwanda: Sensitivity Analysis for Key Indicators of Public and Publicly Guaranteed External Debt, 2019-29

(In percent)

\begin{tabular}{|c|c|c|c|c|c|c|c|c|c|c|c|}
\hline & \multicolumn{11}{|c|}{ Projections } \\
\hline & 2019 & 2020 & 2021 & 2022 & 2023 & 2024 & 2025 & 2026 & 2027 & 2028 & 2029 \\
\hline \multicolumn{12}{|c|}{ PV of debt-to GDP ratio } \\
\hline Baseline & 29.4 & 29.6 & 29.4 & 29.6 & 29.9 & 30.7 & 31.1 & 31.6 & 32.1 & 32.6 & 33.0 \\
\hline $\begin{array}{l}\text { A. Alternative Scenarios } \\
\text { A1. Key variables at their historical averages in 2019-2039 1/ }\end{array}$ & 29.4 & 30.6 & 31.9 & 33.5 & 35.6 & 38.3 & 40.5 & 43.0 & 45.6 & 48.2 & 50.8 \\
\hline \multicolumn{12}{|l|}{ B. Bound Tests } \\
\hline B1. Real GDP growth & 29.4 & 30.7 & 31.8 & 31.9 & 32.3 & 33.1 & 33.6 & 34.2 & 34.7 & 35.2 & 35.6 \\
\hline B2. Primary balance & 29.4 & 30.1 & 31.6 & 31.9 & 32.2 & 33.0 & 33.3 & 33.8 & 34.2 & 34.5 & 34.8 \\
\hline B3. Exports & 29.4 & 31.2 & 33.8 & 33.8 & 33.9 & 34.5 & 34.7 & 35.1 & 35.4 & 35.5 & 35.6 \\
\hline B4. Other flows 2/ & 29.4 & 31.6 & 32.9 & 32.9 & 33.1 & 33.7 & 33.9 & 34.4 & 34.7 & 34.9 & 35.0 \\
\hline B6. One-time 30 percent nominal depreciation & 29.4 & 37.4 & 34.0 & 34.4 & 35.0 & 36.1 & 36.7 & 37.5 & 38.3 & 39.1 & 39.8 \\
\hline B6. Combination of B1-B5 & 29.4 & 33.5 & 34.0 & 34.0 & 34.3 & 35.1 & 35.4 & 36.0 & 36.4 & 36.7 & 37.0 \\
\hline \multicolumn{12}{|l|}{ C. Tailored Tests } \\
\hline C1. Combined contingent liabilities & 29.4 & 31.4 & 31.7 & 31.9 & 32.3 & 33.1 & 33.4 & 33.9 & 34.4 & 34.7 & 35.0 \\
\hline C2. Natural disaster & n.a. & n.a. & n.a. & n.a. & n.a. & n.a. & n.a. & n.a. & n.a. & n.a. & n.a. \\
\hline C3. Commodity price & n.a. & n.a. & n.a. & n.a. & n.a. & n.a. & n.a. & n.a. & n.a. & n.a. & n.a. \\
\hline C4. Market Financing & 29.4 & & & & & & & & & & \\
\hline Threshold & 55 & 55 & 55 & 55 & 55 & 55 & 55 & 55 & 55 & 55 & 55 \\
\hline \multicolumn{12}{|c|}{ PV of debt-to-exports ratio } \\
\hline Baseline & 138.4 & 138.0 & 132.9 & 133.6 & 132.1 & 133.4 & 131.0 & 129.8 & 128.4 & 127.5 & 126.2 \\
\hline \multicolumn{12}{|l|}{ A. Alternative Scenarios } \\
\hline A1. Key variables at their historical averages in 2019-2039 1/ & 138.4 & 142.7 & 144.3 & 151.2 & 157.2 & 166.6 & 170.9 & 176.7 & 182.3 & 188.4 & 194.5 \\
\hline \multicolumn{12}{|l|}{ B. Bound Tests } \\
\hline B1. Real GDP growth & 138.4 & 138.0 & 132.9 & 133.6 & 132.1 & 133.4 & 131.0 & 129.8 & 128.4 & 127.5 & 126.2 \\
\hline B2. Primary balance & 138.4 & 140.8 & 143.0 & 144.0 & 142.1 & 143.2 & 140.3 & 138.5 & 136.5 & 134.9 & 133.1 \\
\hline B3. Exports & 138.4 & 162.9 & 191.5 & 191.3 & 187.6 & 187.9 & 183.4 & 180.5 & 177.1 & 174.1 & 171.0 \\
\hline B4. Other flows 2/ & 138.4 & 147.5 & 148.8 & 148.8 & 146.1 & 146.5 & 143.1 & 141.0 & 138.5 & 136.3 & 134.1 \\
\hline B6. One-time 30 percent nominal depreciation & 138.4 & 138.0 & 121.5 & 122.8 & 122.0 & 124.0 & 122.4 & 121.8 & 121.0 & 120.9 & 120.5 \\
\hline B6. Combination of B1-B5 & 138.4 & 156.2 & 140.6 & 157.6 & 155.2 & 156.2 & 153.0 & 151.2 & 148.8 & 147.1 & 145.2 \\
\hline \multicolumn{12}{|l|}{ C. Tailored Tests } \\
\hline C1. Combined contingent liabilities & 138.4 & 146.7 & 143.0 & 144.0 & 142.8 & 143.9 & 141.1 & 139.3 & 137.3 & 135.9 & 134.1 \\
\hline C2. Natural disaster & n.a. & n.a. & n.a. & n.a. & n.a. & n.a. & n.a. & n.a. & n.a. & n.a. & n.a. \\
\hline C3. Commodity price & n.a. & n.a. & n.a. & n.a. & n.a. & n.a. & n.a. & n.a. & n.a. & n.a. & n.a. \\
\hline C4. Market Financing & 138.4 & & & & & & & & & & \\
\hline Threshold & 240 & 240 & 240 & 240 & 240 & 240 & 240 & 240 & 240 & 240 & 240 \\
\hline & rvice-to & exports & ratio & & & & & & & & \\
\hline Baseline & 9.0 & 10.5 & 13.0 & 8.4 & 19.3 & 7.2 & 6.8 & 6.1 & 6.3 & 6.6 & 7.0 \\
\hline A. Alternative Scenarios & & & & & & & & & & & \\
\hline A1. Key variables at their historical averages in 2019-2039 1/ & 9.0 & 10.6 & 13.5 & 9.1 & 21.2 & 8.4 & 8.2 & 7.6 & 8.3 & 9.1 & 9.9 \\
\hline B. Bound Tests & & & & & & & & & & & \\
\hline B1. Real GDP growth & 9.0 & 10.5 & 13.0 & 8.4 & 19.3 & 7.2 & 6.8 & 6.1 & 6.3 & 6.6 & 7.0 \\
\hline B2. Primary balance & 9.0 & 10.5 & 13.2 & 8.9 & 19.8 & 7.7 & 7.2 & 6.4 & 6.7 & 7.1 & 7.5 \\
\hline B3. Exports & 9.0 & 11.8 & 16.6 & 11.2 & 24.8 & 9.6 & 9.0 & 8.0 & 8.6 & 9.4 & 9.9 \\
\hline B4. Other flows 2/ & 9.0 & 10.5 & 13.2 & 8.8 & 19.7 & 7.6 & 7.1 & 6.3 & 6.9 & 7.3 & 7.7 \\
\hline B6. One-time 30 percent nominal depreciation & 9.0 & 10.5 & 13.0 & 8.1 & 19.0 & 7.0 & 6.6 & 5.9 & 6.1 & 6.1 & 6.6 \\
\hline B6. Combination of B1-B5 & 9.0 & 11.1 & 14.8 & 9.6 & 21.8 & 8.3 & 7.8 & 6.9 & 7.5 & 7.8 & 8.2 \\
\hline C. Tailored Tests & & & & & & & & & & & \\
\hline C1. Combined contingent liabilities & 9.0 & 10.5 & 13.2 & 8.7 & 19.6 & 7.5 & 7.0 & 6.3 & 6.5 & 6.8 & 7.2 \\
\hline C2. Natural disaster & n.a. & n.a. & n.a. & n.a. & n.a. & n.a. & n.a. & n.a. & n.a. & n.a. & n.a. \\
\hline $\begin{array}{l}\text { C3. Commodity price } \\
\text { C4. Market Financing }\end{array}$ & n.a. & n.a. & n.a. & n.a. & n.a. & n.a. & n.a. & n.a. & n.a. & n.a. & n.a. \\
\hline Threshold & 21 & 21 & 21 & 21 & 21 & 21 & 21 & 21 & 21 & 21 & 21 \\
\hline & rvice-to- & revenue & ratio & & & & & & & & \\
\hline Baseline & 10.5 & 12.3 & 15.8 & 10.1 & 23 & 8.9 & 8.5 & 7.7 & 8.2 & 8.7 & 9.3 \\
\hline A. Alternative Scenarios & & & & & & & & & & & \\
\hline A1. Key variables at their historical averages in 2019-2039 1/ & 10.5 & 12.5 & 16.4 & 10.9 & 25.8 & & 10.2 & 9.6 & 10.7 & 11.8 & 13.1 \\
\hline B. Bound Tests & & & & & & & & & & & \\
\hline B1. Real GDP growth & 10.5 & 12.8 & 17.1 & 11.0 & 25.5 & & 9.2 & 8.3 & 8.8 & 9.4 & 10.1 \\
\hline B2. Primary balance & 10.5 & 12.3 & 16.1 & 10.7 & 24.1 & & 9.0 & 8.2 & 8.7 & 9.3 & 9.9 \\
\hline B3. Exports & 10.5 & 12.3 & 16.1 & 10.8 & 24.2 & & 9.0 & 8.1 & 8.9 & 9.9 & 10.4 \\
\hline B4. Other flows $2 /$ & 10.5 & 12.3 & 16.1 & 10.6 & 24.0 & & 8.9 & 8.0 & 8.9 & 9.6 & 10.2 \\
\hline B6. One-time 30 percent nominal depreciation & 10.5 & 15.6 & 20.0 & 12.4 & 29.4 & & 10.4 & 9.4 & 10.1 & 10.1 & 11.0 \\
\hline B6. Combination of B1-B5 & 10.5 & 13.0 & 17.5 & 11.3 & 25.9 & & 9.5 & 8.6 & 9.5 & 9.9 & 10.6 \\
\hline C. Tailored Tests & & & & & & & & & & & \\
\hline C1. Combined contingent liabilities & 10.5 & 12.3 & 16.0 & 10.4 & 23.9 & & 8.8 & 8.0 & 8.4 & 8.9 & 9.6 \\
\hline C2. Natural disaster & n.a. & n.a. & n.a. & n.a. & n.a. & n.a. & n.a. & n.a. & n.a. & n.a. & n.a. \\
\hline C3. Commodity price & n.a. & n.a. & n.a. & n.a. & n.a. & n.a. & n.a. & n.a. & n.a. & n.a. & n.a. \\
\hline C4. Market Financing & \#DIV/O! & \#DIV/O! & \#DIV/O! & \#DIV/O! & \#DIV/O! & & \#DIV/O! & \#DIV/O! & \#DIV/O! & \#DIV/O! & \#DIV/O! \\
\hline Threshold & 23 & 23 & 23 & 23 & 23 & & 23 & 23 & 23 & 23 & 23 \\
\hline
\end{tabular}


Table 4. Rwanda: Sensitivity Analysis for Key Indicators of Public Debt, 2019-29

(In percent)

\begin{tabular}{|c|c|c|c|c|c|c|c|c|c|c|c|}
\hline & \multicolumn{11}{|c|}{ Projections } \\
\hline & 2019 & 2020 & 2021 & 2022 & 2023 & 2024 & 2025 & 2026 & 2027 & 2028 & 2029 \\
\hline \multicolumn{12}{|c|}{ PV of Debt-to-GDP Ratio } \\
\hline Baseline & 42.5 & 42.9 & 42.7 & 41.6 & 41.2 & 41.0 & 40.9 & 41.1 & 41.4 & 41.8 & 42.2 \\
\hline \multicolumn{12}{|l|}{ A. Alternative Scenarios } \\
\hline A1. Key variables at their historical averages in 2019-2039 1/ & 43 & 42 & 41 & 40 & 39 & 38 & 38 & 37 & 37 & 37 & 36 \\
\hline \multicolumn{12}{|l|}{ B. Bound Tests } \\
\hline B1. Real GDP growth & 43 & 45 & 48 & 47 & 48 & 48 & 49 & 50 & 51 & 52 & 54 \\
\hline B2. Primary balance & 43 & 44 & 46 & 45 & 44 & 44 & 43 & 43 & 44 & 44 & 44 \\
\hline B3. Exports & 43 & 44 & 47 & 46 & 45 & 45 & 44 & 45 & 45 & 45 & 45 \\
\hline B4. Other flows $2 /$ & 43 & 45 & 46 & 45 & 44 & 44 & 44 & 44 & 44 & 44 & 44 \\
\hline B6. One-time 30 percent nominal depreciation & 43 & 48 & 45 & 42 & 40 & 38 & 37 & 36 & 35 & 35 & 34 \\
\hline B6. Combination of B1-B5 & 43 & 42 & 44 & 42 & 42 & 42 & 41 & 41 & 42 & 42 & 42 \\
\hline \multicolumn{12}{|l|}{ C. Tailored Tests } \\
\hline C1. Combined contingent liabilities & 43 & 47 & 46 & 45 & 44 & 44 & 43 & 44 & 44 & 44 & 44 \\
\hline C2. Natural disaster & n.a. & n.a. & n.a. & n.a. & п.а. & n.a. & n.a. & n.a. & n.a. & n.a. & n.a. \\
\hline C3. Commodity price & n.a. & п.а. & n.a. & n.a. & п.а. & n.a. & n.a. & n.a. & n.a. & n.a. & n.a. \\
\hline C4. Market Financing & 43 & & & & & & & & & & \\
\hline Public debt benchmark & 70 & 70 & 70 & 70 & 70 & 70 & 70 & 70 & 70 & 70 & 70 \\
\hline \multicolumn{12}{|c|}{ PV of Debt-to-Revenue Ratio } \\
\hline Baseline & 184.3 & 193.7 & 197.6 & 189.0 & 185.4 & 185.0 & 185.2 & 186.5 & 188.0 & 189.7 & 191.6 \\
\hline
\end{tabular}

A. Alternative Scenarios

A1. Key variables at their historical averages in 2019-2039 1/

$\begin{array}{lllllllllll}184 & 189 & 189 & 179 & 175 & 171 & 168 & 167 & 165 & 164 & 163\end{array}$

B. Bound Tests

B1. Real GDP growth

B2. Primary balance

B3. Exports

B4. Other flows 2/

B6. One-time 30 percent nominal depreciation

B6. Combination of B1-B5

C. Tailored Tests

C1. Combined contingent liabilities

C2. Natural disaster

C3. Commodity price

C4. Market Financing

$\begin{array}{lllllllllll}184 & 202 & 218 & 213 & 213 & 216 & 220 & 225 & 231 & 236 & 241 \\ 184 & 199 & 213 & 203 & 198 & 197 & 196 & 197 & 198 & 199 & 200 \\ 184 & 201 & 218 & 208 & 203 & 202 & 201 & 202 & 202 & 203 & 203 \\ 184 & 203 & 214 & 204 & 200 & 199 & 198 & 199 & 200 & 200 & 201 \\ 184 & 218 & 211 & 195 & 182 & 176 & 170 & 166 & 162 & 159 & 157 \\ 184 & 192 & 202 & 193 & 189 & 188 & 187 & 188 & 189 & 190 & 192 \\ & & & & & & & & & & \\ 184 & 211 & 213 & 203 & 198 & 197 & 197 & 197 & 198 & 199 & 201 \\ \text { n.a. } & \text { n.a. } & \text { n.a. } & \text { n.a. } & \text { n.a. } & \text { n.a. } & \text { n.a. } & \text { n.a. } & \text { n.a. } & \text { n.a. } & \text { n.a. } \\ \text { n.a. } & \text { n.a. } & \text { n.a. } & \text { n.a. } & \text { n.a. } & \text { n.a. } & \text { n.a. } & \text { n.a. } & \text { n.a. } & \text { n.a. } & \text { n.a. } \\ 184 & & & & & & & & & & \end{array}$

Debt Service-to-Revenue Ratio

\section{Baseline}

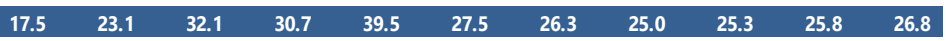

A. Alternative Scenarios

A1. Key variables at their historical averages in 2019-2039 1/

B. Bound Tests

B1. Real GDP growth

B2. Primary balance

B3. Exports

B4. Other flows 2/

B6. One-time 30 percent nominal depreciation

B6. Combination of B1-B5

C. Tailored Tests

C1. Combined contingent liabilities

C2. Natural disaster

C3. Commodity price

C4. Market Financing

Sources: Country authorities; and staff estimates and projections.

1/ Variables include real GDP growth, GDP deflator and primary deficit in percent of GDP.

2 / Includes official and private transfers and FDI. 


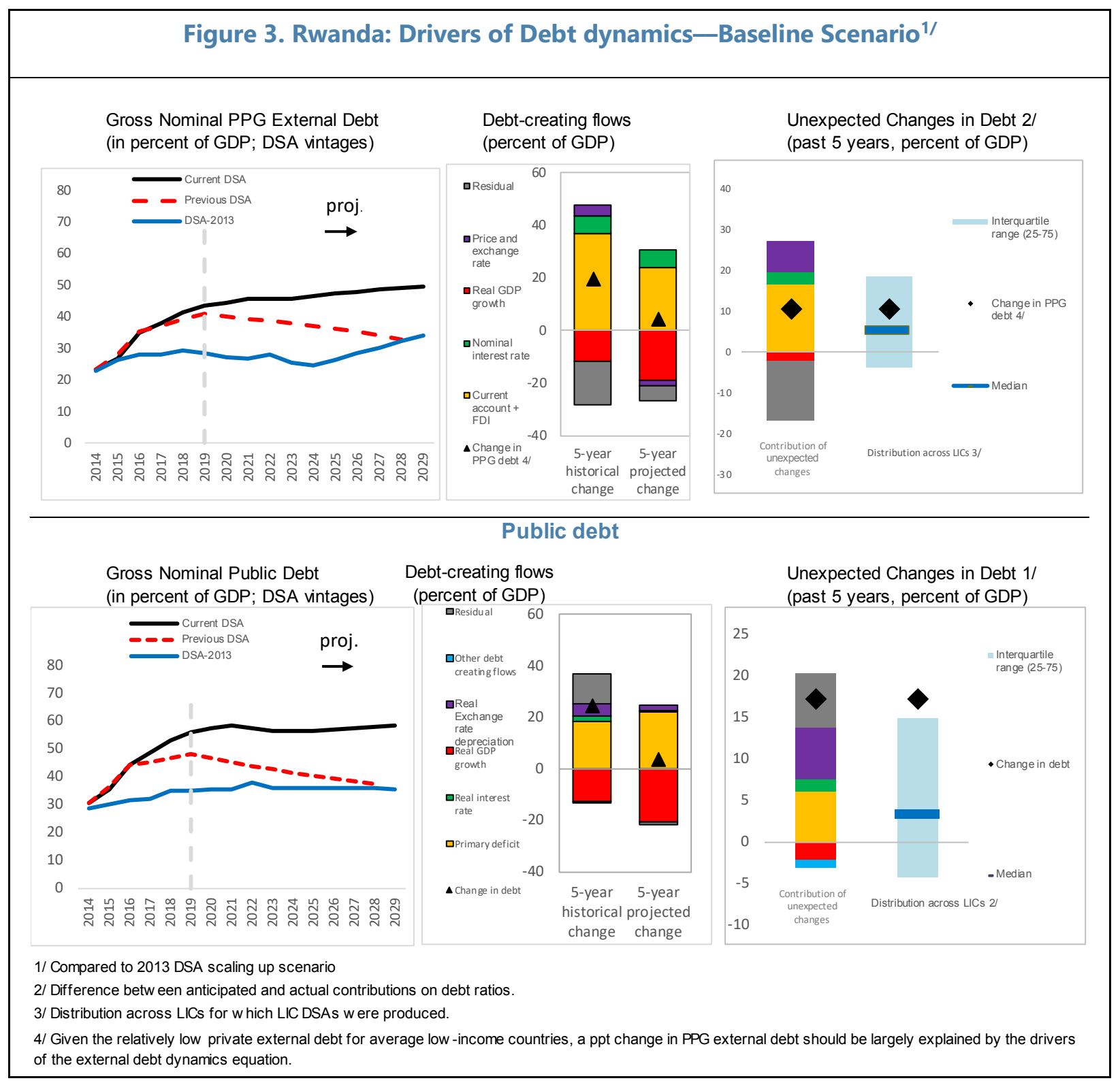


Figure 4. Rwanda: Realism Tools

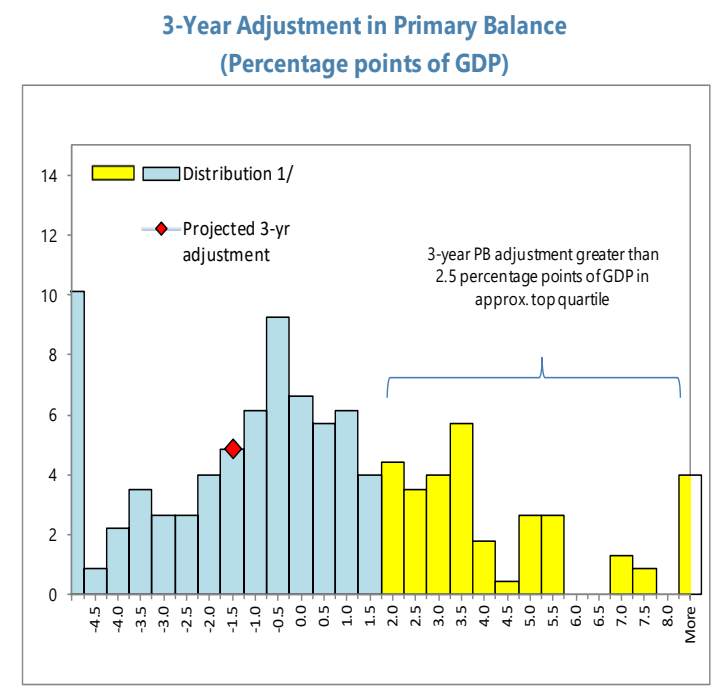

1/ Data cover Fund-supported programs for LICs (excluding emergency financing) approved since 1990. The size of 3-year adjustment from program inception is found on the horizontal axis; the percent of sample is found on the vertical axis.

Public and Private Investment Rates (\% of GDP)

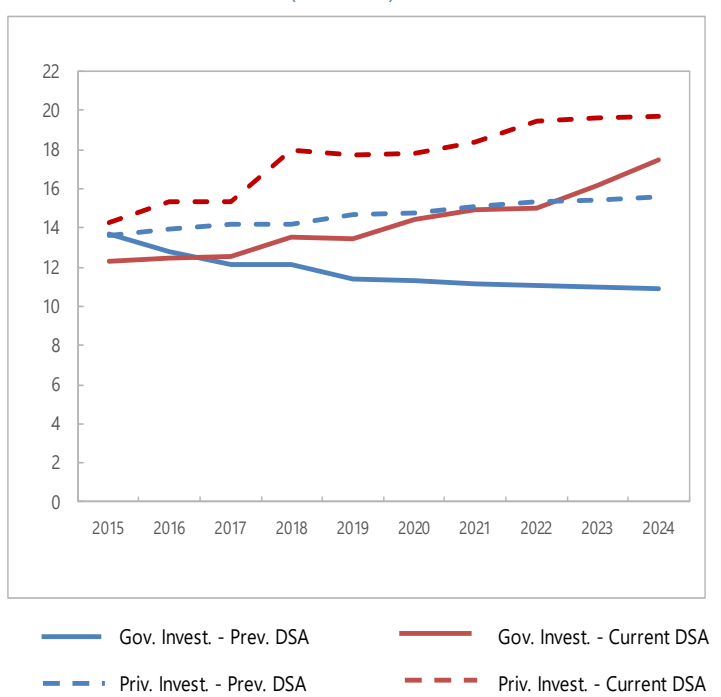

Fiscal Adjustment and Possible Growth Paths 1/

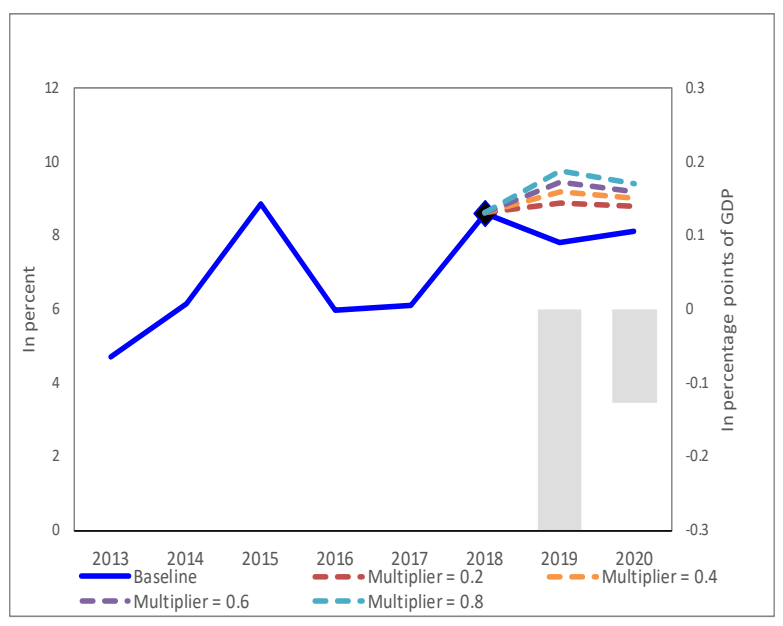

1/ Bars refer to annual projected fiscal adjustment (right-hand side scale) and lines show possible real GDP growth paths under different fiscal multipliers (left-hand side scale).

Contribution to Real GDP growth (percent, 5-year average)

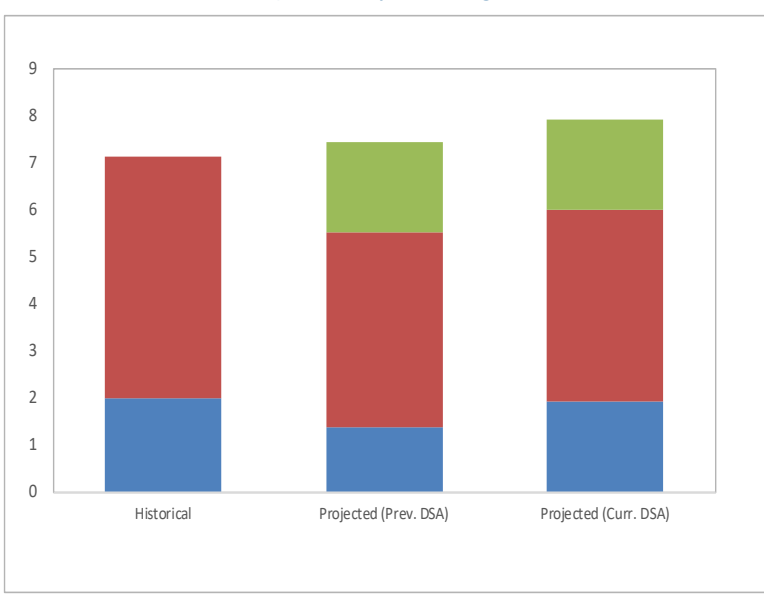

Contribution of other factors

Contribution of government capital

Bugesera effect 
Figure 5. Rwanda: Market Financing Risk Indicators

\begin{tabular}{|lcr|}
\hline & GFN $1 /$ & EMBI 2/ \\
Benchmarks & 14 & 570 \\
Values & 12 & 407 \\
Breach of benchmark & No & No \\
& & \\
Potential heightened & & \\
liquidity needs & Low & \\
\hline
\end{tabular}

1/ Maximum gross financing needs (GFN) over 3-year baseline projection horizon.

2/ EMBI spreads correspond to the latest available data.
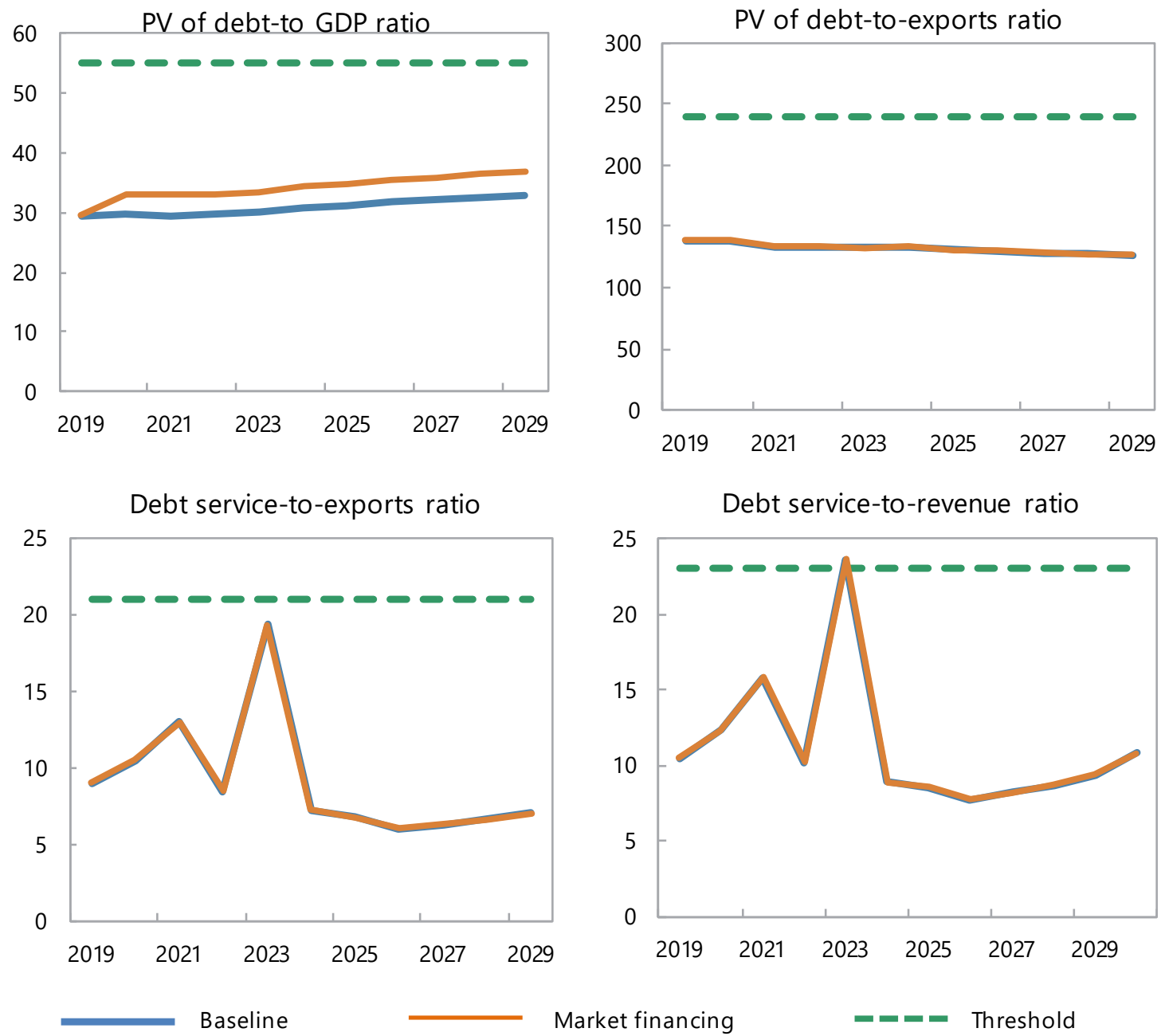

Sources: Country authorities; and staff estimates and projections. 
Figure 6. Rwanda: Indicators of Public and Publicly Guaranteed External Debt Under Customized Scenarios ${ }^{1 /}$

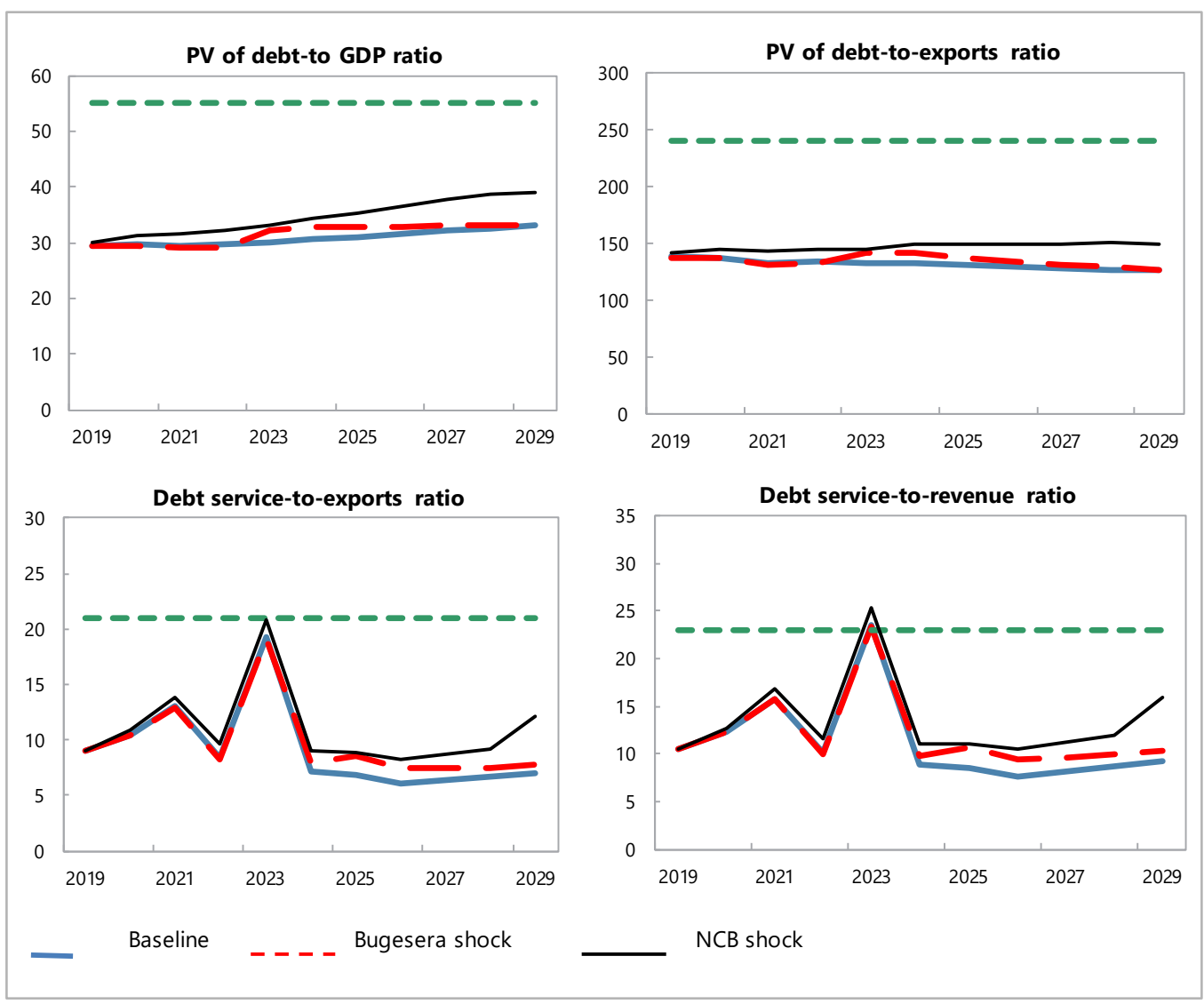

1/ Bugesera shock assumes the government is required to take on the remaining financial liability for the Bugesera airport (total $\$ 397.5 \mathrm{~m}$ ) in 2024. NCB (Non-Concessionary Borrowing) shock constitutes a scenario in which all additional external borrowing due to the new fiscal anchor is financing on commercial Eurobond terms. 


\section{INTERNATIONAL MONETARY FUND}

\section{RWANDA}

STAFF REPORT FOR THE 2019 ARTICLE IV CONSULTATION

June 11, 2019 AND REQUEST FOR A THREE-YEAR POLICY COORDINATION INSTRUMENT-INFORMATIONAL ANNEX

$\begin{array}{ll}\text { Prepared By } & \text { The African Department } \\ \text { (in consultation with other departments). }\end{array}$

\section{CONTENTS}

FUND RELATIONS $\underline{2}$

RELATIONS WITH OTHER INTERNATIONAL FINANCIAL INSTITUTIONS $\underline{2}$

STATISTICAL ISSUES $\underline{3}$ 


\title{
FUND RELATIONS
}

Rwanda and the IMF: https://www.imf.org/en/Countries/RWA

Rwanda's Financial Position in the Fund:

https://www.imf.org/external/np/fin/tad/exfin2.aspx?memberKey1=820\&date1 key=2099-12-31

\section{Exchange Rate Arrangement:}

The currency of Rwanda is the Rwandan franc. On December 1998, Rwanda accepted the obligations under Article VIII, Sections 2, 3, and 4 of the IMF and maintains a system free of multiple currency practices and restrictions on the making of payments and transfers for current international transactions. As of April 30, 2019, the exchange rate against the US dollar was RWF 892. From end-July 2017 to end-April 2019, the exchange rate has depreciated 7.2 percent against the US dollar, appreciated 5.1 percent in NEER terms, and depreciated 13 percent in REER terms. Based on the 2018 Annual Report on Exchange Arrangements and Exchange Restrictions, the de facto exchange rate regime has been classified as a "crawl-like" arrangement while the de jure exchange rate regime is floating.

\section{Safeguards Assessment}

The most recent safeguards assessment of the Banque Nationale du Rwanda (BNR) was finalized in 2016. Previous assessments were completed in 2007 and 2003. The 2016 update assessment found that the BNR had strengthened its safeguards framework and all safeguards recommendations have since been implemented. The BNR Act was amended in 2017 with enhanced provisions on personal autonomy of Board members. External audit arrangements have been strengthened and transparency of the IFRS financial statements improved. The composition of the Audit and Risk Committee was reinforced, and the internal audit and risk management functions enhanced.

\section{RELATIONS WITH OTHER INTERNATIONAL FINANCIAL INSTITUTIONS}

\author{
Rwanda and the World Bank:
}

http://www.worldbank.org/en/country/rwanda

World Bank Projects:

http://projects.worldbank.org/search?lang=en\&searchTerm =\&countrycode exact=RW

\section{Rwanda and the African Development Bank:}

https://www.afdb.org/en/countries/east-africa/rwanda/ 


\section{STATISTICAL ISSUES}

\section{Assessment of Data Adequacy for Surveillance}

General: Data provision has some shortcomings; but is broadly adequate for surveillance (case B). The quality of national accounts, government finance and monetary statistics is high in Rwanda and the country makes good use of technical assistance support from the IMF. The country has one of the most frequent base year updates among SSA countries and coordinates the base year update with a new household survey to get a better sense of home production and the informal sector. The Data Readiness Assessment in 2013 showed Rwanda's potential in delivering a successful data innovation industry indicating complementary factors already in place including good governance, ICT infrastructure development, and huge data repositories across Government institutions. This strategic vision is well enshrined into most national development policies including the Economic Development and Poverty Reduction Strategy (EDPRS II) and specifically the SMART Rwanda Master plan. All these strategies outline how Information and ICT has enormous potential in extending access to data hence to information which contributes to spur innovation and creativity, increase the proliferation of high skilled jobs, contribute to economic growth, enable better decision making and create a more accountable-efficient and effective government. The NISR is responsible for implementing the data revolution policy alongside other development partners, to be executed from 2017 to 2022.

National Accounts and Price Statistics: Annual and quarterly GDP estimates in current and 2014 constant prices are compiled and disseminated by NISR, based on the 2008 System of National Accounts concepts. Commendable efforts have been made to improve the GDP estimates, with technical assistance being provided by the East AFRITAC and DFID. NISR has been disseminating quarterly GDP estimates from 2010 and released the latest estimates consistent with the 2014 base year revision in March 2017. Preparatory work has already begun to rebase to 2017 by March 2020.

Annual agricultural surveys have recently been introduced making use of GPS territory data and this should help improve agricultural production estimates over time.

The latest Integrated Household Living Conditions Survey (EICV 5) data from October 2016 to October 2017 was released on December 2018.

The absence of a comprehensive economy-wide business survey precludes a reliable benchmark of economic activities in the private sector. Proxy indicators such as monthly VAT turnover data cover the formal sector and financial data reported by a limited number of large companies are used to estimate the production.

On the expenditure side, estimates of government consumption, gross capital formation, and trade in goods and services are compiled from data sources including government budget reports and balance of payment estimates, but private consumption and changes in inventories are estimated as the gap between the sum of these components and a total GDP estimate from the production approach. Recent East AFRITAC TA has helped to broaden national accounts outputs by developing experimental institutional sector accounts for production and the generation of income. 
Timelines of the Producer Price Index (PPI) needs improvement. The authorities also need to progress on the coverage and methodology of the production index.

Government Finance Statistics: Rwanda is transitioning to GFSM 2014 to meet EAC requirements. The authorities' nearly complete efforts to automate IFMS to produce annual and high-frequency GFSM 2014-compliant data for all Budgetary Central Government (BCG), most Extra-Budgetary Units (EBUs), and all Local Governments (LGs) on a timely basis. However, efforts should continue to add remaining EBUs, Social Security Funds (SSFs), and development projects to IFMS, and to finalize bridging from a GFSM 1986 to a GMFS 2014 framework.

Monetary and Financial Statistics: The balance sheet of the BNR and detailed data on money market transactions are transmitted to AFR on a weekly basis with a lag of one week, while the monetary survey and the consolidated balance sheet of commercial banks are transmitted on a monthly basis with a lag of about five weeks. The BNR reports to STA monthly monetary data, using Standardized Report Forms for the central bank and Other Depository Corporations (ODCs), which are published in the International Financial Statistics. Rwanda reports data on several key series and indicators of the Financial Access Survey (FAS), including mobile money and the two indicators adopted by the UN to monitor Target 8.10.1 of the Sustainable Development Goals (SDGs).

Financial Sector Surveillance: The BNR reports quarterly Financial Soundness Indicators (FSIs) to STA for publication on the IMF's FSI webpage, including all core indicators and 8 encouraged indicators for deposit takers. However, reporting is not timely, as the latest data refer to $2018 \mathrm{Q} 2$.

Balance of Payments: The BNR compiles annual balance of payments statistics based on the sixth edition of the Balance of Payments and International Investment Position Manual (BPM6) presentation. The Foreign Private Capital Survey (FPC) is used to collect flows, positions, and income data in an integrated survey instrument for both financial assets and liabilities. Direct investment liabilities are to be well measured, in part because they are sourced from the Rwanda Development Board (RDB).

On remittances, data are available for formal transfers through banks and Money Transfer Operators (MTOs) but informal estimates are less reliable and are being cross-checked with the 2011 Integrated Living Costs Survey.

The coverage of external aid remains a cause of concern. Data produced by the CEPEX does not include offshore payments, direct payments to contractors, and technical assistants, nor does it capture aid from important UN agencies and from certain countries. Only the external aid registered in the Government budget is fully covered. Concerning the NGO sector, the data should result from the survey of NGOs, but its coverage is insufficient. Many series are inconsistent with the counterpart data in the financial account of the balance of payments, have multiple misclassifications, are not in line with other macroeconomic statistics, or have no consistency across the time series.

Databases on external public debt are maintained by both MINECOFIN and the NBR. 


\section{Data Standards and Quality}

Rwanda has subscribed to the GDDS since 2009 and e-GDDS on September 22, 2017. The authorities aim to subscribe to SDDS by 2021 . Among others this would improvements in coverage, periodicity and timelines on various indicators including industrial production index, labor force statistics, and producer price index and external sector statistics.

The quality of the national accounts data in Rwanda is one of the highest in Sub-Saharan Africa with annual agricultural surveys now well integrated into the calculation of output. The updating of base years is also done on a frequent basis and household survey releases are now more frequent than any other country in SubSaharan Africa. 


\begin{tabular}{|c|c|c|c|c|c|c|c|}
\hline \multicolumn{8}{|c|}{ Table of Common Indicators Required for Surveillance, May 28, 2019} \\
\hline & \multirow{2}{*}{$\begin{array}{l}\text { Date of Latest } \\
\text { Observation }\end{array}$} & \multirow{2}{*}{$\begin{array}{c}\text { Date } \\
\text { Received }\end{array}$} & \multirow{2}{*}{$\begin{array}{l}\text { Frequency } \\
\text { of Data }{ }^{7 /}\end{array}$} & \multirow{2}{*}{$\begin{array}{l}\text { Frequency } \\
\text { of } \\
\text { Reporting }\end{array}$} & \multirow{2}{*}{$\begin{array}{c}\text { Frequency } \\
\text { of } \\
\text { Publication }\end{array}$} & \multicolumn{2}{|c|}{ Memo Items:8/ } \\
\hline & & & & & & $\begin{array}{l}\text { Data Quality - } \\
\text { Methodological } \\
\text { Soundness }\end{array}$ & $\begin{array}{l}\text { Data Quality - } \\
\text { Accuracy and } \\
\text { Reliability }^{10 /}\end{array}$ \\
\hline Exchange rate & $4 / 30 / 19$ & $5 / 1 / 19$ & $D, M$ & $\mathrm{D}, \mathrm{M}$ & $D, M$ & & \\
\hline International Reserve Assets and & $4 / 30 / 19$ & $5 / 3 / 19$ & $D, M$ & $D, M$ & $M$ & & \\
\hline Reserve Liabilities of the Monetary & & & & & & & \\
\hline Authorities ${ }^{1 /}$ & & & & & & & \\
\hline Reserve/Base Money & $4 / 30 / 19$ & $5 / 3 / 19$ & $\mathrm{D}, \mathrm{M}$ & $\mathrm{D}, \mathrm{M}$ & M & & \\
\hline Broad Money & $3 / 31 / 19$ & $5 / 9 / 19$ & M & M & M & & \\
\hline Central Bank Balance Sheet & $3 / 31 / 19$ & $5 / 9 / 19$ & $\mathrm{D}$ & $\mathrm{D}$ & $\mathrm{D}$ & $\mathrm{LO}, \mathrm{LO}, \mathrm{LO}, \mathrm{LO}$ & $\mathrm{LO}, \mathrm{O}, \mathrm{O}, \mathrm{O}, \mathrm{LO}$ \\
\hline Consolidated Balance Sheet & $3 / 31 / 19$ & $5 / 9 / 19$ & M & M & M & & \\
\hline of the Banking System & & & & & & & \\
\hline Interest Rates ${ }^{2 /}$ & $3 / 31 / 19$ & $5 / 9 / 19$ & M & M & M & & \\
\hline Consumer Price Index & $4 / 30 / 19$ & $5 / 10 / 19$ & M & M & M & $\mathrm{O}, \mathrm{LO}, \mathrm{O}, \mathrm{LO}$ & LNO, LNO, \\
\hline $\begin{array}{l}\text { Revenue, Expenditure, Balance and } \\
\text { Composition of Financing } 3 / \text {-_ }\end{array}$ & $12 / 31 / 18$ & $3 / 9 / 19$ & Q & Q & Q & & \\
\hline General Government ${ }^{4 /}$ & & & & & & LNO, LNO, & LO, O, O, LO, O \\
\hline $\begin{array}{l}\text { Revenue, Expenditure, Balance and } \\
\text { Composition of Financing }{ }^{3 /}-\end{array}$ & $12 / 31 / 18$ & $3 / 9 / 19$ & Q & Q & Q & LNO, LO & $L U, U, U, L U, U$ \\
\hline Central Government & & & & & & & \\
\hline Stocks of Central Government & $12 / 31 / 18$ & $3 / 12 / 19$ & Q & Q & Q & & \\
\hline $\begin{array}{l}\text { and Central Government- } \\
\text { Guaranteed Debt }{ }^{5 /}\end{array}$ & & & & & & & \\
\hline External Current Account & $12 / 31 / 18$ & $3 / 11 / 19$ & A & A & A & & LO, LNO, O, \\
\hline Balance & & & & & & LU, LU, LU, LU & LNO, LNO \\
\hline $\begin{array}{l}\text { Exports and Imports of Goods and } \\
\text { Services }\end{array}$ & $3 / 31 / 19$ & $5 / 9 / 19$ & M & $\mathrm{M}$ & M & & \\
\hline
\end{tabular}




\begin{tabular}{|c|c|c|c|c|c|c|c|}
\hline \multicolumn{8}{|c|}{ Table of Common Indicators Required for Surveillance, May 28, 2019 (Concluded) } \\
\hline & \multirow{2}{*}{\begin{tabular}{|c|} 
Date of Latest \\
Observation
\end{tabular}} & \multirow{2}{*}{$\begin{array}{c}\text { Date } \\
\text { Received }\end{array}$} & \multirow{2}{*}{$\begin{array}{l}\text { Frequency } \\
\text { of Data }\end{array}$} & \multirow{2}{*}{$\begin{array}{l}\text { Frequency } \\
\text { of } \\
\text { Reporting }\end{array}$} & \multirow{2}{*}{$\begin{array}{l}\text { Frequency of } \\
\text { Publication }^{7}\end{array}$} & \multicolumn{2}{|c|}{ Memo Items: ${ }^{8 /}$} \\
\hline & & & & & & $\begin{array}{l}\text { Data Quality - } \\
\text { Methodologic } \\
\text { al Soundness }{ }^{9 /}\end{array}$ & $\begin{array}{l}\text { Data Quality - } \\
\text { Accuracy and } \\
\text { Reliability }{ }^{10 /}\end{array}$ \\
\hline GDP/GNP & $\begin{array}{c}\text { March } 19(\mathrm{~A}) \\
3 / 15 / 19(\mathrm{Q})\end{array}$ & $\begin{array}{l}\text { March } 19 \\
03 / 15 / 19\end{array}$ & $\mathrm{Q}, \mathrm{A}$ & $Q, A$ & $Q, A$ & LO, LO, LO, LO & $\begin{array}{l}\text { LNO, LNO, O, } \\
\quad \text { LO, LO }\end{array}$ \\
\hline Gross External Debt & $12 / 31 / 18$ & $3 / 13 / 19$ & M & M & M & & \\
\hline International Investment Position ${ }^{6 /}$ & $12 / 31 / 17$ & $5 / 9 / 18$ & $A$ & A & $A$ & & \\
\hline \multicolumn{8}{|c|}{$\begin{array}{l}\text { 1/ Any reserve assets that are pledged or otherwise encumbered should be specified separately. Also, data should comprise short-term liabilities linked to a } \\
\text { foreign currency but settled by other means as well as the notional values of financial derivatives to pay and to receive foreign currency, including those } \\
\text { linked to a foreign currency but settled by other means. }\end{array}$} \\
\hline \multicolumn{8}{|c|}{ 2/ Both market-based and officially-determined, including discount rates, money market rates, rates on treasury bills, notes and bonds. } \\
\hline \multicolumn{8}{|c|}{ 3/ Foreign, domestic bank, and domestic nonbank financing. } \\
\hline \multicolumn{8}{|c|}{$\begin{array}{l}{ }^{4 /} \text { The general government consists of the central government (budgetary funds, extra budgetary funds, and social security funds) and state and local } \\
\text { governments. }\end{array}$} \\
\hline \multicolumn{8}{|c|}{ 5/ Including currency and maturity composition. } \\
\hline \multicolumn{8}{|c|}{ 6/ Includes external gross financial asset and liability positions vis-à-vis nonresidents. } \\
\hline \multicolumn{8}{|c|}{ 7/ Daily (D); weekly (W); monthly (M); quarterly (Q); annually (A); irregular (I); and not available (NA). } \\
\hline \multicolumn{8}{|c|}{ 8/ These columns should only be included for countries for which Data ROSC (or a Substantive Update) has been published. } \\
\hline \multicolumn{8}{|c|}{$\begin{array}{l}\text { 9/ This reflects the assessment provided in the data ROSC or the Substantive Update (published on March 12, } 2004 \text { and based on the findings of the mission } \\
\text { that took place during October 8-22, 2002) for the dataset corresponding to the variable in each row. The assessment indicates whether international } \\
\text { standards concerning concepts and definitions, scope, classification/sectorization, and basis for recording are fully observed (O); largely observed (LO); largely } \\
\text { not observed (LNO); not observed (NO); and not available (NA). }\end{array}$} \\
\hline 0/ Same as footnote 7, except referring & ternational st & dards cor & g (respe & y) source $d$ & sessment of & & \\
\hline
\end{tabular}




\section{Statement by the Executive Director, Mr. Mohamed-Lemine Raghani and the Advisor of the Executive Director, Ms. Loy Nankunda on Rwanda June 28, 2019}

Our Rwandan authorities would like to express their gratitude to Staff, Management and the Executive Board for the Fund's continued support to their policy and reform agenda. They value the close cooperation with the Fund and appreciate the constructive discussions held with staff in Kigali in the context of the 2019 Article IV Consultation and the negotiations for the Policy Coordination Instrument (PCI).

Amid a challenging environment and exposure to exogenous shocks, Rwanda's economic performance continues to be strong thanks to the authorities' commitment to reforms and ownership of their development agenda. Growth has been sustained and inclusive over the past years, economic transformation is taking hold and important inroads have been made in poverty reduction. The significant economic and social gains of the last decade have been achieved with the IMF support.

Looking ahead, the authorities are strongly committed to transforming Rwanda into an upper middle-income economy by 2035. To achieve this objective, they will implement their National Strategy for Transformation (NST). The first plan of this kind, NST1, spans over the 2017-24 period and emphasizes the main three pillars of economic transformation, social transformation and transformational governance.

It is in this context that the Rwandan authorities request a successor program supported by a PCI. They broadly agree with staff analysis on the recent developments, outlook and risks as well as policy priorities to sustain the implementation of their economic transformation agenda. The PCI is intended to support progress towards the NST1 objectives, including by helping to preserve fiscal discipline, improve domestic revenue mobilization and maintain debt sustainability.

\section{Recent Developments and Outlook}

Real GDP growth accelerated to 8.6 percent in 2018, exceeding projections, mainly driven by activity in construction, manufacturing and trade and transport services. Inflation stood at 1.4 percent on average in 2018, well below the authorities' medium-term target of 5 percent. It fell further to 0.2 percent $y-0-y$ in April 2019. It is against this background that the National Bank of Rwanda (NBR) lowered its policy rate from 5.5 percent to 5.0 percent last May. The fiscal position in 2018, with an overall deficit of 4.7 percent of GDP, was broadly similar to the previous year and in line with expectations. The current account deficit of 7.9 percent of GDP was broadly unchanged from 2017. Gross international reserves improved slightly from 4.5 to 4.6 months of prospective imports. 
The medium-term outlook remains favorable. Growth is projected to stand around 8 percent over the medium-term while inflation is expected to be within the target band. The current account deficit would rise to 9.6 percent in 2019 and decline thereafter, reflecting frontloaded public investment spending, consistent with meeting NST1 targets. Its financing will continue to rely on private direct investment and bilateral and multilateral infrastructure project loans. The authorities will further enhance economic resilience and build up buffers to mitigate the effects of downside risks, notably lower-than-projected official development assistance (ODA), adverse commodity price shocks and difficult weather conditions - if they came to materialize.

\section{Macroeconomic Policies and Reforms for 2019 and the Medium Term}

Building on the progress achieved thus far, the Rwandan authorities will pursue sound and supportive macroeconomic policies and implement key reforms for 2019 and the medium term. In this regard, they have adopted new fiscal and monetary policy frameworks and put in place an ambitious reform agenda to strengthen public financial management (PFM), foster financial sector development, and buttress private sector development. They are committed to keeping the reform momentum for addressing the economy's remaining challenges while making further steps in implementing their National Strategy for Transformation.

\section{Fiscal Policy and Reforms}

The authorities' fiscal policy will be geared towards promoting higher and inclusive growth while ensuring fiscal and debt sustainability. In this respect, they will strive to maintain the public debt-to-GDP ratio in present value below 50 percent over the medium term and to preserve the country's low risk of debt distress. Fiscal policy beginning FY 2019/20 onwards will target an overall fiscal deficit of no more than 5.5 percent of GDP on a five-year rolling basis. This will create fiscal space to contribute to the financing of the NST1.

The authorities fully understand the criticality of boosting domestic revenue to support their transformation agenda. They will make steps to raise domestic revenue on average by 0.2 percentage point of GDP annually over the medium term starting in FY 2020/21. In this regard, they are committed to refining their tax expenditure framework including for streamlining tax exemptions and improving tax compliance. They are also taking measures to further strengthen tax administration, such as leveraging various digital technologies to reinforce risk-based audits and enhance VAT refunds.

Public financial management will be further reinforced with reforms that are being implemented to enhance fiscal transparency and public investment management. Going forward, the authorities are committed to further reduce fiscal risks and improve transparency including by moving to the GFSM 2014 fiscal reporting framework and developing internal capacity to start conducting fiscal risk analyses, with the technical assistance of the Fund. 


\section{Monetary and Exchange Rate Policies}

The NBR has transitioned to the new interest rate-based monetary policy framework. The latter is supplemented by new infrastructure and efforts to bolster liquidity management, enhance communication and deepen money and financial markets. The central bank will strive to keep inflation within the target band going forward to prevent the entrenchment of low inflation expectations. Moreover, measures have been introduced to develop the interbank markets and to supplement the NBR's forecasting capacity and market expectation surveys.

The authorities will maintain their flexible exchange rate regime as the first line of defense against external shocks. They will also continue supplying foreign exchange to the market to satisfy demand reflecting mostly the execution of infrastructure projects, while considering the implications for financial sector and price stability. The current level of gross international reserves at 4.5 months of prospective imports is comfortable for precautionary purposes.

\section{Financial Sector Policies}

The financial sector remains sound and stable, with adequate liquidity, profitability and capitalization. The financial regulatory and supervisory frameworks are broadly aligned with international standards. Updated standards on disclosure and regulatory reporting have been implemented. The authorities will endeavor to further strengthen the AML/CFT framework along the lines recommended by an IMF technical assistance mission. In this regard, they have developed several offsite and onsite AML/CFT supervisory tools which will be strengthened based on a new law adopted in August 2018. They also continue to collect data on institutions presenting money laundering/terrorist financing risks.

\section{Structural Reforms}

The authorities are committed to advancing economic diversification and structural transformation to realize growth potential. They will strive to lift related impediments to promote a private sector-led, job-rich and inclusive growth at the core of their NTS1. Continuous progress in improving the business environment is of paramount importance in this strategy. Remarkable achievements have been made in the past decade on this front. Indeed, the World Bank's 2019 Doing Business report ranks Rwanda among the top-10 performers worldwide, with the 29th position out of 190 countries globally and 2nd position in Africa. To further improve the business climate, the authorities are stepping up efforts to bring down the costs of financing, energy and transportation.

As well, the authorities are determined to strengthen competitiveness, increase efficiency in the delivery of public and private services, advance human capital and gender equality, reform the labor market and promote regional integration. The recent coming into force of the Continental Free Trade Area (CFTA) will contribute to the authorities' effort to boost 
trade and spur broad-based growth. They will also leverage their participation in the G-20 Compact with Africa initiative and are calling on development partners to avail "blended finance".

\section{Conclusion}

The Rwandan authorities have achieved impressive results in strengthening macroeconomic stability and reforming the economy over the past decade. They recognize the challenges still lying ahead notably in terms of further improving domestic revenue mobilization and creating the fiscal space to meet their economic transformation ambitions. The authorities are committed to continue to implement their policies and reforms to boost long-term inclusive growth while sustaining macroeconomic stability. The authorities are confident that a PCI would help reach these objectives, including as a signaling tool and by catalyzing partners' support. Our authorities request the Executive Board support for a PCI. 